The Effect of Job Displacement on College Enrollment: Evidence from Ohio Veronica Minaya, Brendan Moore, and Judith Scott-Clayton

NBER Working Paper No. 27694

August 2020, Revised September 2020

JEL No. I23,J60

\begin{abstract}
Displaced workers su er large and persistent earnings losses. These losses can be mitigated by returning to school, yet the extent to which such workers enroll in post-secondary education in response to displacement is poorly understood. Using employer-employee-student matched administrative data from Ohio, we provide the rst direct evidence of workers' enrollment responses following mass layo s in the United States. Close to $10 \%$ of these displaced workers enroll in public two- or four-year colleges after displacement, with the typical enrollment persisting for ve semesters and $29 \%$ completing a degree. However, much of this enrollment may have occurred regardless of the displacement. To estimate a causal e ect, we compare displaced workers over time to similar non-displaced workers. We estimate that for every 100 displaced workers, only about 1 is ever induced to enroll in a public college as a result. This e ect is concentrated almost entirely among displaced manufacturing workers, who enroll at a rate of 2.5 per every 100. Such workers with lower within- rm earnings and from local labor markets with limited for-pro t college options are the most likely to enroll in public institutions.

Veronica Minaya

Teachers College, Columbia University

525 W. 120th St, Box 174

New York, NY 10027

vmm2122@tc.columbia.edu

Brendan Moore

Stanford University

Department of Economics

579 Jane Stanford Way

Stanford, CA 94305

bdmoore@stanford.edu

Judith Scott-Clayton

Teachers College

Columbia University

525 W.120th Street, Box 174

New York, NY 10027

and NBER

scott-clayton@tc.columbia.edu
\end{abstract}




\title{
The Effect of Job Displacement on College Enrollment:
}

\section{Evidence from Ohio}

\author{
Veronica Minaya \\ Columbia University
}

Brendan Moore

Stanford University

August 2020

\author{
Judith Scott-Clayton*
}

Columbia University and NBER

\begin{abstract}
Displaced workers suffer large and persistent earnings losses. These losses can be mitigated by returning to school, yet the extent to which such workers enroll in post-secondary education in response to displacement is poorly understood. Using employer-employee-student matched administrative data from Ohio, we provide the first direct evidence of workers' enrollment responses following mass layoffs in the United States. Close to $10 \%$ of these displaced workers enroll in public two- or four-year colleges after displacement, with the typical enrollment persisting for five semesters and $29 \%$ completing a degree. However, much of this enrollment may have occurred regardless of the displacement. To estimate a causal effect, we compare displaced workers over time to similar non-displaced workers. We estimate that for every 100 displaced workers, only about 1 is ever induced to enroll in a public college as a result. This effect is concentrated almost entirely among displaced manufacturing workers, who enroll at a rate of 2.5 per every 100 . Such workers with lower within-firm earnings and from local labor markets with limited for-profit college options are the most likely to enroll in public institutions.
\end{abstract}

Keywords: Layoffs, Plant Closings, Higher Education

JEL Classification: E24, I21, I23, J24, J63, J65

*Minaya: Minaya-Lazarte@exchange.tc.columbia.edu; Moore: bdmoore@stanford.edu; Scott-Clayton: scottclayton@tc.columbia.edu; We thank Katharine Abraham, Andrew Foote, Michel Grosz, Ben Hyman, Patrice Iatarola, Robert Kelchen, Jason Lee, Karen Ni, Christina Patterson, Jesse Rothstein, Daphne Skandalis, Jim Spletzer, Miguel Urquiola, and participants at the New York Fed Economics of Education Seminar and the Association for Education Finance and Policy Annual Conference for feedback on this paper. We gratefully acknowledge Lisa Neilson and the staff of the Ohio Education Research Center, who helped facilitate our use of the restricted data in this study. 


\section{Introduction}

Highly-tenured workers who lose their jobs in mass layoffs suffer large and persistent earnings losses many years after their initial separations. This "scarring effect" curtails earnings by 15 to $20 \%$ even two decades after displacement (Davis and Von Wachter, 2011). Community college credentials and retraining programs that specifically target displaced workers can ameliorate these losses, even for older workers and those in particularly distressed industries and regions (Jacobson, LaLonde, and Sullivan, 2005a,b; Hyman, 2018). In the absence of other constraints, such workers might seek to upskill when faced with such grim economic prospects.

Surprisingly, very few studies have attempted to directly estimate the causal effect of job displacement on postsecondary enrollment among those who were actually displaced. While prior literature has established that community college enrollment rises when the labor market is weak (Barrow and Davis, 2012; Hillman and Orians, 2013; Foote and Grosz, 2019), this is not necessarily informative regarding the effects on displaced workers themselves. Enrollment induced by poor labor markets may come primarily from individuals besides those who lost their job: workers who voluntarily leave their jobs to return to school, recent high school graduates who opt to pursue college instead of entering a weak labor market, and those whose college choices are indirectly affected via the financial situations of their parents. One paper which directly examines job displacement and subsequent postsecondary enrollment is Frenette et al. (2011). The authors use the Canadian Longitudinal Worker File to compare enrollment before and after 2003 for workers displaced in 2003 versus similar workers who were not displaced, they find that job displacement for Canadian workers age 25-44 increases postsecondary enrollment by 0.6 to 1.3 percentage points over the subsequent four years, from a baseline enrollment rate of about 10\% among a non-displaced comparison group.

It is not clear whether the findings of Frenette et al. (2011) would translate to an American setting, given the differences in UI policies, educational options, and safety net programs (Card and Riddell, 1993; Card and Oreopoulos, 2019; Jones and Riddell, 2019). For example, Barr and Turner (2015, 2018) find that specific UI policy factors influence the enrollment response of unemployed 
workers in the United States ${ }^{1}$ - among them, UI benefit duration, the ease with which UI recipients can claim benefits while enrolled, and whether agencies are proactive about informing unemployed workers of available financial aid. Further, the relative "push" of weaker labor markets and "pull" of more generous disability insurance (DI) in the U.S. compared to Canada may induce some Americans workers who would have otherwise sought retraining to instead take up DI (Milligan and Schirle, 2019). To illustrate this point, in U.S. regions that were highly exposed to Chinese import competition in the 1990s and 2000s, the per capita increase in Social Security DI payments was more than thirty times that of Trade Adjustment Assistance (TAA), the federal program which incentivizes retraining for workers displaced by foreign trade (Autor et al., 2013). For these and other reasons, it is not obvious whether Frenette et al.'s (2011) findings would generalize to an American setting. Our paper provides the first direct evidence using micro-level data of the effect of job displacement on college enrollment in the United States.

Using employer-employee-student matched administrative data from Ohio, we identify workers who lose their job in a mass layoff between 2002 and 2009 and find $9 \%$ enroll in public two- or four-year colleges after displacement. The typical enrollment spell persists for five semesters, and $29 \%$ of these displaced workers attain a degree after being laid off. However, much of this enrollment may have occurred regardless of an individual's career disruption. Using a dynamic two-way fixed effects approach similar to Jacobson, LaLonde, and Sullivan (1993), we estimate the causal effect of job displacement on postsecondary enrollment. Our preferred model includes linear worker-specific time trends in addition to worker fixed effects, and all specifications include a comparison group of non-displaced workers. We find that the enrollment response to job displacement is very small: for every 100 displaced workers, only 1 is ever induced to enroll in a public college within four years of layoff. Most of the "enrollment effect" occurs within the first year of displacement.

Our identifying assumption is that displacement is orthogonal to unobserved, non-linear trends in employment or human capital. If a worker receives a positive or negative shock that affects both postsecondary enrollment decisions and displacement, our approach will incorrectly attribute any

\footnotetext{
${ }^{1}$ The authors do not restrict their samples to highly-tenured displaced workers
} 
change in enrollment trajectories to the effect of displacement. While it is not possible to rule out every possible alternative explanation, we find that our results are robust to a range of sensitivity checks, including models that exclude the individual-specific trends, models that utilize alternative measures of enrollment, and models examining effects for shutdowns versus mass layoffs separately.

After presenting our main results, we then explore how these enrollment effects differ by industry of displacement. We show this effect is almost entirely concentrated in the manufacturing sector, which comprises just $29 \%$ of our displaced sample. Within a year of displacement, more than 2 workers per every 100 laid off from manufacturing firms enrolled in college. After three years, this effect grew to 2.5 workers. Our sample (laid off between 2002 and 2009) spans the period when U.S. manufacturing employment's decades-long decline fell at its fastest rate (Pierce and Schott, 2016), so the relative value of switching industries may be particularly high for these workers. Nevertheless, our findings suggest that even in this declining industry, few workers respond to job loss by seeking postsecondary retraining.

We then restrict our sample to manufacturing employees to explore whether heterogeneity in these effects follows the patterns we would predict based upon economic theory. First, we present evidence that a worker's likelihood of enrollment depends strongly on her income prior to layoff, specifically relative to coworkers. Because lower earners (within a firm) are typically younger and have less educational attainment, one would predict these workers may be differentially more likely to pursue schooling after displacement. Although we document that even the highest-paid displaced manufacturing employees are drawn to college after layoff, middle- and low-earners are more likely to seek retraining. For instance, three years after layoff, the displaced from the bottom-tercile of firm earnings distribution are more than three times as likely to enroll in college than those laid off from the top tercile.

Next, we examine whether a displaced workers' geographic proximity to Ohio institutions of higher education relates positively with likelihood of enrollment, consistent with economic theory (lower economic cost of enrollment for workers nearby) and past empirical evidence (Card, 1993). While proximity to a higher concentration of public colleges doesn't predict increased public enroll- 
ment, we document that enrollment in public institutions are depressed in local labor markets with a higher concentration of for-profit schools. Our study complements previous evidence that public and for-profit schools are substitutes (Laband and Lentz, 2004; Cellini, 2009; Cellini et al., 2020).

We find that other dimensions of heterogeneity do not predict a displaced worker's likelihood of college enrollment. For example, despite the fact that those laid off in the third calendar quarter (July to September) may be better-positioned to swiftly transition to college in the autumn semester compared to those displaced in the fourth quarter, we conclude that the season of one's layoff does not explain variation in subsequent enrollment. Similarly, while firm size or whether the firm closes permanently (as opposed to simply shedding workers) could theoretically influence workers post-layoff educational decisions, we detect no empirical relationship.

Our heterogeneity analysis lends credibility to our causal interpretation of the effects of job loss on enrollment. To the extent that our baseline estimates were driven by selection bias rather than a causal mechanism, we would not necessarily expect our estimation to yield these patterns of heterogeneity. Further work is needed to determine how many displaced workers retrain at private, for-profit, or non-college institutions and whether the postsecondary training programs effectively match displaced workers with new jobs. We proceed by summarizing related literature in section 2 and describing the data in section 3. Section 4 outlines the empirical strategy. Section 5 reviews our findings, and section 6 discusses and concludes.

\section{Previous Literature}

For workers displaced in mass layoffs and plant closings, the consequences of job loss are large and extend beyond when they are unemployed (Jacobson et al., 1993; Charles and Stephens, 2004; Brand et al., 2008). On average, these workers experience a $20 \%$ reduction in their earnings up to two decades after the displacement occurred (Von Wachter et al., 2009). Displaced workers are also more likely to suffer health issues, end up on the disability rolls, or die following job loss (Autor and Duggan, 2003; Sullivan and Von Wachter, 2009). The long-run earnings losses of displaced workers 
are associated with a declining demand for a certain set of job- or industry-specific skills (Jacobson et al., 2005b). Employees with specific skills in waning industries experience lower earnings even after they are reemployed full-time because their old skills are less valuable to other employers and more difficult to transfer to emerging and growing sectors (LaLonde and Sullivan, 2010).

The job displacement literature is linked to a well-developed scholarship on the impact of retraining on earnings. This literature estimates substantial returns to college and shows that it takes time for the benefits of training to be realized. In their studies, Jacobson, LaLonde, and Sullivan (2005a,b) link administrative earnings records with community college transcripts for workers displaced from their jobs in Washington State. They estimate returns to one year of college to be about $9 \%$ for men and about $13 \%$ for women. The authors also show that returns to community college for displaced workers may be limited in the short-term but increases over time. In more recent work, Hyman (2018) exploits quasi-random assignment of TAA cases to investigators of differing approval leniencies to estimate that that the program boosts earnings by $\$ 50,000$ over a decade for displaced workers through its extended unemployment benefits, job search assistance, and retraining subsidies. Finally, using a similar dataset and time period as we examine here, Leung and Pei (2020) apply a matching strategy that compares UI claimants from Ohio who enrolled in further education to similar claimants who did not. They find that enrollees earned about $7 \%$ more than non-enrollees three to four years after enrollment.

Although this research demonstrates that retraining through community colleges can reduce the skills gaps of some of these displaced workers and mitigate their earnings losses, the extent to which such workers enroll in postsecondary education in response to displacement is poorly understood. Theoretically, in the absence of other constraints, labor market downturns decrease the opportunity cost of postsecondary enrollment by reducing current labor market opportunities.

The literature studying the impact of losing one's job on educational investment has largely focused on settings with high unemployment or in a recession (Betts and McFarland, 1995; Card and Lemieux, 2001; Berger and Kostal, 2002). In a more recent study, Barr and Turner (2015) estimate the college enrollment response during the Great Recession by examining the interaction of 
labor market conditions and state-specific UI policies and how this affects postsecondary enrollment. They find that individuals in their mid to-late twenties are proportionally more responsive to cyclical variation in economic conditions and that an additional 10 weeks of UI benefits increases the likelihood of enrollment among unemployed workers by about 1.8 percentage points.

Far less attention has been devoted to the causal effect of job displacement on postsecondary enrollment among those who were actually displaced and often face especially difficult readjustments. Foote and Grosz (2019) estimate the effect of local labor market downturns measured by local mass layoff events on two-year college enrollment using aggregate data at the commuting-zone level and applying a generalized difference-in-difference approach with year and commuting-zone fixed effects. Three years after a mass layoff, they find that for every 100 workers involved, 3 enrolled in a two-year college and 2 completed a credential. While their analysis spans the entire country and includes for-profit institutions, it is conducted at the aggregate level and therefore cannot pinpoint whether individuals enrolling are the same ones who were laid off. Moreover, geographic mobility could be a confounding factor in this context, although the authors argue that the role of migration was muted during periods of labor market exits from mass layoffs (Foote et al., 2019).

Ost et al. (2018) also studied the effects of mass layoffs on educational investments, but among working college students who are already enrolled and experience a layoff while enrolled. They compare students who worked at firms that had a mass layoff in their first year enrolled to students who worked at firms that had a mass layoff in their third year enrolled. They find that layoff leads to a considerable reduction in the probability of employment while in school, but it has little impact on enrollment decisions at the extensive margin. On the intensive margin, they find that layoff leads to an increase in enrolled credits. While the authors use the same administrative data that we use in this study, their analytical sample and research question are focused on individuals who are already enrolled prior to a layoff.

Our study is most similar to Frenette et al. (2011), who exploit micro-level variation in individual job displacement and consider the impact of mass-layoff on the postsecondary enrollment of workers in the Canadian context. They find that workers affected by mass layoff events are slightly more 
likely to subsequently enroll in college compared to workers not affected by mass layoff events. Using a strategy of individual fixed effects with a control group comparing enrollment before and after 2003 for workers displaced in 2003 versus similar workers who were not displaced, they find that job displacement for Canadian workers age 25-44 increases postsecondary enrollment by 0.6 to 1.3 percentage points over the subsequent four years, from a baseline enrollment rate of about $10 \%$ among a non-displaced comparison group.

Our study is the first to use micro-level data to measure the direct effect of job displacement on college enrollment in the United States. Aided by the richness of our worker-student matched administrative data, our work is also the first to examine heterogeneity in these effects, including by industry, geography, and earnings rank within the firm.

\section{Data}

We utilize three administrative data sources from the state of Ohio to study the links between displacement and education decisions. These data are made available through the Ohio Educational Research Center (OERC), which assembles data from multiple state agencies, including the Ohio Department of Higher Education (ODHE) and the Ohio Department of Job and Family Services (ODJFS), into a repository known as the Ohio Longitudinal Data Archive (OLDA). ${ }^{2}$

The first dataset provides information for all students attending Ohio public institutions of higher education between the years 2000 and $2011 .^{3}$ The data, which aggregate student performance to the student-by-semester level, includes credits earned, institution attended, degree information, as well as demographic variables such as race, age, and gender. All schools have four semesters corresponding to winter, spring, summer and fall, with the vast majority of schools experiencing

\footnotetext{
${ }^{2}$ The Ohio Longitudinal Data Archive is a project of the Ohio Education Research Center (http://www.oerc.osu.edu/oerc.osu.edu) and provides researchers with centralized access to administrative data. The OLDA is managed by The Ohio State University's CHRR (https://chrr.osu.edu/chrr.osu.edu) in collaboration with Ohio's state workforce and education agencies (http://www.ohioanalytics.gov/ohioanalytics.gov), with those agencies providing oversight and funding. For information on OLDA sponsors, see http://chrr.osu.edu/projects/ohiolongitudinal-data-archive.

${ }^{3}$ We have data on Ohio Technical Centers (OTCs) as well, a network of noncredit career development programs operated by local educational institutions, but do not use it in our analysis because only $1 \%$ of displaced workers in our sample (769 individuals) matched to the OTC dataset.
} 
peak enrollment in the fall and spring semesters. We follow the approach employed by Jepsen et al. (2014) in which we assign the spring semester a start date of the first quarter and end date of the second quarter; the summer term is assigned a start date of the second quarter and an end date of the third quarter; and the fall semester is assigned a start date of the third quarter and an end date of the fourth quarter. From this dataset, we can construct a binary measure of enrollment as well as a discrete measure of number of classes taken.

The second dataset includes information on both firms and private sector, state, and local public employees subject to Unemployment Insurance (UI) contributions in Ohio between 1999Q3 and 2013Q1. Thus, an observation exists for every quarter an individual has positive earnings in the state of Ohio during this time period. Importantly, the earnings records include individual identifiers that link to the education data. Thus, for our purposes, we can identify the quarter of a displaced worker's separation as well as the quarter of entry at an Ohio public college or university.

The third dataset includes firm-level variables such as employer identifier, three-digit North American Industry Classification Systems (NAICS) codes, and county of the employer. ${ }^{4}$ The identifiers, all derived from the Quarterly Census of Employment and Wages (QCEW), allow for construction of a firm-size variable by summing across the records associated with a given employer in each quarter.

The Ohio administrative data is particularly advantageous for the purposes of studying displaced workers' earnings patterns and education decisions. Ohio is the seventh largest U.S. state by population and lies at the heart of America's manufacturing region that has experienced several decades of deindustrialization. Between 2005 and 2016, three of top ten "trade-displaced" ZIP codes as calculated from Department of Labor estimates were located in Ohio (Hyman, 2018). The longitudinal nature of the data enables the tracking of worker tenure and enrollment patterns, facilitating the study of questions which could not be feasibly addressed in previous displaced worker studies which relied on information at a highly aggregated geographic level, such as Census division (Betts and McFarland, 1995) or commuting zone (Foote and Grosz, 2019).

\footnotetext{
${ }^{4}$ Note that the employer county data reflects the location of the enterprise. For multi-unit employers, the location of work may not be accurate for a given employee.
} 
The Ohio data nevertheless have some limitations, typical of state administrative UI and education databases. First, we are unable to distinguish between individuals who leave Ohio, exit the labor force, or begin working for non UI-covered employers in the state. Second, we lack demographic information for workers who did not attend Ohio public institutions during the selected timeframe. Third, the education data does not include enrollment records at any private institutions or at public institutions outside of the state of Ohio. Although displaced workers may seek to retrain at private institutions, Xia (2016) shows that two-year for-profit schools respond more strongly to incentives from governmental financial aid availability than local demand for certain skills, the latter of which would be more relevant to our research question. Nevertheless, we use information on location of for-profit colleges to shed light on the role such institutions play for displaced workers.

We use the Ohio administrative records to construct a sample of displaced workers and a comparison group for our analysis of postsecondary enrollment patterns. We describe the construction of such samples below.

\subsection{Displaced Sample}

Displaced workers are typically defined as individuals with stable work histories who involuntarily separate from a firm because of a mass layoff and are unlikely to be recalled to their prior job features which distinguish them from routine job changers or other unemployed individuals (Kletzer, 1998). Because we use administrative data, we cannot explicitly identify the reason for a worker's separation (quit, discharge for cause, etc.). Consistent with the displaced worker literature, we use separations during a mass layoff to identify workers who separate because of economic distress at their firm. Despite concerns that this approach misclassifies voluntary movers as displaced workers, Flaaen et al. (2019) shows that mass layoffs identified in administrative data serve as a reliable proxy for involuntary displacement. ${ }^{5}$

\footnotetext{
${ }^{5}$ Specifically, Flaaen et al. (2019) merges the Longitudinal Employer Household Dynamics (LEHD), an administrative dataset, with the Survey of Income and Program Participation (SIPP), which contains worker-provided reasons for separations. The authors find that earning loss estimates using only survey responses are very close to
} 
We define a mass layoff as a 30\% or more quarter-to-quarter reduction in firm's level of employment, a convention aligned with Davis and Von Wachter (2011). A firm shutdown is counted as a mass layoff. Because some firms exhibit many mass layoffs, we rank a firm's four largest mass layoffs by percentage change during the observed period (2002-2009) and assess only these four events to avoid over-counting. Furthermore, because small employers are mathematically more likely to meet this $30 \%$ benchmark without a substantial change in absolute employment, we adhere to Jacobson et al.'s (1993) practice of excluding firms with fewer than 50 employees from the sample of mass layoff firms.

Upon identifying dates of mass layoffs, we define a displaced worker as someone satisfying the following conditions: the individual (1) worked at a firm experiencing a firm shutdown or mass layoff in 2002q1 through 2009q4 within one year prior to the layoff date; (2) is not employed at the firm the quarter after the mass layoff; (3) worked at the firm continuously for at least three years prior to displacement; (4) holds only one job at the time of job separation; (5) earns the equivalent of at least minimum wage corresponding to 30 hours per week. ${ }^{6}$ This definition aligns with Davis and Von Wachter (2011). Choosing a less-stringent tenure requirement (three years rather than six) allows use to study a greater number of displaced cohorts. ${ }^{7}$

We choose not to impose certain sample restrictions common in studies which examine the effect of job loss on future earnings if the conditioning behavior is correlated with or influenced by the decision to re-enroll. For example, we do not condition that workers in our sample remain attached to the labor force in the post-layoff period. While such a condition may be sensible for studying the wage scarring effects of unemployment, we are interested in the educational rather than employment outcomes of displaced workers. Some workers, particularly those who are not burdened by credit constraints, may opt to devote several years to schooling without balancing those using only administrative data.

${ }^{6}$ Quarterly earnings corresponding to the minimum wage (in 2014 inflation adjusted dollars) is $\$ 2,163$ in the quarter before displacement. This corresponds to earning $\$ 5.15$ hour, Ohio's minimum wage from 2002-2006, for 30 hours per week for one full quarter.

${ }^{7}$ Lachowska et al. (2019) show that job displacement depresses long-run hours worked for employees with higher tenure (6 years) compared to lower tenure (3-4 years). To the extent that this suggests our sample is less attached to the labor force and more likely to return to school after layoff, our study's baseline estimates could be even lower if we restricted to six years of pre-displacement tenure. 
a full-time work schedule. This sample selection criterion renders our paper's conclusions about educational choices relevant for all displaced workers, not just those attached to the labor force.

Likewise, we also do not impose that displaced workers claim unemployment insurance benefits upon job loss because, once again, such a condition influences one's decision to enroll in postsecondary education (Barr and Turner, 2018). Further, such a restriction would omit a substantial share of the population of interest from the sample. Auray et al. (2019) find that from 1989-2012, $23 \%$ of Americans eligible for UI benefits did not claim them. Moreover, the insured unemployment rate - defined as the number of unemployed individuals receiving UI benefits as a percentage of the labor force - during the Great Recession never eclipsed 5.0\% even as the overall unemployment rate peaked at $10.0 \%$.

\subsection{Comparison Sample}

We then create a sample of individuals who are not displaced throughout the whole panel. On these comparison and displaced samples, we estimate our multi-period individual fixed effects model, described in section 4, to compare enrollment outcomes before and after displacement. Traditionally, the displaced worker literature has used a "never displaced" control group of workers who remain continuously employed in order to isolate the share of future potential earnings that is destroyed when an individual involuntarily separates from a particular job. However, in our case, the outcome of interest is the likelihood of post-secondary enrollment instead of earnings. Thus, there is no need to compare a displaced worker to one who remained continuously at the same job.

We define a non-displaced worker as someone satisfying the following conditions: the individual (1) is continuously employed (but not necessarily at the same employer) throughout the whole panel (1999-2012); (2) had at least 3 years of tenure at any firm; (3) earns at least minimum wage corresponding to 30 hours per week. These latter two restrictions ensure our comparison group is similar to our treatment group, which has these same requirements. By limiting our comparison group to those who are continuously employed, we would if anything overstate the effects on education college enrollments. This comparison group has a higher opportunity cost 
of college enrollment, and would presumably be less sensitive to other factors driving education enrollments.

\section{Empirical Approach}

To infer the causal effect of displacement on various educational outcomes, we apply the standard multi-period individual fixed effect with comparison group model that has frequently been used to measure the effect of job loss on earnings (Jacobson et al., 1993; Davis and Von Wachter, 2011; Lachowska et al., 2019; Moore and Scott-Clayton, 2019). Our preferred measure of enrollment is cumul_enroll $_{i t}$, an indicator which assumes zero for each worker $i$ until the first time she enrolls in a public college or university. cumul_enroll $i t$ equals one during the period of first enrollment, and remains one for the rest of the panel regardless of worker $i$ 's enrollment status.

On the sample of displaced workers and non-displaced comparisons, we estimate

$$
\text { cumul_enroll }_{i t}=\alpha_{i}+\gamma_{t}+\lambda_{i} \cdot t+W_{i t} \beta+\sum_{k=-2}^{12} \delta_{k} \cdot D_{i t k}+\varepsilon_{i t}
$$

where the variable of interest $D_{i t k}$ is an indicator that equals one if worker $i$ is observed in quarter $k$ relative to displacement in time period $t$, and equals zero otherwise. The final quarter of a displaced worker's observed tenure with the layoff firm is reflected when $k$ assumes the value zero. We allow the index $k$ to assume negative values as low as -2 , because a worker may enroll in college in anticipation of a layoff that has not yet occurred. $k$ assumes a maximum value of 12 , thus restricting measurement of the effect of displacement to three full post-layoff years. The "omitted category" for the treated sample includes earnings in quarters $-8 \leq k \leq-3$. Because the within-worker residuals cannot be assumed to be independent across time, we cluster at the worker level.

In equation (1), $\alpha_{i}$ are worker fixed effects which absorb an individual's constant propensity to enroll in public college over the length of the panel. Year-quarter time fixed effects, $\gamma_{t}$, capture any non-linear time effects of enrollment common across all workers (such as during the beginning of the Great Recession). We include worker-specific linear time trends, denoted by $\lambda_{i}$, which absorb any 
linear differential trend across workers. These worker-specific time trends account for the fact that the change in one's likelihood of enrolling college over time is much greater for some workers than others. For example, workers in different industries or occupations may have systematically different enrollment trends over time, even in the absence of displacement. These worker-specific trends will thus also control for differential trends by industry or occupation. Similarly, older workers are typically less likely to enroll in postsecondary school because they have fewer years left in the labor market to reap the returns of such education. Because we suspect the probability of enrollment is correlated with worker age ${ }^{8}$, we consider one of the main values of worker-specific linear time trends in this case is to account for potentially differential time trends by age. Lastly, recognizing that workers with lower earnings are more likely to be displaced and, holding other factors constant, should be differentially more likely to enroll in college to increase future earnings, we further control for pre-layoff earnings interacted with time dummies. Specifically, $W_{i t}$ is a vector of year-quarter indicators interacted with the log of pre-displacement earnings (average of the 5-8 quarters before separation for the treatment group, average of 2003 earnings for comparison group), capturing any non-linear differential time-trends by pre-displacement earnings.

In order to identify $\hat{\delta}_{k}$ coefficients from equation (1) as a causal effect of displacement, we need to assume that displacement was orthogonal to unobserved, non-linear trends in employment or human capital. For example, if a worker receives a positive or negative shock that affects both post-secondary enrollment decisions and displacement, our approach will attribute any change in enrollment patterns to displacement rather than to this other shock. Another concern would be if employers specifically target workers for displacement that they know are planning to return to school. While it is not possible to fully rule out all alternative explanations, we do test the sensitivity of our results to alternative specification choices. We include several robustness checks in Appendix A, including models without individual-specific trends and examining effects for shutdowns versus mass layoffs separately. In addition, we also run our main specification separately for subgroups by industry, geography, and earnings percentile.

\footnotetext{
${ }^{8}$ Like many state administrative employment datasets, our sample lacks information on employees' ages.
} 
We use several measures of enrollment throughout our analysis. Our preferred dependent variable is the cumulative indicator of any enrollment, cumul_enroll $i$, as defined above. We also examine an alternative point-in-time measure of enrollment, enroll ${ }_{i t}$, which indicates enrollment in an institution of higher education for worker $i$ in year-quarter $t .{ }^{9}$ Additionally, we use transcript information to construct a cumulative measure of college credits attained, cumul_credit $t_{i t}$, as a dependent variable in robustness checks.

\section{Results}

\subsection{Descriptive statistics on displaced workers and college enrollment}

Table 1 describes basic characteristics of the displaced and non-displaced samples. Displaced workers are slightly more likely to have ever enrolled in a 2-year institution but less likely to have ever enrolled in a 4-year institution compared to non-displaced workers. Pre-displacement earnings are slightly lower for displaced workers than comparison workers in 2005Q1. There are also notable differences in their industry composition: displaced workers are substantially more likely than comparison workers to have been employed in construction, manufacturing, transportation and warehousing, and administrative, support, and waste management. Nearly half of all displaced workers were laid off from three 2-digit NAICS industries: manufacturing, construction, and retail trade.

Table 2 provides further details about displaced workers who enrolled in postsecondary education at some point between 2000 and 2011. The first column describes those who ever enrolled, the second describes those who enrolled after displacement, and the third describes displaced workers who enrolled for the first time as undergraduates after displacement. By comparing the sample size in the second column of Table 2 to the total sample of displaced workers from Table 1, we note that just under $10 \%$ of displaced workers exhibit a spell of post-layoff enrollment. The three samples are

\footnotetext{
${ }^{9}$ We consider enrollit a less illuminating measure with respect to the question of how many workers enroll in college as a result of displacement because resulting $\hat{\delta}_{k}$ coefficients only reveal how many displaced workers are induced to enroll at a given point in time. In theory, the set of workers who enroll in year-quarter $k_{0}$ relative to displacement could be the same or an entirely different set of individuals for all values $t$ where $t \neq k_{0}$.
} 
broadly similar in terms of their demographics and academic characteristics, although those who enroll for the first time (in our sample window) after displacement are older at the time of layoff and first enrollment than their peers. Interestingly, while the majority of enrollment for all three groups occurs at two-year institutions, $37 \%$ of displaced workers enrolled in a four-year institution after displacement, and $7 \%$ enrolled in a graduate program.

Displaced workers enroll in a wide range of fields, but health, engineering, and business are the most popular. Among those who enroll after layoff, $29 \%$ of them earn a degree within two years of displacement. Note that only $37 \%$ of workers who enrolled after job loss were unemployed in the quarter after displacement, and $51 \%$ were working more than part-time. Thus, the decision to return to school or continue seeking work is not a mutually exclusive one for displaced workers.

Data limitations prevent us from comparing the demographic information of workers who enroll in college to those who do not enroll. Nevertheless, we find roughly half of the displaced workers who enroll in an institution of higher education are female and $15 \%$ are non-white (Table 2). Among such workers, the median age at displacement and enrollment were 32 and 35, respectively.

Table 3 further describes patterns of educational enrollment and attainment for displaced workers who pursued school after layoff. On average, most displaced workers enroll as part-time students within two years after displacement and remain enrolled for over a year. Among those who earn a degree within four years after displacement (about 30\% of displaced workers), about $40 \%$ earn an associate's degree, and 30\% earn a bachelor's and 12\% attain a master's degree.

We explore enrollment patterns of displaced workers according to the industry of their layoff employers in Table 4. Among our sample who enrolls in college after job loss, workers displaced from industries with lower-earnings - retail trade, transportation and warehousing, arts and entertainment, and food and accommodation services - skew much younger than the rest of the sample (median age 24 at layoff), while displaced manufacturing employees are substantially older (age 38). Nearly two-thirds of workers displaced from education and health services who seek postsecondary training do so at 4-year institutions, while this number is only $25 \%$ for manufacturing (the vast majority attend 2-year schools). Those displaced from education and health are the only group 
which pursue graduate enrollment at any appreciable rate (23\%), while upwards of $95 \%$ of displaced workers from all other sectors attend undergraduate programs.

We also examine fields of study pursued by displaced workers from different industries. Although we lack occupational data, previous research has documented that students exiting from specific occupations such as health and law enforcement enroll in community college programs that require similar skills (Acton, 2020). In our Ohio sample, many former manufacturing employees study engineering upon college enrollment (22\% compared to $16 \%$ of overall displaced workers who enroll after layoff). Unsurprisingly, 39\% of those laid off from education and health services pursue postsecondary training in health-related fields (and another $9 \%$ in education). This group is also disproportionately likely to pursue social and behavioral sciences (14\% compared to $9 \%$ average). Those originating from the aforementioned low-wage industries pursue many different areas of study after job loss, including health (20\%), business (17\%), social and behavioral science (14\%), arts and humanities (12\%), and natural science and mathematics (10\%).

\subsection{Main Results}

Before turning to effects on enrollment, it is useful to establish that the workers in our sample experience the same employment and earnings outcomes of displacement as has been documented by prior research. Figure 1 illustrates the well-documented effects of job displacement on employment and earnings for workers in our Ohio sample. ${ }^{10}$ Four years after job loss, $15 \%$ of workers are not employed. They earn roughly 25\% less than they would if they had not been displaced, a number consistent with the literature since Jacobson et al. (1993). Using the same administrative data and a very similar displaced sample, Moore and Scott-Clayton (2019) estimate about a 10-12 percentage point negative effect of displacement in a mass layoff on the likelihood of employment several years later. It is possible some of these unemployed individuals are enrolled in an institution of higher education, many are likely searching for a job, retired, or accepting public benefits such as disability insurance which keep them out of the labor force. Moreover, a number of the displaced workers

\footnotetext{
${ }^{10}$ Coefficients plotted in Figure 1 result from specifications similar to equation (1), with employment status or log earnings as a dependent variable. These specifications do not use worker-specific linear time trends.
} 
who do enroll in school may be working full- or part-time contemporaneously.

Figure 2 plots two different measures of the enrollment rate for the comparison sample and cohort displaced in 2006Q1 and provides plausible evidence that our displaced and comparison samples follow similar enrollment trends prior to displacement. The point-in-time enrollment rate from Figure 2a exhibits a declining trend over time, likely representing age effects (enrollment declines as individuals get older). Figure $2 \mathrm{~b}$ plots a cumulative enrollment rate, which increases over time but at a decreasing rate. The figure suggests that job displacement may have a positive effect on college enrollment. Further, enrollment appears to increase modestly at the time of or just before layoff. We quantify this effect by estimating the impact of displacement in the 2 quarters preceding layoff in specification (1).

Figure 3 plots the estimated coefficients from our main specification (listed in Table 5), which can be interpreted as the cumulative effect of job displacement on public college enrollment. We find that the enrollment response to job displacement is statistically significant but very small: for every 100 displaced workers, only 1 is ever induced to enroll in a public college within three years of layoff. Nearly the entire effect of displacement on enrollment occurs in the first year after layoff. The stability of the $\hat{\delta}_{k}$ coefficients for $k>4$ suggest that virtually no new workers are induced to enroll after the first year.

We subject our main finding, that displacement has a positive but limited effect on public college enrollment, to several robustness checks in Appendix A. First, we apply our preferred specification without worker-specific linear time trends - to the displaced and comparison sample. Figure A.6 estimates a noticeably larger but still limited effect of 2.5 workers per every 100 who enroll as a result of displacement. Additionally, we use two alternative measures of enrollment: a quarter-varying enrollment indicator (as from Figure 2a) and a cumulative measure of college credits attained, constructed from student-level transcript information. Both suggest a small but positive effect of displacement on enrollment (Figures A.7 and A.8).

These results are highly consistent with Frenette et al. (2011) who find that for every 100 displaced workers in Canada, one worker is induced to return to school. Most of the "enrollment 
effect" occurs within the first year after displacement. Even though effects of displacement on enrollment seem small, it's worth noting that the causal effect of displacement on employment is only about 10 percentage points (Moore and Scott-Clayton, 2019).

\subsection{Heterogeneity in Enrollment Effects}

\subsubsection{Industry of Layoff}

We first explore whether propensity to enroll in college as a result of displacement varies considerably by industry. Theory might suggest that workers in industries such as manufacturing facing permanent disruptions (Baily and Bosworth, 2014; Pierce and Schott, 2016) might be more likely to return to school to retrain rather than try to find another similar job. On the other hand, older displaced workers have a shorter time horizon to recoup the payoff from additional educational investment and may be overrepresented in industries facing permanent disruptions like manufacturing. ${ }^{11}$

To maintain statistical power, we divide our displaced and non-displaced comparison samples into four broad industrial groups: manufacturing (NAICS 31-33), educational services, health care and social assistance (NAICS 61-62), wholesale trade, retail trade, transportation and warehousing, arts, entertainment, recreation, accommodation and food services (NAICS 42, 44-45, 48-49, 71, 72), and a remaining miscellaneous group. We apply equation (1) separately to each group. Results are presented in Figure 4 and Appendix Table A.3.

Former manufacturing employees clearly drive the bulk of the college enrollment response to displacement. These workers exhibit a strong enrollment response soon after displacement, as 2 in every 100 manufacturing workers had enrolled in college just four quarters after layoff. After four years, more than 2.5 displaced Ohio manufacturers pursued public college as a result. These workers contrast sharply with those laid off from other sectors, who do not appear to be induced to public college enrollment after job loss. While those laid off from retail, wholesale, transportation and warehousing, arts, entertainment, food and accommodation exhibit a modest significant

\footnotetext{
${ }^{11}$ Because of Ohio sample's limitations on demographic information, we examine demographics by industry of layoff for those in the Displaced Workers Supplement (DWS) of the Current Population Survey in Appendix C. We document that those laid off from manufacturing are, on average, among the oldest displaced workers (Table C.2).
} 
positive effect in the first post-layoff year, after three years their likelihood of enrollment is not distinguishable from zero. Displaced workers in education, health, and the "other" category never enroll in college at a significant rate.

Because employees displaced from manufacturing account for the vast majority of those who consequently enroll, we focus our subsequent heterogeneity analysis on these workers. Restricting to a more homogenous set of workers in the same industry will allow to better assess how enrollment responses to displacement vary along other dimensions. As Table 4 describes, these laid off individuals are much more likely to enroll in two-year institutions than other displaced workers. Their most common fields of study are health, engineering, and business. At a national level, displaced manufacturing workers are older (average age at layoff is 44 years) and more likely to be male (62\%). Over half have only a high school diploma or less (Table C.2).

\subsubsection{Within-Firm Earnings}

It is well-documented that earnings increase with firm-tenure (and therefore age) (Brown, 1989; Topel, 1991). While we cannot observe age for all workers directly, displaced workers with lower within-firm earnings may be younger and have more years remaining in their careers. These lowerpaid, often younger workers may find schooling a more attractive pursuit after losing their job than their higher-paid counterparts. Even holding age and other factors constant, one might expect workers with lower incomes to be differentially likely to pursue postsecondary education to increase their human capital and future earnings. This may be especially true in manufacturing, as the highest-paid workers are often engineers or production managers, whose positions require a bachelor's degree and whose skills may be in higher demand at other firms. Those who worked as former assemblers and machinists, positions that are less well-remunerated and don't require a college degree, may have fewer attractive destinations in the labor market. Therefore, we investigate whether the enrollment effect varies by a worker's position within the earnings distribution at her layoff firm.

We divide displaced and comparison manufacturing workers by tercile of earnings within the 
firm and apply equation (1). ${ }^{12}$ Despite splitting the sample by within-firm earnings, we still control for a worker's pre-layoff earnings interacted with time. As Figure 5 illustrates, the percentile of a worker's within-firm earnings strongly predicts college enrollment after layoff. Four quarters after displacement from a manufacturing firm, 4 workers per every 100 from the bottom tercile enrolled in college as a result, compared to just 2 and 1 from the middle and top terciles, respectively. Three years after layoff, the lowest-paid workers are still more than three-times as likely to have enrolled in college than those laid off from the top of the earnings distribution. The finding that lower-earning workers are more likely to enroll in college after displacement is robust to whether workers are divided into two or four groups (Appendix Figure A.1).

\subsubsection{Geographic Access to College}

We next investigate how job loss may have differential effects on enrollment patterns of manufacturing workers with varying proximity to public and for-profit colleges. We assign each displaced and non-displaced comparison worker a local labor market based on the county of her employer according to the Commuting Zone (CZ) scheme developed by Tolbert and Sizer (1996). CZs are clusters of counties that are characterized by commuting ties which are strong within-region and weak across regions. ${ }^{13}$ We then classify each of Ohio's seventeen multi-county $\mathrm{CZs}^{14}$ as either highor low-access in terms of higher education based on the number of institutions in the local labor market. We first designate high- and low-access CZs for public colleges, and then within this stratification we classify CZs by relative availability of for-profit institutions using data on location of for-profits from the Urban Institute's Education Data Portal in order to examine whether for-profit access may depress public enrollment. ${ }^{15}$

\footnotetext{
${ }^{12} \mathrm{~A}$ displaced worker is assigned an earnings tercile based on her earnings in the last full quarter before layoff. Terciles for a comparison worker are assigned based on earnings in 2005Q1.

${ }^{13}$ Because our analysis is conducted at the individual worker-level, we do not implement the clustering robustness check advised by Foote et al. (2017) for empirical labor economics papers which use CZs themselves as the unit of observation.

${ }^{14}$ Two CZs - Huntington, WV and Parkersburg, WV - include only one Ohio county as they are mostly part of West Virginia, so we drop the small number of workers employed in these counties for geographic analysis.

${ }^{15}$ The Urban Institute's data combines information from Integrated Postsecondary Education Data System (IPEDS), the Department of Education's College Scorecard, and the National Historical Geographic Information System (NHGIS)
} 
Because our data is limited to enrollment records at public universities, we cannot directly observe those who retrain at private institutions, including for-profit colleges. In 2009, for-profits accounted for $9 \%$ of nationwide enrollment in degree-granting schools. Deming et al. (2012) find that relative to other institutions, for-profits educate a larger fraction of minority, disadvantaged, and older students and more often grant degrees for short programs at the certificate and AA levels, suggesting they may be more prominent school avenues for displaced workers. Thus, displaced workers may seek retraining at easily accessible for-profits rather than public colleges. When Foote and Grosz (2019) estimate the enrollment response to mass layoff events, they do not find any statistically significant enrollment response at for-profit institutions (in contrast to their findings on public enrollment). However, their point estimate is still more than $50 \%$ as big as their estimate for public enrollment (1.5 for-profit enrollees per 100 displaced workers, versus 2.8 at public colleges), suggesting that for-profits may attract displaced workers at higher rates than they attract other types of students.

First, focusing on proximity to public institutions, we classify six CZs - Cincinnati, Cleveland, Columbus, Dayton, Portsmouth, and Toledo - as 'high-access' given they host at least 7 public colleges or universities. These CZs are home to employers which displace roughly $70 \%$ of the overall sample. Figure 6 presents estimates from specification (1) when splitting the manufacturing sample by high- and low-public college access CZ. In the first post-layoff year, roughly two workers out of every 100 enroll in college regardless of their geographic proximity to public colleges. After three years, these numbers diverge slightly, as roughly 2.5 (3.5) workers of every 100 displaced in a CZ with high (low) proximity to public schools are induced to enroll. The medium-run cumulative effect of displacement on enrollment follows a similar trajectory for both sets of workers: a strong push into enrollment in the first few quarters followed by two years of a gradually increasing effect. Further robustness checks at the county-level (rather than CZ-level) bolster the finding that geographic proximity to public institutions does not strongly predict enrollment propensity (Appendix Figure A.5).

Next, we further classify each high- or low-public college access CZ by its relative geographic 
concentration of for-profits using county-level data from the Urban Institute. ${ }^{16}$ Figure 7 presents the results of equation (1) for these four distinct samples of workers, describing the effect of displacement on public college enrollment by geographic proximity to both for-profits and public institutions. Interestingly, workers are less likely to enroll in public colleges if displaced in local markets with higher concentration of for-profits. This pattern is consistent with other evidence for the substitutability of for-profits and community colleges for displaced workers seeking to retrain. The effect of displacement on public enrollment does not strongly correlate with the number of public options available. $^{17}$

Specifically, workers displaced in local education markets with few for-profit institutions were the most likely to enroll in public college as a result. One year after displacement in these areas, roughly four in 100 displaced workers responded by enrolling. On the other hand, workers in markets with many for-profit institutions enrolled in public colleges at much lower rates in response to job loss. In the first post-displacement year, less than two such displaced manufacturing workers per every 100 enrolled in college. This result depends little on whether workers had many nearby public college options, although enrollment for "high-public, high-for-profit" workers was slightly higher than for "low-public, high-for-profit" counterparts in the first post-layoff year.

In Appendix A.2, we test other dimensions of heterogeneity which could have predictive power for displaced workers' enrollment patterns, such as calendar-quarter of layoff, firm size, and firm shutdown status. In each instance, roughly two of every 100 displaced manufacturing workers from various subgroups were induced to enroll in college.

\footnotetext{
${ }^{16}$ This classification designates Dayton, Portsmouth, and Toledo as high-public and low-for-profit local education markets and Canton, Lorain, and Youngstown as low-public and high-for-profit markets. The remaining CZs are either high- or low-access for both types of schools. For a full list of CZs, their classifications, and number of institutions, see Table B.1.

${ }^{17}$ This may be because CZs with many public options also may have more alternative job options for displaced workers, or it may indicate that one public option is as useful as multiple public options when it comes to enrollment decisions.
} 


\section{Discussion and Conclusion}

Despite the documented benefits of postsecondary education after a mass layoff (Jacobson et al., 2005a,b), job displacement is found to be associated with only a modest increase in college enrollment. For every 100 displaced workers, only about 1 is ever induced to enroll in a public college within four years of layoff. Workers are most likely to pursue higher education in the first post-layoff year, with the median enrollment spell lasting five semesters. Very few workers are induced into enrollment beyond the first few quarters post-layoff. The sizable difference between these small causal estimates and the post-layoff probability of displaced workers' college enrollment observed in the data $(9 \%)$ suggests that the majority of displaced individuals who enroll in college post-displacement would have likely done so even the absence of a job loss.

Our causal estimates are comparable to those from the limited empirical work on postsecondary enrollment patterns of displaced workers in other settings. Our baseline estimate that 1 out of every 100 displaced workers enrolls in college as a result of displacement is similar to Frenette et al. (2011), who estimate an effect of between 0.6 to 1.3 workers for every 100 displaced workers in Canada. ${ }^{18}$ Our estimates are also in line with those from Foote and Grosz (2019), who estimate that for every 100 workers involved in mass layoff, 3 enrolled in a two-year college after three years. ${ }^{19}$

Our quantitatively-small estimate of displacement's effect on college enrollment, if anything, may overstate the true response we seek to measure. To obtain a causal estimate, we followed the displacement-earnings literature's long-standing approach by comparing the outcomes of our displaced sample's to those of a stably-employed control (Jacobson et al., 1993; Davis and Von Wachter, 2011; Lachowska et al., 2019). Our dynamic difference-in-difference model, which controls for individual-specific trends over time, assumes that displaced and comparison workers do not differentially deviate from these trends over time except for the effects of displacement. However, to

\footnotetext{
${ }^{18}$ Frenette et al.'s (2011) estimates vary based on definition of displacement. Their definition most similar to ours (using mass layoffs to proxy for job displacement) yields estimates of $0.6 \%$ for males and $1.3 \%$ for females.

${ }^{19}$ Although Jacobson et al. (2005a) do not estimate a reduced-form effect of job loss on enrollment, the authors document that roughly $15 \%$ of displaced workers in 1990s Washington state later enroll in a 2-year community college. Although this is larger than our sample's post-layoff enrollment rate of $9 \%$, the magnitudes of these descriptive patterns are reasonably aligned.
} 
the extent this assumption is violated (for example if some third factor contributes to both higher displacement and higher enrollment, or if employers displace workers they expect to enroll), this violation is likely to overestimate the enrollment response because workers in the continuouslyattached comparison group exhibit such a high degree of employment stability that there could be less of motive for this group to seek postsecondary schooling at any point during their tenure.

Our findings of the heterogeneous effects of job loss on enrollment support our causal interpretation. For example, our conclusion that displaced workers in local labor markets with more for-profit institutions are less likely to enroll in public colleges than counterparts in low-for-profit markets (independent of public-college concentration) accords with prior research indicating that public and for-profit schools are substitutes (Laband and Lentz, 2004; Cellini, 2009; Cellini et al., 2020).

A possible explanation for the small magnitude of effects could be that those who do experience persistent employment and earnings declines following a layoff may also face greater financial constraints (Ganong and Noel, 2019), depressing college enrollment. Student aid policies and labor market policies - including UI - can play a role in determining how and whether displaced workers engage in postsecondary education (Barr and Turner, 2015). Information failures could also play a role if displaced workers are not aware of the aid available to them. During the Great Recession, the State of Ohio sent out letters to UI recipients proactively informing them of their eligibility for federal Pell Grants. Barr and Turner (2018) studied this policy, exploiting the idiosyncratic timing of when the letters were sent in different areas, and concluded that the letters significantly increased the likelihood of college enrollment. ${ }^{20}$

Finally, while our estimated effect of displacement on college enrollment appears objectively small, it is worth placing the magnitude of this finding in context of post-displacement employment patterns, which indicate that most displaced workers quickly return to other jobs. For example, (Moore and Scott-Clayton, 2019) estimate a 10-12 percentage point negative effect of layoff on likelihood of employment several years later using the same administrative data and a very similar

\footnotetext{
${ }^{20}$ Note, however, that according to Unemployment Insurance summary data from the US Department of Labor from 2019Q4, only 3 in 10 unemployed workers received UI benefits, so even these letters would not reach all the displaced workers considered in our sample. Further, Ohio did not send letters to UI recipients until December 2009, after the period of displacements that we examine in this analysis.
} 
displaced sample. Lachowska et al. (2019) estimate an even smaller long-term impact on employment (a 3-4 percentage point decline) on displaced workers in Washington State during the Great Recession. It would be surprising for the share seeking retraining to be larger than the share remaining jobless in the years following separation. Still, interpreted along with other evidence, our results suggest that more work may be needed to ensure that college enrollment is an accessible option for displaced workers seeking to retrain. 


\section{References}

Acton, R. K. (2020): "Community College Program Choices in the Wake of Local Job Losses," .

Albertini, J. And X. FAirise (2018): "Layoffs, recalls and experience rating," .

Auray, S., D. L. Fuller, And D. Lkhagvasuren (2019): "Unemployment insurance take-up rates in an equilibrium search model," European Economic Review, 112, 1-31.

Autor, D., D. Dorn, And G. H. Hanson (2013): "The China syndrome: Local labor market effects of import competition in the United States," American Economic Review, 103, 2121-68.

Autor, D. H. And M. G. DugGan (2003): "The rise in the disability rolls and the decline in unemployment," The Quarterly Journal of Economics, 118, 157-206.

Baily, M. N. AND B. P. Bosworth (2014): "US manufacturing: Understanding its past and its potential future," Journal of Economic Perspectives, 28, 3-26.

Barr, A. And S. Turner (2015): "Out of work and into school: Labor market policies and college enrollment during the Great Recession," Journal of Public Economics, 124, 63-73.

- (2018): "A Letter and Encouragement: Does Information Increase Postsecondary Enrollment of UI Recipients?" American Economic Journal: Economic Policy, 10, 42-68.

Barrow, L. AND J. DAvis (2012): "The upside of down: Postsecondary enrollment in the great recession," Economic Perspectives, 36.

Berger, M. C. And T. Kostal (2002): "Financial resources, regulation, and enrollment in US public higher education," Economics of Education Review, 21, 101-110.

Betts, J. R. and L. L. McFarland (1995): "Safe port in a storm: The impact of labor market conditions on community college enrollments," Journal of Human Resources, 741-765.

Brand, J. E., B. R. Levy, And W. T. Gallo (2008): "Effects of layoffs and plant closings on subsequent depression among older workers," Research on Aging, 30, 701-721.

Brown, J. N. (1989): "Why do wages increase with tenure? On-the-job training and life-cycle wage growth observed within firms," The American Economic Review, 971-991.

CARD, D. (1993): "Using geographic variation in college proximity to estimate the return to schooling," Tech. rep., National Bureau of Economic Research.

Card, D. And T. Lemieux (2001): "Dropout and enrollment trends in the postwar period: What went wrong in the 1970s?" in Risky Behavior Among Youths: An Economic Analysis, University of Chicago Press, 439-482.

Card, D. And P. Oreopoulos (2019): "Introduction: Labor Markets and Public Policies in the United States and Canada," Journal of Labor Economics, 37, S243-S252.

Card, D. And W. C. Riddell (1993): "A comparative analysis of unemployment in Canada and the United States," in Small differences that matter: Labor markets and income maintenance in Canada and the United States, University of Chicago Press, 149-190.

Cellini, S. R. (2009): "Crowded colleges and college crowd-out: The impact of public subsidies on the two-year college market," American Economic Journal: Economic Policy, 1, 1-30.

Cellini, S. R., R. Darolia, And L. J. Turner (2020): "Where Do Students Go When For-Profit Colleges Lose Federal Aid?" American Economic Journal: Economic Policy, 12, 46-83.

Charles, K. K. And M. Stephens, Jr (2004): "Job displacement, disability, and divorce," Journal of Labor Economics, 22, 489-522. 
Davis, S. J. And T. Von Wachter (2011): "Recessions and the Costs of Job Loss," Brookings Papers on Economic Activity, 42, 1-72.

Deming, D. J., C. Goldin, And L. F. Katz (2012): "The for-profit postsecondary school sector: Nimble critters or agile predators?" Journal of Economic Perspectives, 26, 139-64.

FARBER, H. S. (2015): "Job loss in the great recession and its aftermath: US evidence from the Displaced Workers Survey," Tech. rep., National Bureau of Economic Research.

FlaAen, A., M. D. Shapiro, And I. Sorkin (2019): "Reconsidering the Consequences of Worker Displacements: Firm versus Worker Perspective," American Economic Journal: Macroeconomics, 11, 193-227.

Foote, A. And M. Grosz (2019): "The effect of local labor market downturns on postsecondary enrollment and program choice," Education Finance and Policy, 1-50.

Foote, A., M. Grosz, And A. Stevens (2019): "Locate Your Nearest Exit: Mass Layoffs and Local Labor Market Response," ILR Review, 72, 101-126.

Foote, A., M. Kutzbach, And L. Vilhuber (2017): "Recalculating-How uncertainty in local labor market definitions affects empirical findings," .

Frenette, M., R. Upward, And P. W. Wright (2011): "The long-term earnings impact of postsecondary education following job loss," Statistics Canada Analytical Branch Studies Working Paper.

Fujita, S. And G. Moscarini (2017): "Recall and unemployment," American Economic Review, 107, 3875-3916.

Ganong, P. And P. Noel (2019): "Consumer spending during unemployment: Positive and normative implications," American Economic Review, 109, 2383-2424.

Handwerker, E. W. AND L. G. MAson (2012): "Which layoffs-and which laid-off workers-are in the mass layoff statistics," Monthly Lab. Rev., 135, 17.

Hillman, N. W. And E. L. Orians (2013): "Community colleges and labor market conditions: How does enrollment demand change relative to local unemployment rates?" Research in Higher Education, $54,765-780$.

Hipple, S. (1999): "Worker displacement in the mid-1990s," Monthly Lab. Rev., 122, 15.

Hyman, B. (2018): "Can Displaced Labor Be Retrained? Evidence from Quasi-Random Assignment to Trade Adjustment Assistance," .

Jacobson, L. S., R. J. LaLonde, And D. G. Sullivan (1993): "Earnings losses of displaced workers," The American Economic Review, 685-709.

- (2005a): "Estimating the returns to community college schooling for displaced workers," Journal of Econometrics, 125, 271-304.

- (2005b): "The impact of community college retraining on older displaced workers: Should we teach old dogs new tricks?" ILR Review, 58, 398-415.

Jepsen, C., K. Troske, And P. Coomes (2014): "The labor-market returns to community college degrees, diplomas, and certificates," Journal of Labor Economics, 32, 95-121.

Johnson, L. (1996): "Common Ground: Exemplary Community College and Corporate Partnerships." . Jones, S. R. And W. C. Riddell (2019): "Unemployment, Marginal Attachment, and Labor Force Participation in Canada and the United States," Journal of Labor Economics, 37, S399-S441.

Kletzer, L. G. (1998): "Job Displacement," Journal of Economic Perspectives, 12, 115-136. 
Laband, D. N. And B. F. Lentz (2004): "Do costs differ between for-profit and not-for-profit producers of higher education?" Research in Higher Education, 45, 429-441.

Lachowska, M., A. Mas, And S. A. Woodbury (2019): "Sources of Displaced Workers' Long-Term Earnings Losses," Tech. rep., National Bureau of Economic Research.

LaLonde, R. And D. Sullivan (2010): "Retraining Displaced Workers. Policy Brief." Hamilton Project.

Lendel, I., M. Piazza, And M. Ellerbock (2019): "Lordstown GM Plant Closure Economic Impact Study," .

Leung, P. And Z. Pei (2020): "Further Education During Unemployment," .

Maher, K. (2018): "GM's Plan to Drop Chevy Cruze Hits Ohio Town Hard," .

Milligan, K. And T. Schirle (2019): "Push and pull: Disability insurance, regional labor markets, and benefit generosity in Canada and the United States," Journal of Labor Economics, 37, S289-S323.

Moore, B. And J. Scott-Clayton (2019): "The Firm's Role in Displaced Workers' Earnings Losses," Tech. rep., National Bureau of Economic Research.

NEAL, D. (1995): "Industry-specific human capital: Evidence from displaced workers," Journal of Labor Economics, 13, 653-677.

Ost, B., W. PAn, And D. WebBer (2018): "The impact of mass layoffs on the educational investments of working college students," Labour Economics, 51, 1-12.

Pierce, J. R. And P. K. Schott (2016): "The surprisingly swift decline of US manufacturing employment," American Economic Review, 106, 1632-62.

Roueche, J. E. ET AL. (1995): The Company We Keep: Collaboration in the Community College., ERIC - Education Resources Information Center, U.S. Department of Education.

Schmieder, J. F. AND T. Von WAChter (2010): "Does wage persistence matter for employment fluctuations? Evidence from displaced workers," American Economic Journal: Applied Economics, 2, 1-21.

Sullivan, D. And T. Von Wachter (2009): "Job displacement and mortality: An analysis using administrative data," The Quarterly Journal of Economics, 124, 1265-1306.

Tolbert, C. M. And M. Sizer (1996): "US commuting zones and labor market areas: A 1990 update," Tech. rep.

Topel, R. (1991): "Specific capital, mobility, and wages: Wages rise with job seniority," Journal of Political Economy, 99, 145-176.

Von Wachter, T., J. Song, and J. Manchester (2009): "Long-term earnings losses due to mass layoffs during the 1982 recession: An analysis using US administrative data from 1974 to 2004," Unpublished paper, Columbia University.

XiA, X. (2016): "What explains the rise of for-profit universities? Evidence from dental assistant programs," Columbia University Job Market Paper. 


\section{Figures}

Table 1: Descriptive Statistics for Displaced and Comparison Group

\begin{tabular}{lcc}
\hline & Displaced & Comparison \\
\hline Industry of Layoff Firm & & \\
Agriculture, Fishing, Hunting & 0.008 & 0.001 \\
Mining, Quarrying, Oil and Gas Extract & 0.006 & 0.003 \\
Utilities & 0.001 & 0.010 \\
Construction & 0.100 & 0.021 \\
Manufacturing & 0.285 & 0.240 \\
Wholesale Trade & 0.029 & 0.057 \\
Retail Trade & 0.107 & 0.090 \\
Transportation and Warehousing & 0.078 & 0.031 \\
Information & 0.019 & 0.027 \\
Finance and Insurance & 0.083 & 0.074 \\
Real Estate and Rental Leasing & 0.008 & 0.011 \\
Professional, Scientific, and Technical & 0.038 & 0.042 \\
Management of Companies and Enterprises & 0.006 & 0.008 \\
Administrative, Support, Waste Management & 0.058 & 0.028 \\
Educational Services & 0.021 & 0.111 \\
Health Care and Social Assistance & 0.052 & 0.142 \\
Arts, Entertainment, Recreation & 0.025 & 0.006 \\
Accommodation and Food Services & 0.042 & 0.027 \\
Other Services & 0.019 & 0.015 \\
Public Administration & 0.012 & 0.053 \\
Yearly Pre-Layoff Earnings & & \\
1-4 Quarters Before (\$) & 49,888 & 54,153 \\
& $(38,976)$ & $(37,491)$ \\
Higher Education & & \\
Ever Enrolled in 2-Year Institution & 0.113 & 0.094 \\
Ever Enrolled in 4-Year Institution & 0.062 & 0.086 \\
\hline$N$ & 68,547 & 898,040 \\
\hline \hline
\end{tabular}

Note: Standard errors for earnings are expressed in parentheses. Table lists the share of workers displaced from various industries between 2002q1 and 2009q4. Earnings are in inflation-adjusted to USD $\$ 2012$ using the CPI-U. Industries are listed at 2-digit NAICS level. Because the comparison group is never displaced, industries represent their industry of employment in 2005q1. "Pre-layoff earnings" for the comparison group is four times their 2005q1 earnings. 
Table 2: Summary Statistics: Displaced Workers with Enrollment Records

\begin{tabular}{|c|c|c|c|}
\hline & \multicolumn{3}{|c|}{ Displaced Workers, 2002q1-2009q4 } \\
\hline & $\begin{array}{l}\text { Ever enrolled, } \\
\text { 2000-2011 }\end{array}$ & $\begin{array}{l}\text { Enrolled Post- } \\
\text { Displacement }\end{array}$ & $\begin{array}{c}\text { First Time UG Enroll } \\
\text { Post Displacement }\end{array}$ \\
\hline \multicolumn{4}{|l|}{ Basic Demographics } \\
\hline Female & 0.48 & 0.48 & 0.49 \\
\hline Non-white & 0.14 & 0.14 & 0.15 \\
\hline Age at Displacement (median) & 32 & 32 & 35 \\
\hline Age at First Enrollment (median) & 35 & 35 & 38 \\
\hline \multicolumn{4}{|l|}{ Enrollment } \\
\hline Any Enrollment in 2-yr Institution & 0.72 & 0.76 & 0.77 \\
\hline Any Enrollment in 4-yr Institution & 0.39 & 0.37 & 0.32 \\
\hline Any Undergraduate Enrollment & 0.95 & 0.96 & 0.94 \\
\hline Any Graduate Enrollment & 0.06 & 0.07 & 0.08 \\
\hline \multicolumn{4}{|l|}{ CIP Area at First Enrollment } \\
\hline Arts \& Humanities & 0.14 & 0.11 & 0.12 \\
\hline Business & 0.16 & 0.15 & 0.16 \\
\hline Education & 0.05 & 0.05 & 0.05 \\
\hline Engineering & 0.16 & 0.16 & 0.15 \\
\hline Health & 0.16 & 0.20 & 0.21 \\
\hline Law & 0.01 & 0.01 & 0.01 \\
\hline Natural Science \& Mathematics & 0.08 & 0.09 & 0.08 \\
\hline Services & 0.04 & 0.04 & 0.04 \\
\hline Social \& Behavioral Sciences & 0.09 & 0.09 & 0.07 \\
\hline Trades \& Repair Technicians & 0.03 & 0.03 & 0.04 \\
\hline \multicolumn{4}{|l|}{ Degree Attainment } \\
\hline Earned Degree w/i 2yrs of Displacement & $\mathrm{N} / \mathrm{A}$ & 0.29 & 0.25 \\
\hline \multicolumn{4}{|l|}{ Employment } \\
\hline Unemployed quarter after layoff & 0.36 & 0.37 & 0.40 \\
\hline More than Part-Time Employment & 0.54 & 0.51 & 0.50 \\
\hline$N$ & 10,780 & 6,306 & 4,197 \\
\hline
\end{tabular}

Note: The first column includes workers displaced between 2002q1 and 2009q4 with any record of enrollment at an Ohio public college or university (community college, 4-year undergraduate, or graduate program) between 2000 and 2011. This group includes workers who pursued higher education before and/or after displacement. The second column isolates displaced workers who enroll in a public college or university after displacement, regardless of enrollment status before job loss. The third column includes only workers who enroll in an undergraduate institution for the first time after they are displaced. 
Table 3: Displaced Workers: Educational Attainment

\begin{tabular}{lcc}
\hline \hline & \multicolumn{2}{c}{$\begin{array}{c}\text { Years From Displacement } \\
\text { to Enrollment }\end{array}$} \\
\cline { 2 - 3 } & $0-2$ years & 2 -4 years \\
\hline Enrollment & 0.732 & 0.725 \\
Any Enrollment in a 2-yr Institution & 0.331 & 0.344 \\
Any Enrollment in a 4-yr Institution & 0.943 & 0.943 \\
Any Undergraduate Enrollment & 0.066 & 0.070 \\
Any Graduate Enrollment & 0.429 & 0.392 \\
Any Full-Time (FT) Enrollment & 0.869 & 0.874 \\
Any Part-Time (PT) Enrollment & \\
Attainment & 11.99 & \\
\# Courses Enrolled within 2 or 4 years & 4.656 & 4.96 \\
\# Quarters Enrolled within 2 or 4 years & 1.327 & 1.251 \\
\# Quarters Enrolled FT w/i 2 or 4 years & 3.062 & 3.295 \\
\# Quarters Enrolled PT w/i 2 or 4 years & 0.302 & 0.325 \\
Earned Degree w/i 2 or 4yrs of Displacement & & \\
Among Those Completing Degree After Layoff & & \\
Less than one-year award & 0.060 & 0.053 \\
Associate's degree & 0.432 & 0.415 \\
Bachelor's degree & 0.289 & 0.305 \\
Master's degree & 0.120 & 0.135 \\
First-professional degree & 0.009 & 0.011 \\
Doctoral degree & 0.022 & 0.011 \\
\hline$N$ & 6,031 & 4,297 \\
\hline \hline
\end{tabular}

Note: First column provides enrollment and attainment variable means for displaced workers who enroll in an institution of higher education any time within the first two years after their displacement (including workers who were enrolled prior to displacement). The second column provides means for the same variables for displaced workers who enroll in an institution of higher education anytime between 2 and 4 years after their displacement. Because some workers enroll in the year after displacement and continue schooling for many years, the two groups are not disjoint. However, the 2-4 group is also not a proper subset of the 0-2 group. Attainment variables for courses and quarters enrolled correspond to either "within 2 years" for the first column or "within 4 years" for the second column. 
Table 4: Summary Statistics: Displaced Workers with Enrollment Records by Industry of Layoff

\begin{tabular}{|c|c|c|c|c|}
\hline & \multicolumn{4}{|c|}{ Displaced Workers, Enrolled Post-Layoff } \\
\hline & Manufacturing & Educ/Health & RWTAEFA & Other \\
\hline \multicolumn{5}{|l|}{ Basic Demographics } \\
\hline Age at Displacement (median) & 38 & 33 & 24 & 34 \\
\hline \multicolumn{5}{|l|}{ Enrollment } \\
\hline Any Enrollment in 2-yr Institution & 0.82 & 0.63 & 0.67 & 0.81 \\
\hline Any Enrollment in 4-yr Institution & 0.25 & 0.62 & 0.53 & 0.29 \\
\hline Any Undergraduate Enrollment & 0.98 & 0.86 & 0.98 & 0.96 \\
\hline Any Graduate Enrollment & 0.02 & 0.23 & 0.08 & 0.06 \\
\hline \multicolumn{5}{|l|}{ CIP Area at First Enrollment } \\
\hline Arts \& Humanities & 0.07 & 0.07 & 0.12 & 0.12 \\
\hline Business & 0.17 & 0.06 & 0.17 & 0.15 \\
\hline Education & 0.02 & 0.09 & 0.08 & 0.04 \\
\hline Engineering & 0.22 & $*$ & 0.08 & 0.21 \\
\hline Health & 0.23 & 0.39 & 0.20 & 0.16 \\
\hline Law & 0.02 & $*$ & $*$ & $*$ \\
\hline Natural Science \& Mathematics & 0.10 & 0.11 & 0.10 & 0.07 \\
\hline Services & 0.03 & 0.03 & 0.05 & 0.05 \\
\hline Social \& Behavioral Sciences & 0.06 & 0.14 & 0.14 & 0.07 \\
\hline Trades \& Repair Technicians & 0.03 & $*$ & $*$ & 0.05 \\
\hline \multicolumn{5}{|l|}{ Employment } \\
\hline Unemployed quarter after layoff & 0.52 & 0.45 & 0.33 & 0.40 \\
\hline More than Part-Time Employment & 0.41 & 0.39 & 0.46 & 0.52 \\
\hline$N$ & 1,240 & 575 & 1,446 & 3,045 \\
\hline
\end{tabular}

Note: This table splits the sample of workers who enroll in a public college after displacement (column 2 of Table 2) by broad industrial category of their layoff employer. The sample includes workers displaced between 2002q1 and 2009q4 with any record of enrollment at an Ohio public college or university after layoff and until 2011. Enrollment rates within a column may sum to more than 1 because workers enroll at multiple types of institutions. RWTAEFA includes workers displaced from Retail Trade, Wholesale, Transportation \& Warehousing, Arts \& Entertainment, and Food \& Accommodation Services. Other includes remaining displaced workers laid off from firms outside manufacturing, education and health services, and RWTAEFA. * indicates that the cell value suppressed, as it represents less than 10 individuals. 
Table 5: Cumulative Effect of Displacement on Enrollment, 2002-2009

\begin{tabular}{lc}
\hline Quarter rel. to displacement & \\
\hline-2 & 0.0002 \\
& $(0.0003)$ \\
-1 & $0.0011^{*}$ \\
& $(0.0005)$ \\
0 & $0.0013^{*}$ \\
& $(0.0006)$ \\
1 & $0.0046^{* * *}$ \\
& $(0.0008)$ \\
2 & $0.0071^{* * *}$ \\
& $(0.0009)$ \\
3 & $0.0086^{* * *}$ \\
& $(0.0010)$ \\
4 & $0.0088^{* * *}$ \\
& $(0.0011)$ \\
5 & $0.0089^{* * *}$ \\
& $(0.0012)$ \\
6 & $0.0087^{* * *}$ \\
& $(0.0014)$ \\
7 & $0.0087^{* * *}$ \\
& $(0.0015)$ \\
8 & $0.0090^{* * *}$ \\
& $(0.0016)$ \\
9 & $0.0087^{* * *}$ \\
& $(0.0017)$ \\
10 & $0.0091^{* * *}$ \\
& $(0.0018)$ \\
11 & $0.0088^{* * *}$ \\
& $(0.0019)$ \\
& $0.0087^{* * *}$ \\
& $(0.0021)$ \\
\hline \hline & $44,291,188$ \\
\hline \multirow{2}{*}{ Observations } & $* 2005$ \\
&
\end{tabular}

Results from specification (1). Standard errors in parentheses; ${ }^{*} p<0.05,{ }^{* *} p<0.01,{ }^{* * *} p<0.001$ 
Figure 1: Effect of Displacement on Employment and Earnings

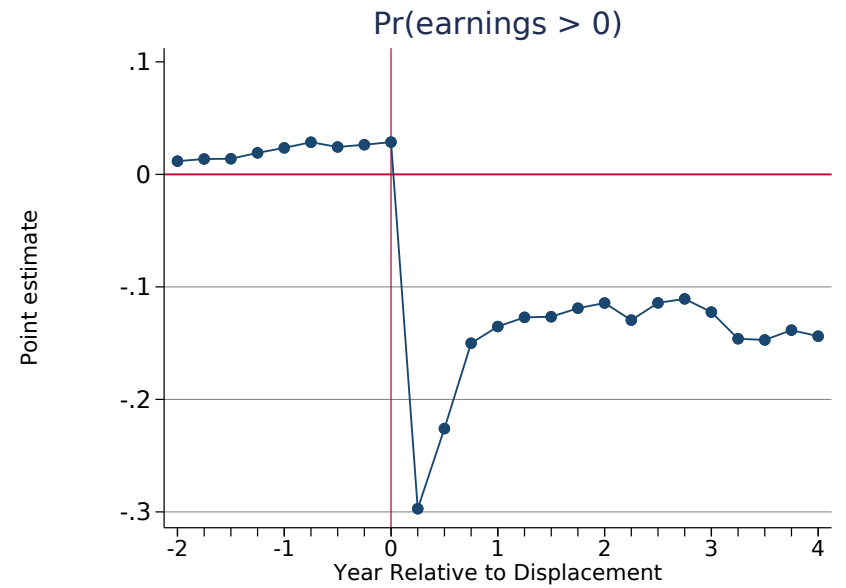

(a) Probability of Employment

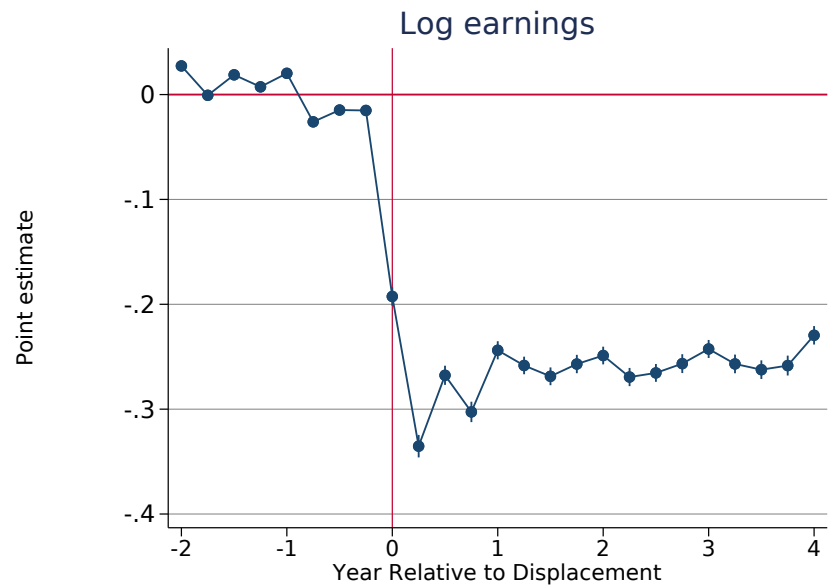

(b) $\log ($ earnings $)$

Note: Figure plots the estimated effect of displacement on a worker's probability of being employed (panel a) and log of earnings (panel b) in a given quarter compared to a stably employed comparison group (always employed at same employer). Whiskers (very small) denote 95-percent confidence intervals based on standard errors clustered by worker. Displaced sample is laid off between 2002q1 and 2008q4 (total sample for the paper is 2002-2009).

Figure 2: Enrollment Rates of Displaced and Non-Displaced Workers

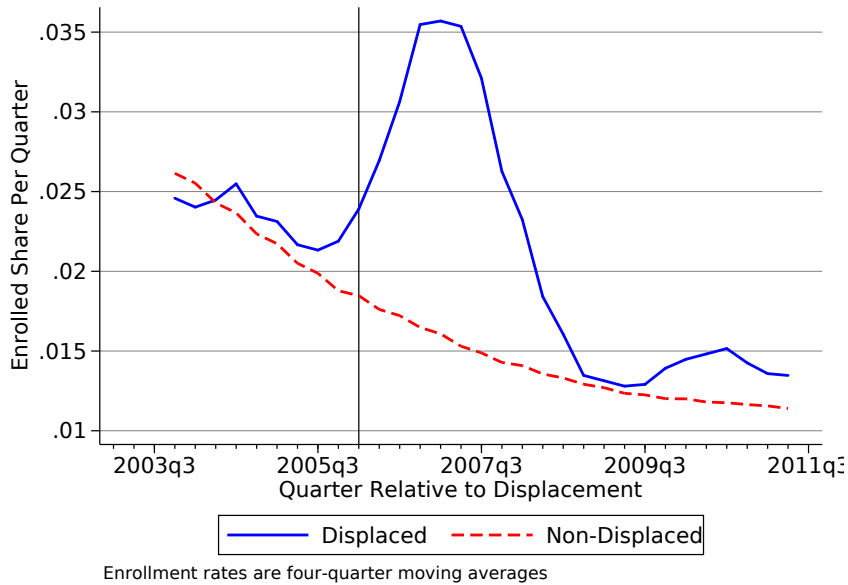

(a) Enrollment (point-in-time)

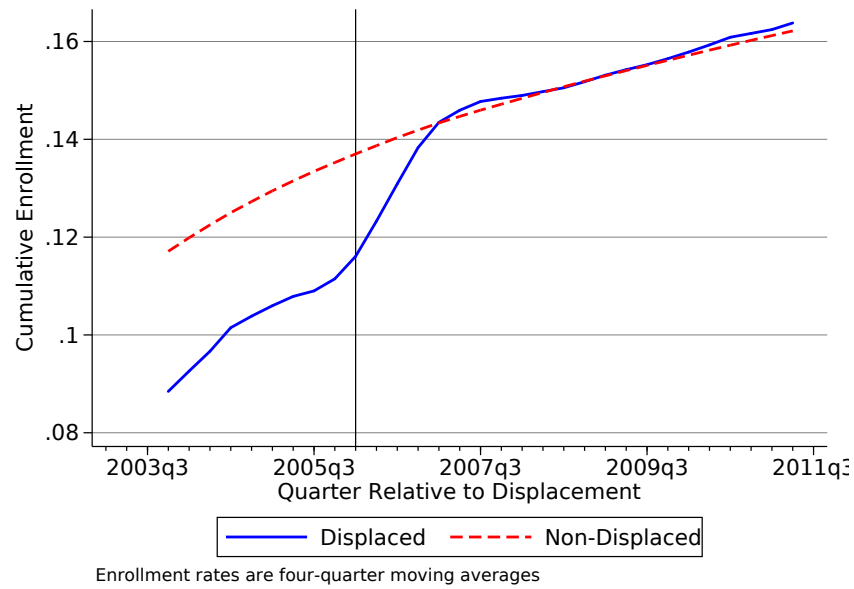

(b) Cumulative Enrollment

Note: Panels (a) and (b) plot the four-quarter moving averages of point-in-time and cumulative enrollment rates, respectively, for the cohort of workers displaced in 2006q1 and a comparison group attached to the labor force. 
Figure 3: Cumulative Effect of Displacement on Enrollment, Displaced 2002-2009

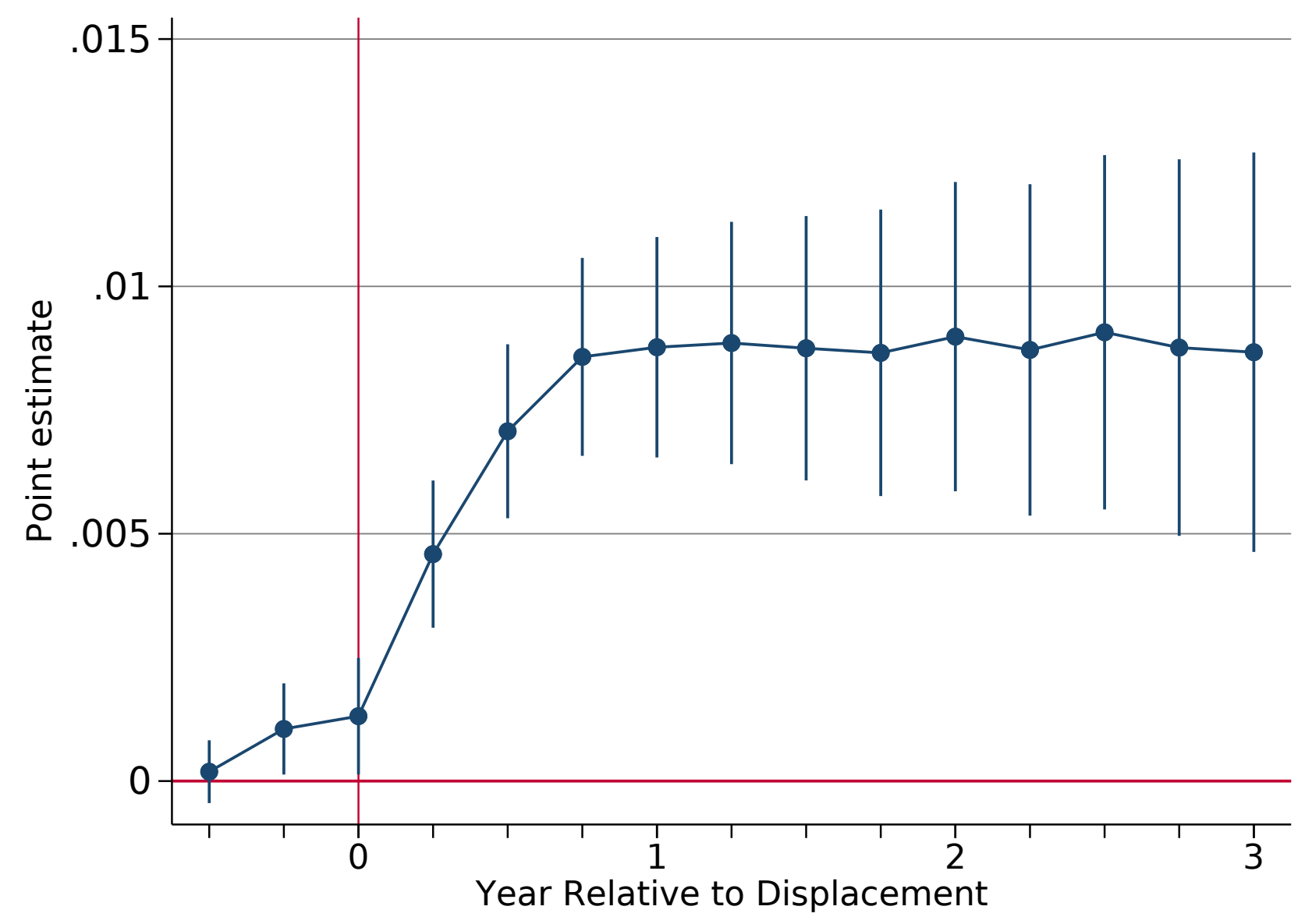

Note: Figure plots the estimated $\hat{\delta}_{k}$ 's from equation (1). Whiskers denote 95 -percent confidence intervals based on standard errors clustered by worker. Displaced sample is laid off between 2002q1 and 2009q4. Coefficients with standard errors are listed in Table 5. 
Figure 4: Cumulative Effect of Displacement on Enrollment by Industry of Layoff
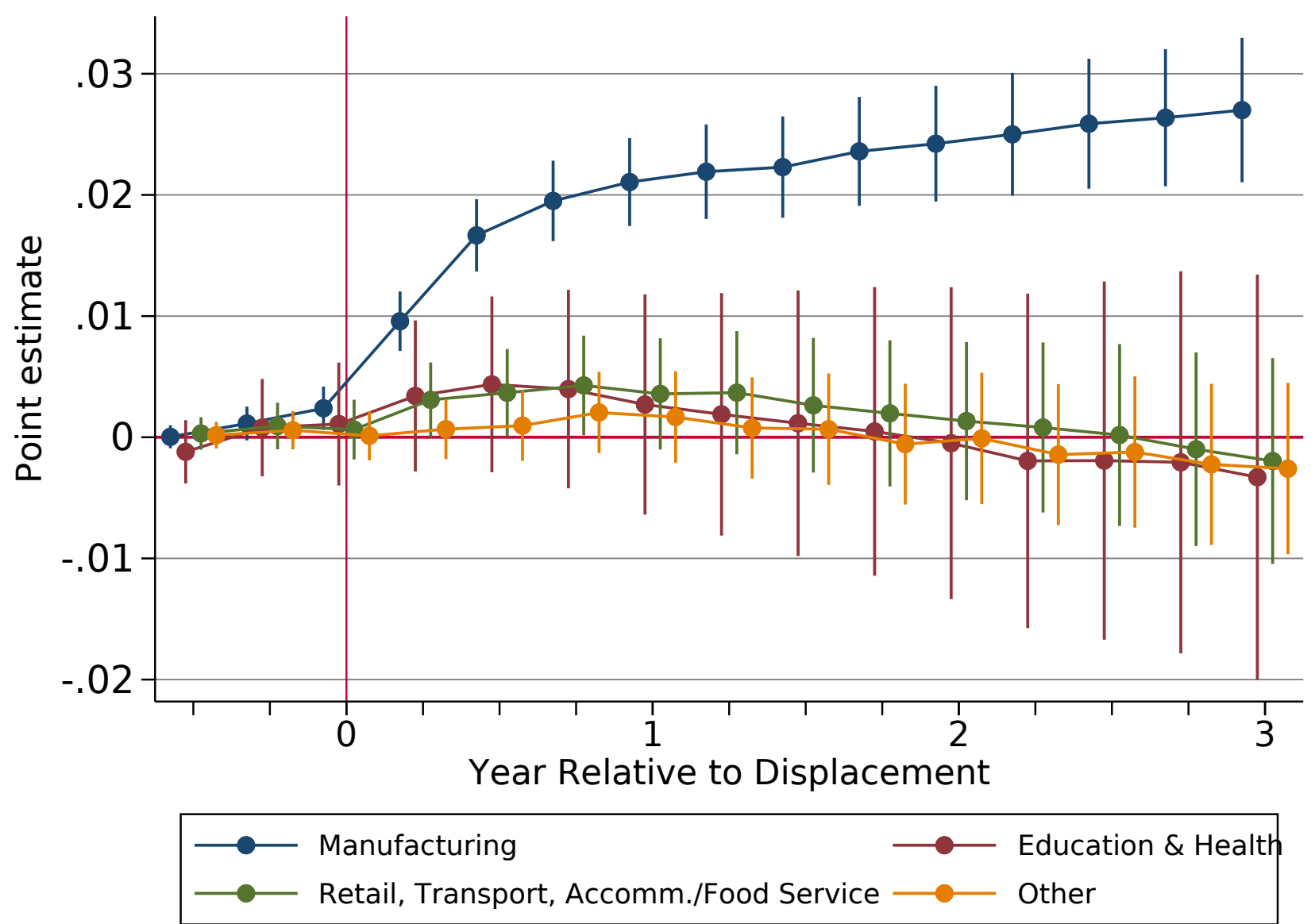

Note: Figure plots the $\hat{\delta}_{k}$ 's from equation (1) estimated separately for workers displaced from employers (or stably employed at) in manufacturing (23\% of displaced and comparison workers), education and health services $(24 \%)$, retail, wholesale, transport and warehousing, arts and entertainment, accommodations and food services (20\%), or other industries (33\%). Whiskers denote 95-percent confidence intervals based on standard errors clustered by worker. Displaced sample is laid off between 2002q1 and 2009q4. Point estimates and standard errors are listed in Appendix Table A.3. 
Figure 5: Cumulative Effect of Displacement from Manufacturing on Enrollment by Earnings Tercile within Layoff Firm

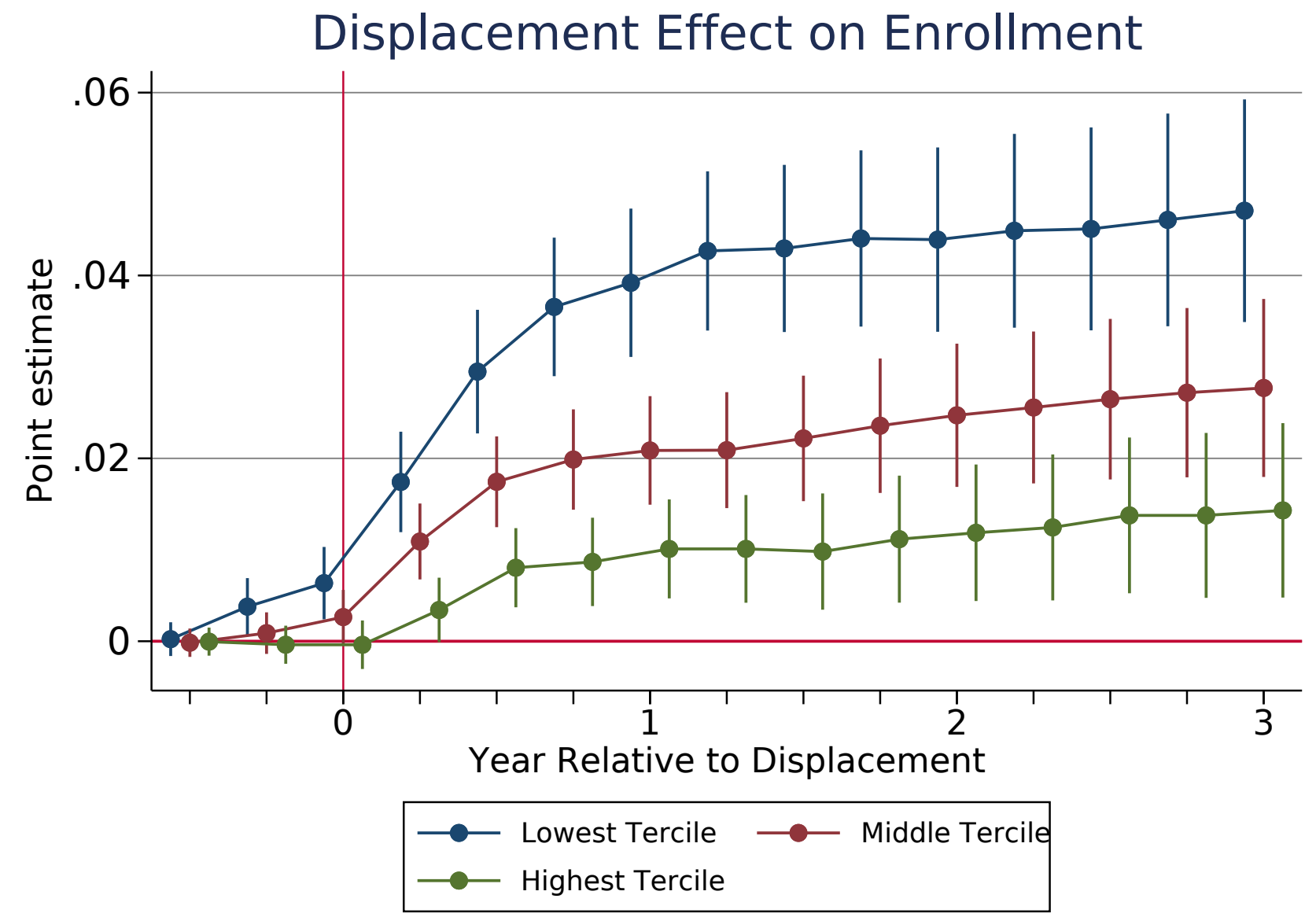

Note: Figure plots the $\hat{\delta}_{k}$ 's from equation (1) estimated separately for displaced manufacturing workers with earning in the lowest, middle, and highest tercile of their firm at the time of layoff. The comparison workers are similarly split by wage tercile and include those who were employed at a manufacturing firm for at least three consecutive years. Whiskers denote 95-percent confidence intervals based on standard errors clustered by worker. Displaced sample is laid off between 2002q1 and 2009q4. Displaced and comparison workers in the lowest, middle, and highest tercile comprise $20 \%, 35 \%$, and $45 \%$ of the manufacturing sample, respectively. Point estimates and standard errors are listed in Appendix Table A.4. 
Figure 6: Cumulative Effect of Displacement from Manufacturing on Enrollment by Local Labor Market Proximity to Public Higher Education

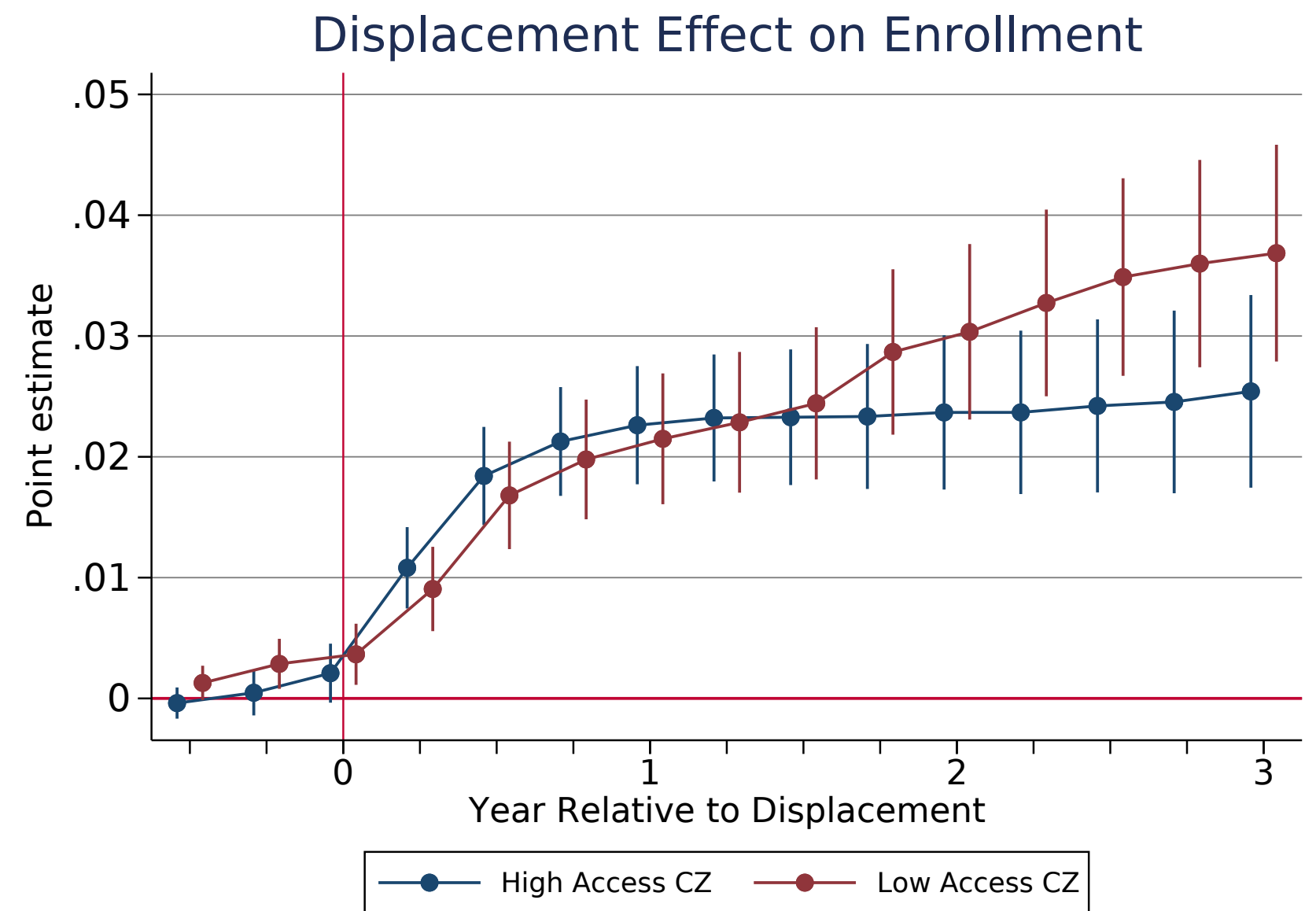

Note: Figure plots the $\hat{\delta}_{k}$ 's from equation (1) estimated separately for workers displaced from employers located in high vs. low college access commuting zones (CZs). Whiskers denote 95-percent confidence intervals based on standard errors clustered by worker. Displaced sample is laid off between 2002q1 and 2009q4. Point estimates and standard errors are listed in Appendix Table A.7. "High-access CZs" are those which host seven or more public institutions of higher education (four-year universities, branch campuses, community colleges, or technical colleges). Appendix Table B.1 lists each CZ's classification as high- or low-access with respect to public institutions. Workers displaced in the Parkersburg and Huntington, WV commuting zones are excluded because their CZs only include one Ohio county. $64 \%$ of displaced workers were laid off in high-access CZs and $36 \%$ from low-access CZs. 
Figure 7: Cumulative Effect of Displacement from Manufacturing on Enrollment by Proximity to Public and For-Profit Institutions
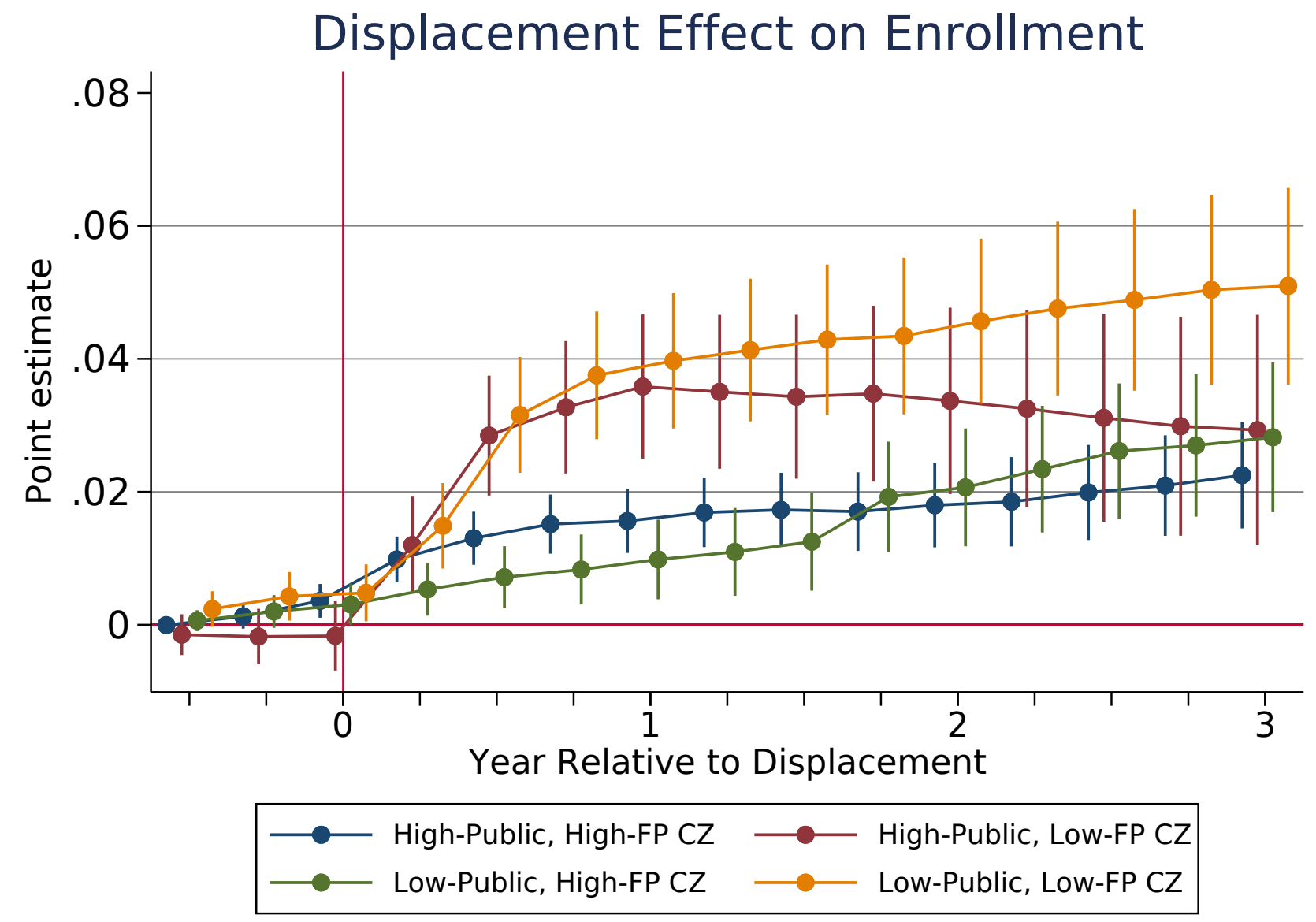

Note: Figure plots the $\hat{\delta}_{k}$ 's from equation (1) estimated separately for manufacturing workers displaced from employers located in commuting zones (CZs) classified by access to both public and for-profit college. CZs are divided according to public college access as in Figure 6, and then divided by high- and low- for-profit access within these groups according to locations of for-profits in 1999. "High-access public, high-access for-profit" CZs include Cincinnati, Cleveland, and Columbus (blue), representing $43 \%$ of the displaced manufacturing sample. "High-access public, low-access for-profit," including Dayton, Portsmouth, and Toledo (red), represents $21 \%$ of the sample. "Low-access public, high-access for-profit," including Canton, Lorain, and Youngstown (green), represents 22\% of the sample. "Low-access public, low-access for-profit," including Athens, Defiance, Findlay, Lima, Mansfield, Steubenville, Washington, Wheeling (WV), and Zanesville (yellow), represents 14\% of the sample. Workers displaced in the Parkersburg and Huntington, WV commuting zones are excluded because their CZs only include one Ohio county. Whiskers denote 95-percent confidence intervals based on standard errors clustered by worker. Displaced sample is laid off between 2002q1 and 2009q4. Point estimates and standard errors listed in Table A.8. 


\section{Appendix}

\section{A Further Results}

In Appendix A, we present further results and robustness checks for our paper's analysis.

\section{A.1 Tables Corresponding to Main Body}

Tables presenting point estimates and standard errors for regression results presented in Figures 4, 5, 6, and 7 are listed in this section. The tables are Table A.3, A.4, A.7 and A.8, respectively.

\section{A.2 Heterogeneity}

As a sensitivity check for our results in Figure 6, we conduct similar analysis at the county rather than commuting zone level. Specifically, we apply equation (1) when splitting samples according to whether manufacturing workers were employed (or laid off) in a county with a public community college (Figure A.5a). A list of community colleges and corresponding counties is provided in Table B.2. We find that workers displaced in "community college counties" are initially more likely to enroll than those without a community college in their county. After three years, however, the estimated effects on cumulative enrollment converge, such roughly 3 per every 100 displaced manufacturing workers pursue postsecondary training regardless of whether their county is home to a community college.

In Figure A.5b, we restrict this sample of displaced and comparison workers to those employed in counties without 4-year non-branch universities ("main universities" specified in Table B.3). Among these manufacturing employees for whom enrollment in a nearby 4-year university is less accessible due to geography, we estimate a larger enrollment response among those laid off in counties without a community college (4 per every 100 compared to 3 after three post-displacement years). We believe the results of Figures A.5a and A.5b, taken together, bolster our finding that increased proximity to public postsecondary institutions does not correlate with higher post-displacement enrollment.

Beyond heterogeneity explored in the main body of the text, in this section we investigate whether the effect of displacement on enrollment varied by other characteristics, including calendar quarter of layoff, firm size, and whether or not a firm shut down operations. Similar to the main text, we restrict our analysis to the subset of displaced workers laid off from manufacturing firms and comparison group workers who were employed for at least three years at a manufacturing plant.

If laid off between October and December, a worker may need to wait almost a full year to enroll if they want to start at the beginning of a school year, while those displaced between July and September may be able to start a new program immediately. This difference in season of layoff may change the individual's cost-benefit assessment and thus lead to differences in enrollment patterns. We examine this hypothesis in Figure A.2, which applies equation (1) separately to the workers displaced from manufacturing firms by calendar quarter of layoff and a common group of comparison manufacturing workers. Note that for this analysis, the quarter of layoff is defined as 
the last quarter of non-zero earnings at the displacement firm, such that a worker with non-zero earnings at the firm in Q3 and zero earnings at the firm in Q4 would be considered a Q3 layoff. The enrollment effects for displaced manufacturing workers are low across the board with limited seasonal variation. One year after job loss, between 1 and 2 out of every 100 manufacturing workers has been induced to enroll in public college regardless of calendar-quarter of layoff.

We also analyze enrollment patterns of workers by layoff firm characteristics, such as employer size and whether it fully shut down as opposed to implementing a mass layoff. One may speculate that firm size may have predictive power regarding how many displaced workers ultimately pursue postsecondary retraining. Historically, certain large firms have partnerships with local community colleges that may heighten workers' awareness of retraining options (Johnson, 1996; Roueche et al., 1995). Moreover, because large firms are subject to the Worker Adjustment and Retraining Notification (WARN) Act - which requires employers to provide at least 60 days of notice before plant closure or a mass layoff-affected employees could search for opportunities to enroll before separating from their job. ${ }^{21}$

To investigate this, we classify our displaced and non-displaced comparison samples by size of employer, designating a "large firm" and "small firm" group and applying equation (1) separately to each. We allow both 500 workers and 1,000 workers to serve as the cutoff for classification as a small or large firm. Figure A.3 underscores, however, that the size of the firm is not predictive of the share of displaced workers who are induced to enroll. In each case, roughly 2.5 per every 100 manufacturing workers enroll as a result of layoff.

Lastly, we study enrollment effects by firm shutdown status - proxied by a firm's unique identifier disappearing in the employer records or if employment level drops to zero - because many individuals' jobless spells end with "recall hires," reemployment at the firm from which they separated (Fujita and Moscarini, 2017; Albertini and Fairise, 2018). If newly-displaced workers expect to be recalled by their employers, they may be less likely to seek retraining to change occupations while jobless. ${ }^{22}$ In addition, examining firm shutdowns separately from mass layoffs may also address the identification concern that employers might non-randomly target specific workers for layoffs that may correlate with these workers' expected enrollment trends.

We apply equation (1) to the comparison group and the subset of displaced workers who lose their jobs in firm shutdowns, rather than simply any mass layoff. We classify displaced workers to have lost their job in a firm shutdown if they were employed within six quarters of a shutdown. We choose this window (as opposed to classifying only those workers who remain with the firm until the last period) because, in addition to the fact mass layoffs often occur in the months or years before a shutdown, many workers quit due to economic distress at the firm in anticipation of an impending shutdown (Flaaen et al., 2019). ${ }^{23}$ Figure A.4 compares the baseline estimates from specification (1)

\footnotetext{
${ }^{21}$ Specifically, WARN applies to employers with 100 or more employees (excluding new and seasonal workers) to provide at least 60 calendar days advance written notice of a plant closing and mass layoff affecting 50 or more employees at a single site of employment.

${ }^{22}$ According to Handwerker and Mason (2012), the Mass Layoff Statistics program documents that roughly half of firms which contracted substantially according to administrative data records reported that expected to recall some workers in the future.

${ }^{23}$ In the recent case of General Motors' Lordstown Assembly Complex in Lordstown, Ohio, GM first announced layoffs in November 2016 effective in 2017Q1. In 2018Q2, it announced a second wave of layoffs. Finally, in November 2018 GM announced its intention to close the Lordstown plant, which was idled in March 2019 (Maher, 2018; Lendel et al., 2019). For those Lordstown employees who left GM several months before March, while the proximate reason for separation may have been finding a new job, their ultimate reason for leaving was the firm distress and impending
} 
for the entire displaced sample with those for the subset of workers laid off in a firm shutdown $(26 \%$ of all displaced manufacturing workers). Similar to firm size, whether a firm shut down operations does not predict whether a worker subsequently enrolls in a public college.

\section{A.3 Other Measures and Specifications for Enrollment Effect}

As mentioned in Section 4, we estimate the effect of job displacement on postsecondary enrollment with variations of specification (1) as a robustness check.

The following equation is similar to (1) but omits worker-specific linear time trends.

$$
\text { cumul_enroll }_{i t}=\alpha_{i}+\gamma_{t}+W_{i t} \beta+\sum_{k=-2}^{12} \delta_{k} \cdot D_{i t k}+\varepsilon_{i t}
$$

Figure A.6 presents the point estimates and 95\% confidence intervals resulting from equation (2) applied to the overall sample of displaced and comparison workers. Three years post-layoff, this measure estimates that 2.5 per every 100 displaced workers subsequently enrolls in college compared to just 1 in our baseline estimates from equation (1).

We use transcript information to construct a cumulative measure of college credits attained, cumul_credit $_{i t}$, as a further robustness check for our finding that displacement has a limited but positive effect on public college enrollment. While cumul_enroll $_{i t}$ only assumes the values of 0 or 1, cumul_credit ${ }_{i t}$ is a cumulative and unbounded above.

$$
\text { cumul_credit }_{i t}=\alpha_{i}+\gamma_{t}+\lambda_{i} \cdot t+W_{i t} \beta+\sum_{k=-2}^{12} \delta_{k} \cdot D_{i t k}+\varepsilon_{i t}
$$

Figure A.7 presents the results of equation (3) applied to the overall displaced and comparison sample. While we estimate virtually no effect in the quarters leading up to job loss, just one year after separation, roughly 12 college credits have been attained by displaced workers for every 100 laid off. After three years, this effect rises to over 30 credits. Figure A.7 suggests a reasonable degree of enrollment persistence. However, given a typical college course amounts to 3 credits, we consider this further evidence that the effect of displacement on enrollment is fairly limited.

Lastly, we use a shorter time horizon and a point-in-time measure of enrollment, enroll ${ }_{i t}$, as a dependent variable in equation 4. Figure A.8 presents the results.

$$
\text { enroll }_{i t}=\alpha_{i}+\gamma_{t}+\lambda_{i} \cdot t+W_{i t} \beta+\sum_{k=-2}^{12} \delta_{k} \cdot D_{i t k}+\varepsilon_{i t}
$$

While displacement does not have a statistically significant effect on postsecondary enrollment during the calendar-quarter of layoff, we estimate a positive effect in the following quarters. The effect peaks in the third full post-layoff quarter and fades to near-zero after two years. Using the point-in-time enrollment measure, we estimate that three quarters after layoff, 1 worker for every 100 displaced enrolled was enrolled in college as a result.

shutdown. 
Table A.1: Industry of Displacement by Calendar Quarter of Layoff

\begin{tabular}{lcccc}
\hline & \multicolumn{4}{c}{ Quarter of Displacement } \\
& 1st & 2nd & 3rd & 4th \\
\hline Industry & & & & \\
Construction, Utilities, Mining & 0.087 & 0.120 & 0.115 & 0.118 \\
Manufacturing & 0.403 & 0.297 & 0.329 & 0.201 \\
Retail Trade & 0.098 & 0.126 & 0.081 & 0.147 \\
Transportation \& Warehousing & 0.016 & 0.039 & 0.033 & 0.019 \\
Finance, Insurance, Real Estate & 0.046 & 0.038 & 0.052 & 0.215 \\
Educational \& Health Services & 0.111 & 0.081 & 0.078 & 0.061 \\
Hospitality \& Food Services & 0.029 & 0.046 & 0.064 & 0.047 \\
Other & 0.210 & 0.253 & 0.248 & 0.192 \\
\hline$N$ & 15,151 & 15,442 & 15,095 & 22,859 \\
\hline \hline
\end{tabular}

Note: Table lists the share of workers displaced from different industries during a given calendar quarter. The 1st quarter corresponds to a mass layoff during January-March. The 2nd quarter is April-June, the 3rd quarter is July-September, and the 4th quarter is October-December. 
Table A.2: Displaced Worker Descriptive Statistics by Firm Shutdown Status

\begin{tabular}{lcc}
\hline & $\begin{array}{c}\text { Displaced in Firm Shutdown } \\
\text { Yes }\end{array}$ & No \\
\hline Industry of Layoff & & \\
Construction, Utilities, Mining & 0.112 & 0.111 \\
Manufacturing & 0.278 & 0.297 \\
Retail Trade & 0.268 & 0.063 \\
Transportation \& Warehousing & 0.018 & 0.028 \\
Finance, Insurance, Real Estate & 0.044 & 0.129 \\
Educational \& Health Services & 0.072 & 0.083 \\
Hospitality \& Food Services & 0.041 & 0.048 \\
Other & 0.167 & 0.241 \\
Yearly Pre-Layoff Earnings & & \\
1-4 Quarters Before (\$) & 44,837 & 51,746 \\
& $(34,619)$ & $(40,398)$ \\
Firm Characteristics & & \\
Average Number of Employees & 846 & 1,463 \\
Std. Dev. of Yearly Earnings $(\$)$ & 30,582 & 39,923 \\
Median Annual Earnings $(\$)$ & 32,950 & 43,957 \\
\hline$N$ & 17,281 & 51,266 \\
\hline \hline
\end{tabular}

Note: Table lists the share of workers displaced between 2002q1 and 2009q4 from different industries by whether or not they were laid off in a firm shutdown. Standard deviation of pre-displacement earnings is in parentheses. Earnings are in inflation-adjusted to USD $\$ 2012$ using the CPI-U. 
Table A.3: Cumulative Effect of Displacement on Enrollment by Layoff Industry

\begin{tabular}{|c|c|c|c|c|}
\hline & Manufacturing & Educ/Health & RWTAEFA & Other \\
\hline \multicolumn{5}{|c|}{ Quarter rel. to displacement } \\
\hline-2 & 0.0000 & $\begin{array}{l}-0.0012 \\
(0.0013)\end{array}$ & $\begin{array}{l}0.0003 \\
(00007)\end{array}$ & $\begin{array}{c}0.0002 \\
(0.0006)\end{array}$ \\
\hline \multirow{2}{*}{-1} & 0.0011 & 0.0008 & 0.0009 & 0.0006 \\
\hline & $(0.0007)$ & $(0.0020)$ & $(0.0010)$ & $(0.0008)$ \\
\hline \multirow[t]{2}{*}{0} & $0.0024^{* *}$ & 0.0011 & 0.0006 & 0.0001 \\
\hline & $(0.0009)$ & $(0.0026)$ & $(0.0013)$ & $(0.0010)$ \\
\hline \multirow[t]{2}{*}{1} & $0.0096^{* * *}$ & 0.0034 & $0.0031^{*}$ & 0.0007 \\
\hline & $(0.0013)$ & $(0.0032)$ & $(0.0016)$ & $(0.0013)$ \\
\hline \multirow[t]{2}{*}{2} & $0.0167^{* * *}$ & 0.0044 & $0.0037^{*}$ & 0.0010 \\
\hline & $(0.0015)$ & $(0.0037)$ & $(0.0018)$ & $(0.0015)$ \\
\hline \multirow[t]{2}{*}{3} & $0.0195^{* * *}$ & 0.0040 & $0.0043^{*}$ & 0.0020 \\
\hline & $(0.0017)$ & $(0.0042)$ & $(0.0021)$ & $(0.0017)$ \\
\hline \multirow[t]{2}{*}{4} & $0.0211^{* * *}$ & 0.0027 & 0.0036 & 0.0017 \\
\hline & $(0.0018)$ & $(0.0046)$ & $(0.0023)$ & $(0.0019)$ \\
\hline \multirow[t]{2}{*}{5} & $0.0219^{* * *}$ & 0.0019 & 0.0037 & 0.0008 \\
\hline & $(0.0020)$ & $(0.0051)$ & $(0.0026)$ & $(0.0021)$ \\
\hline \multirow[t]{2}{*}{6} & $0.0223^{* * *}$ & 0.0012 & 0.0026 & 0.0007 \\
\hline & $(0.0021)$ & $(0.0056)$ & $(0.0028)$ & $(0.0023)$ \\
\hline \multirow[t]{2}{*}{7} & $0.0236^{* * *}$ & 0.0005 & 0.0020 & -0.0006 \\
\hline & $(0.0023)$ & $(0.0061)$ & $(0.0031)$ & $(0.0025)$ \\
\hline \multirow[t]{2}{*}{8} & $0.0242^{* * *}$ & -0.0005 & 0.0013 & -0.0001 \\
\hline & $(0.0024)$ & $(0.0066)$ & $(0.0033)$ & $(0.0028)$ \\
\hline \multirow[t]{2}{*}{9} & $0.0250^{* * *}$ & -0.0019 & 0.0008 & -0.0014 \\
\hline & $(0.0026)$ & $(0.0070)$ & $(0.0036)$ & $(0.0030)$ \\
\hline \multirow[t]{2}{*}{10} & $0.0259^{* * *}$ & -0.0019 & 0.0002 & -0.0012 \\
\hline & $(0.0027)$ & $(0.0075)$ & $(0.0038)$ & $(0.0032)$ \\
\hline \multirow[t]{2}{*}{11} & $0.0264^{* * *}$ & -0.0021 & -0.0010 & -0.0022 \\
\hline & $(0.0029)$ & $(0.0080)$ & $(0.0041)$ & $(0.0034)$ \\
\hline \multirow[t]{2}{*}{12} & $0.0270^{* * *}$ & -0.0033 & -0.0020 & -0.0026 \\
\hline & $(0.0030)$ & $(0.0085)$ & $(0.0043)$ & $(0.0036)$ \\
\hline Observations & $10,362,772$ & $10,450,584$ & $8,992,820$ & $14,485,012$ \\
\hline
\end{tabular}

Note: Standard errors in parentheses; ${ }^{*} p<0.05,{ }^{* *} p<0.01,{ }^{* * *} p<0.001$; RWTAEFA: Retail, Wholesale, Transportation \& Warehousing, Arts \& Entertainment and Food \& Accommodation 
Table A.4: Cumulative Effect of Displacement from Manufacturing on Enrollment by Within-Firm Tercile of Earnings

\begin{tabular}{|c|c|c|c|}
\hline Quarter rel. to displacement & Lowest & Middle & Highest \\
\hline-2 & $\begin{array}{c}0.0002 \\
(0.0009)\end{array}$ & $\begin{array}{l}-0.0002 \\
(0.0008)\end{array}$ & $\begin{array}{l}-0.0000 \\
(0.0008)\end{array}$ \\
\hline-1 & $\begin{array}{l}0.0038^{*} \\
(0.0016)\end{array}$ & $\begin{array}{c}0.0009 \\
(0.0012)\end{array}$ & $\begin{array}{l}-0.0004 \\
(0.0011)\end{array}$ \\
\hline 0 & $\begin{array}{c}0.0064^{* *} \\
(0.0020)\end{array}$ & $\begin{array}{c}0.0026 \\
(0.0015)\end{array}$ & $\begin{array}{l}-0.0004 \\
(0.0014)\end{array}$ \\
\hline 1 & $\begin{array}{c}0.0174^{* * *} \\
(0.0028)\end{array}$ & $\begin{array}{c}0.0109^{* * *} \\
(0.0021)\end{array}$ & $\begin{array}{c}0.0034 \\
(0.0018)\end{array}$ \\
\hline 2 & $\begin{array}{c}0.0295^{* * *} * \\
(0.0034)\end{array}$ & $\begin{array}{c}0.0174^{* * *} \\
(0.0025)\end{array}$ & $\begin{array}{c}0.0080^{* * * *} \\
(0.0022)\end{array}$ \\
\hline 3 & $\begin{array}{c}0.0366^{* * *} \\
(0.0039)\end{array}$ & $\begin{array}{c}0.0199 * * * \\
(0.0028)\end{array}$ & $\begin{array}{c}0.0087^{* * *} \\
(0.0025)\end{array}$ \\
\hline 4 & $\begin{array}{c}0.0392^{* * *} \\
(0.0041)\end{array}$ & $\begin{array}{c}0.0209^{* * *} \\
(0.0030)\end{array}$ & $\begin{array}{c}0.0101^{* * *} \\
(0.0028)\end{array}$ \\
\hline 5 & $\begin{array}{c}0.0427^{* * *} \\
(0.0044)\end{array}$ & $\begin{array}{c}0.0209^{* * * *} \\
(0.0032)\end{array}$ & $\begin{array}{c}0.0101^{* * *} \\
(0.0030)\end{array}$ \\
\hline 6 & $\begin{array}{c}0.0430^{* * * *} \\
(0.0047)\end{array}$ & $\begin{array}{c}0.0222^{* * * *} \\
(0.0035)\end{array}$ & $\begin{array}{c}0.0098^{* *} \\
(0.0032)\end{array}$ \\
\hline 7 & $\begin{array}{c}0.0440^{* * *} \\
(0.0049)\end{array}$ & $\begin{array}{c}0.0236^{* * * *} \\
(0.0038)\end{array}$ & $\begin{array}{c}0.0112^{* *} \\
(0.0035)\end{array}$ \\
\hline 8 & $\begin{array}{c}0.0439 * * * \\
(0.0051)\end{array}$ & $\begin{array}{c}0.0247^{* * *} \\
(0.0040)\end{array}$ & $\begin{array}{c}0.0119^{* *} \\
(0.0038)\end{array}$ \\
\hline 9 & $\begin{array}{c}0.0449^{* * * *} \\
(0.0054)\end{array}$ & $\begin{array}{c}0.0256^{* * *} \\
(0.0042)\end{array}$ & $\begin{array}{c}0.0124^{* *} \\
(0.0041)\end{array}$ \\
\hline 10 & $\begin{array}{c}0.0451^{* * * *} \\
(0.0057)\end{array}$ & $\begin{array}{c}0.0265^{* * *} \\
(0.0045)\end{array}$ & $\begin{array}{c}0.0138^{* *} \\
(0.0043)\end{array}$ \\
\hline 11 & $\begin{array}{c}0.0461^{* * * *} \\
(0.0059)\end{array}$ & $\begin{array}{c}0.0272^{* * * *} \\
(0.0047)\end{array}$ & $\begin{array}{c}0.0138^{* *} \\
(0.0046)\end{array}$ \\
\hline 12 & $\begin{array}{c}0.0471^{* * *} \\
(0.0062)\end{array}$ & $\begin{array}{c}0.0277^{* * *} \\
(0.0050)\end{array}$ & $\begin{array}{c}0.0143^{* *} \\
(0.0049)\end{array}$ \\
\hline Observations & $2,212,479$ & $4,000,350$ & $5,192,558$ \\
\hline
\end{tabular}

Note: Standard errors in parentheses; ${ }^{*} p<0.05,{ }^{* *} p<0.01,{ }^{* * *} p<0.001$; Samples are divided by within-firm tercile of earnings in 2005Q1 (for comparison group) or in the quarter prior to displacement (for displaced group). 
Table A.5: Cumulative Effect of Displacement from Manufacturing on Enrollment by Earnings Relative to Firm Median

\begin{tabular}{|c|c|c|}
\hline Quarter rel. to displacement & Below Median & Above Median \\
\hline-2 & $\begin{array}{c}0.0003 \\
(0.0007)\end{array}$ & $\begin{array}{l}-0.0001 \\
(0.0006)\end{array}$ \\
\hline-1 & $\begin{array}{l}0.0027^{*} \\
(0.0012)\end{array}$ & $\begin{array}{c}0.0000 \\
(0.0009)\end{array}$ \\
\hline 0 & $\begin{array}{c}0.0048^{* *} \\
(0.0015)\end{array}$ & $\begin{array}{c}0.0006 \\
(0.0011)\end{array}$ \\
\hline 1 & $\begin{array}{c}0.0155^{* * *} \\
(0.0021)\end{array}$ & $\begin{array}{c}0.0052^{* * *} \\
(0.0015)\end{array}$ \\
\hline 2 & $\begin{array}{c}0.0249^{* * *} \\
(0.0025)\end{array}$ & $\begin{array}{c}0.0106^{* * *} \\
(0.0019)\end{array}$ \\
\hline 3 & $\begin{array}{c}0.0298^{* * *} \\
(0.0028)\end{array}$ & $\begin{array}{c}0.0118^{* * *} \\
(0.0021)\end{array}$ \\
\hline 4 & $\begin{array}{c}0.0311^{* * *} \\
(0.0030)\end{array}$ & $\begin{array}{c}0.0136^{* * *} \\
(0.0023)\end{array}$ \\
\hline 5 & $\begin{array}{c}0.0335^{* * *} \\
(0.0032)\end{array}$ & $\begin{array}{c}0.0133^{* * *} \\
(0.0025)\end{array}$ \\
\hline 6 & $\begin{array}{c}0.0345^{* * *} \\
(0.0034)\end{array}$ & $\begin{array}{c}0.0133^{* * *} \\
(0.0027)\end{array}$ \\
\hline 7 & $\begin{array}{c}0.0354^{* * *} \\
(0.0036)\end{array}$ & $\begin{array}{c}0.0149^{* * *} \\
(0.0029)\end{array}$ \\
\hline 8 & $\begin{array}{c}0.0352^{\text {*** }} \\
(0.0038)\end{array}$ & $\begin{array}{c}0.0162^{* * *} \\
(0.0031)\end{array}$ \\
\hline 9 & $\begin{array}{c}0.0362^{* * *} \\
(0.0040)\end{array}$ & $\begin{array}{c}0.0168^{* * * *} \\
(0.0034)\end{array}$ \\
\hline 10 & $\begin{array}{c}0.0366^{* * * *} \\
(0.0042)\end{array}$ & $\begin{array}{c}0.0180^{* * *} \\
(0.0036)\end{array}$ \\
\hline 11 & $\begin{array}{c}0.0374^{* * *} \\
(0.0045)\end{array}$ & $\begin{array}{c}0.0183^{* * *} * \\
(0.0038)\end{array}$ \\
\hline 12 & $\begin{array}{c}0.0380^{* * * *} \\
(0.0047)\end{array}$ & $\begin{array}{c}0.0189^{* * *} \\
(0.0040)\end{array}$ \\
\hline Observations & $4,158,847$ & $7,246,640$ \\
\hline
\end{tabular}

Note: Standard errors in parentheses; ${ }^{*} p<0.05,{ }^{* *} p<0.01,{ }^{* * *} p<0.001$; Samples are divided by within-firm tercile of earnings in 2005Q1 (for comparison group) or in the quarter prior to displacement (for displaced group). 
Table A.6: Cumulative Effect of Displacement from Manufacturing on Enrollment by Within-Firm Quartile of Earnings

\begin{tabular}{|c|c|c|c|c|}
\hline Quarter rel. to displacement & Lowest Quartile & 2nd Quartile & 3rd Quartile & 4th Quartile \\
\hline-2 & $\begin{array}{c}0.0003 \\
(0.0013)\end{array}$ & $\begin{array}{c}0.0000 \\
(0.0009)\end{array}$ & $\begin{array}{c}-0.0001 \\
(0.0009)\end{array}$ & $\begin{array}{l}-0.0002 \\
(0.0009)\end{array}$ \\
\hline-1 & $\begin{array}{c}0.0031 \\
(0.0020)\end{array}$ & $\begin{array}{c}0.0022 \\
(0.0014)\end{array}$ & $\begin{array}{c}0.0006 \\
(0.0013)\end{array}$ & $\begin{array}{l}-0.0006 \\
(0.0012)\end{array}$ \\
\hline 0 & $\begin{array}{c}0.0066^{*} \\
(0.0026)\end{array}$ & $\begin{array}{l}0.0035^{*} \\
(0.0018)\end{array}$ & $\begin{array}{c}0.0022 \\
(0.0017)\end{array}$ & $\begin{array}{c}-0.0011 \\
(0.0016)\end{array}$ \\
\hline 1 & $\begin{array}{c}0.0175^{* * *} \\
(0.0035)\end{array}$ & $\begin{array}{c}0.0141^{* * * *} \\
(0.0026)\end{array}$ & $\begin{array}{c}0.0081^{* * *} * \\
(0.0022)\end{array}$ & $\begin{array}{c}0.0021 \\
(0.0021)\end{array}$ \\
\hline 2 & $\begin{array}{c}0.0308^{* * *} \\
(0.0044)\end{array}$ & $\begin{array}{c}0.0210 * * * \\
(0.0031)\end{array}$ & $\begin{array}{c}0.0142 * * * \\
(0.0027)\end{array}$ & $\begin{array}{c}0.0068^{* *} \\
(0.0026)\end{array}$ \\
\hline 3 & $\begin{array}{c}0.0372^{* * *} \\
(0.0049)\end{array}$ & $\begin{array}{c}0.0251^{* * *} \\
(0.0034)\end{array}$ & $\begin{array}{c}0.0165^{* * *} \\
(0.0030)\end{array}$ & $\begin{array}{l}0.0070^{*} \\
(0.0029)\end{array}$ \\
\hline 4 & $\begin{array}{c}0.0399^{* * *} \\
(0.0053)\end{array}$ & $\begin{array}{c}0.0255^{* * *} \\
(0.0036)\end{array}$ & $\begin{array}{c}0.0190 * * * \\
(0.0033)\end{array}$ & $\begin{array}{l}0.0081^{*} \\
(0.0033)\end{array}$ \\
\hline 5 & $\begin{array}{c}0.0427^{* * *} * \\
(0.0056)\end{array}$ & $\begin{array}{c}0.0276^{* * *} \\
(0.0039)\end{array}$ & $\begin{array}{c}0.0182^{* * *} \\
(0.0035)\end{array}$ & $\begin{array}{l}0.0084^{*} \\
(0.0036)\end{array}$ \\
\hline 6 & $\begin{array}{c}0.0430^{* * *} \\
(0.0060)\end{array}$ & $\begin{array}{c}0.0291 * * * \\
(0.0042)\end{array}$ & $\begin{array}{c}0.0186^{* * *} \\
(0.0037)\end{array}$ & $\begin{array}{l}0.0078^{*} \\
(0.0039)\end{array}$ \\
\hline 7 & $\begin{array}{c}0.0438^{* * *} \\
(0.0063)\end{array}$ & $\begin{array}{c}0.0300^{* * *} \\
(0.0044)\end{array}$ & $\begin{array}{c}0.0207^{* * *} \\
(0.0040)\end{array}$ & $\begin{array}{l}0.0090^{*} \\
(0.0043)\end{array}$ \\
\hline 8 & $\begin{array}{c}0.0438^{* * *} \\
(0.0066)\end{array}$ & $\begin{array}{c}0.0297^{* * *} * \\
(0.0047)\end{array}$ & $\begin{array}{c}0.0229 * * * \\
(0.0043)\end{array}$ & $\begin{array}{c}0.0093^{*} \\
(0.0046)\end{array}$ \\
\hline 9 & $\begin{array}{c}0.0447^{* * *} \\
(0.0070)\end{array}$ & $\begin{array}{c}0.0308^{* * *} \\
(0.0049)\end{array}$ & $\begin{array}{c}0.0243^{* * *} \\
(0.0046)\end{array}$ & $\begin{array}{c}0.0091 \\
(0.0049)\end{array}$ \\
\hline 10 & $\begin{array}{c}0.0451^{* * *} \\
(0.0073)\end{array}$ & $\begin{array}{c}0.0313^{* * *} \\
(0.0052)\end{array}$ & $\begin{array}{c}0.0267^{* * *} \\
(0.0048)\end{array}$ & $\begin{array}{c}0.0092 \\
(0.0052)\end{array}$ \\
\hline 11 & $\begin{array}{c}0.0453^{* * *} \\
(0.0077)\end{array}$ & $\begin{array}{c}0.0324^{* * *} \\
(0.0055)\end{array}$ & $\begin{array}{c}0.0273^{* * *} \\
(0.0051)\end{array}$ & $\begin{array}{c}0.0092 \\
(0.0056)\end{array}$ \\
\hline 12 & $\begin{array}{c}0.0451^{* * *} \\
(0.0080)\end{array}$ & $\begin{array}{c}0.0336^{* * *} \\
(0.0058)\end{array}$ & $\begin{array}{c}0.0283^{* * *} \\
(0.0054)\end{array}$ & $\begin{array}{c}0.0095 \\
(0.0059)\end{array}$ \\
\hline Observations & $1,460,934$ & $2,697,813$ & $3,374,825$ & $3,871,815$ \\
\hline
\end{tabular}

Note: Standard errors in parentheses; ${ }^{*} p<0.05,{ }^{* *} p<0.01,{ }^{* * *} p<0.001$; Samples are divided by within-firm tercile of earnings in 2005Q1 (for comparison group) or in the quarter prior to displacement (for displaced group). 
Table A.7: Cumulative Effect of Displacement from Manufacturing on Enrollment by Local Labor Market Proximity to Public Higher Education

\begin{tabular}{|c|c|c|}
\hline Quarter rel. to displacement & High-Access & Low-Access \\
\hline-2 & $\begin{array}{l}-0.0004 \\
(0.0007)\end{array}$ & $\begin{array}{c}0.0013 \\
(0.0007)\end{array}$ \\
\hline-1 & $\begin{array}{c}0.0005 \\
(0.0010)\end{array}$ & $\begin{array}{c}0.0029 * * \\
(0.0011)\end{array}$ \\
\hline 0 & $\begin{array}{c}0.0021 \\
(0.0012)\end{array}$ & $\begin{array}{c}0.0037^{* *} \\
(0.0013)\end{array}$ \\
\hline 1 & $\begin{array}{c}0.0108^{* * *} \\
(0.0017)\end{array}$ & $\begin{array}{c}0.0091 * * * \\
(0.0018)\end{array}$ \\
\hline 2 & $\begin{array}{c}0.0184^{* * *} \\
(0.0021)\end{array}$ & $\begin{array}{c}0.0168^{* * *} \\
(0.0023)\end{array}$ \\
\hline 3 & $\begin{array}{c}0.0213^{* * *} \\
(0.0023)\end{array}$ & $\begin{array}{c}0.0198 * * * \\
(0.0025)\end{array}$ \\
\hline 4 & $\begin{array}{c}0.0226^{* * *} \\
(0.0025)\end{array}$ & $\begin{array}{c}0.0215^{* * *} \\
(0.0028)\end{array}$ \\
\hline 5 & $\begin{array}{c}0.0232^{* * *} \\
(0.0027)\end{array}$ & $\begin{array}{c}0.0229 * * * \\
(0.0030)\end{array}$ \\
\hline 6 & $\begin{array}{c}0.0233^{* * *} \\
(0.0029)\end{array}$ & $\begin{array}{c}0.0244^{* * *} \\
(0.0032)\end{array}$ \\
\hline 7 & $\begin{array}{c}0.0233^{* * *} \\
(0.0031)\end{array}$ & $\begin{array}{c}0.0287^{* * *} \\
(0.0035)\end{array}$ \\
\hline 8 & $\begin{array}{c}0.0237^{* * *} \\
(0.0033)\end{array}$ & $\begin{array}{c}0.0303^{* * *} \\
(0.0037)\end{array}$ \\
\hline 9 & $\begin{array}{c}0.0237^{* * *} \\
(0.0035)\end{array}$ & $\begin{array}{c}0.0327^{* * *} \\
(0.0039)\end{array}$ \\
\hline 10 & $\begin{array}{c}0.0242^{* * *} \\
(0.0037)\end{array}$ & $\begin{array}{c}0.0349^{* * *} * \\
(0.0042)\end{array}$ \\
\hline 11 & $\begin{array}{c}0.0245^{* * *} \\
(0.0039)\end{array}$ & $\begin{array}{c}0.0360^{* * *} \\
(0.0044)\end{array}$ \\
\hline 12 & $\begin{array}{c}0.0254^{* * *} \\
(0.0041)\end{array}$ & $\begin{array}{c}0.0369^{* * *} * \\
(0.0046)\end{array}$ \\
\hline Observations & $8,233,008$ & $3,844,001$ \\
\hline
\end{tabular}

Note: Standard errors in parentheses; ${ }^{*} p<0.05,{ }^{* *} p<0.01,{ }^{* * *} p<0.001$; Samples are divided by within-firm tercile of earnings in 2005Q1 (for comparison group) or in the quarter prior to displacement (for displaced group). 
Table A.8: Cumulative Effect of Displacement from Manufacturing on Enrollment by Local Labor Market Proximity to Public and For-Profit Higher Education

\begin{tabular}{|c|c|c|c|c|}
\hline $\begin{array}{l}\text { Quarter rel. } \\
\text { to displacement }\end{array}$ & $\begin{array}{l}\text { High-Public } \\
\text { High-FP }\end{array}$ & $\begin{array}{l}\text { High-Public } \\
\text { Low-FP }\end{array}$ & $\begin{array}{c}\text { Low-Public } \\
\text { High-FP }\end{array}$ & $\begin{array}{c}\text { Low-Public } \\
\text { Low-FP }\end{array}$ \\
\hline-2 & $\begin{array}{l}-0.0001 \\
(0.0006)\end{array}$ & $\begin{array}{l}-0.0015 \\
(0.0016)\end{array}$ & $\begin{array}{c}0.0006 \\
(0.0008)\end{array}$ & $\begin{array}{c}0.0024 \\
(0.0014)\end{array}$ \\
\hline-1 & $\begin{array}{c}0.0013 \\
(0.0009)\end{array}$ & $\begin{array}{l}-0.0018 \\
(0.0021)\end{array}$ & $\begin{array}{c}0.0020 \\
(0.0013)\end{array}$ & $\begin{array}{l}0.0043^{*} \\
(0.0019)\end{array}$ \\
\hline 0 & $\begin{array}{c}0.0036^{* *} \\
(0.0013)\end{array}$ & $\begin{array}{l}-0.0017 \\
(0.0027)\end{array}$ & $\begin{array}{c}0.0031 \\
(0.0016)\end{array}$ & $\begin{array}{l}0.0048^{*} \\
(0.0022)\end{array}$ \\
\hline 1 & $\begin{array}{c}0.0098 * * * \\
(0.0018)\end{array}$ & $\begin{array}{l}0.0120^{* *} \\
(0.0037)\end{array}$ & $\begin{array}{l}0.0053^{* *} \\
(0.0020)\end{array}$ & $\begin{array}{c}0.0149^{* * *} \\
(0.0033)\end{array}$ \\
\hline 2 & $\begin{array}{c}0.0130 * * * \\
(0.0020)\end{array}$ & $\begin{array}{c}0.0285^{* * *} \\
(0.0046)\end{array}$ & $\begin{array}{l}0.0072^{* *} \\
(0.0024)\end{array}$ & $\begin{array}{c}0.0316^{* * *} \\
(0.0044)\end{array}$ \\
\hline 3 & $\begin{array}{c}0.0151^{* * *} \\
(0.0023)\end{array}$ & $\begin{array}{c}0.0327^{* * *} \\
(0.0051)\end{array}$ & $\begin{array}{l}0.0083^{* *} \\
(0.0027)\end{array}$ & $\begin{array}{c}0.0375^{* * *} \\
(0.0049)\end{array}$ \\
\hline 4 & $\begin{array}{c}0.0156^{* * *} \\
(0.0025)\end{array}$ & $\begin{array}{c}0.0358^{* * *} \\
(0.0055)\end{array}$ & $\begin{array}{l}0.0098 * * \\
(0.0031)\end{array}$ & $\begin{array}{c}0.0397^{* * *} \\
(0.0052)\end{array}$ \\
\hline 5 & $\begin{array}{c}0.0169^{* * *} \\
(0.0027)\end{array}$ & $\begin{array}{c}0.0350 * * * \\
(0.0059)\end{array}$ & $\begin{array}{c}0.0110^{* *} \\
(0.0034)\end{array}$ & $\begin{array}{c}0.0413^{* * *} \\
(0.0055)\end{array}$ \\
\hline 6 & $\begin{array}{c}0.0173^{* * *} \\
(0.0028)\end{array}$ & $\begin{array}{c}0.0343^{* * *} \\
(0.0063)\end{array}$ & $\begin{array}{c}0.0125^{* * *} \\
(0.0038)\end{array}$ & $\begin{array}{c}0.0429 * * * \\
(0.0058)\end{array}$ \\
\hline 7 & $\begin{array}{c}0.0170 * * * \\
(0.0030)\end{array}$ & $\begin{array}{c}0.0348^{* * *} \\
(0.0067)\end{array}$ & $\begin{array}{c}0.0192^{* * *} \\
(0.0042)\end{array}$ & $\begin{array}{c}0.0435^{* * *} \\
(0.0060)\end{array}$ \\
\hline 8 & $\begin{array}{c}0.0180^{* * *} \\
(0.0032)\end{array}$ & $\begin{array}{c}0.0337^{* * *} \\
(0.0072)\end{array}$ & $\begin{array}{c}0.0207^{* * *} \\
(0.0045)\end{array}$ & $\begin{array}{c}0.0457^{* * *} * \\
(0.0063)\end{array}$ \\
\hline 9 & $\begin{array}{c}0.0185^{* * *} \\
(0.0034)\end{array}$ & $\begin{array}{c}0.0325^{* * *} \\
(0.0076)\end{array}$ & $\begin{array}{c}0.0234^{* * *} \\
(0.0049)\end{array}$ & $\begin{array}{c}0.0476 * * * \\
(0.0067)\end{array}$ \\
\hline 10 & $\begin{array}{c}0.0199 * * * \\
(0.0036)\end{array}$ & $\begin{array}{c}0.0311^{* * *} \\
(0.0080)\end{array}$ & $\begin{array}{c}0.0261^{* * *} \\
(0.0052)\end{array}$ & $\begin{array}{c}0.0489^{* * *} \\
(0.0070)\end{array}$ \\
\hline 11 & $\begin{array}{c}0.0209 * * * \\
(0.0039)\end{array}$ & $\begin{array}{c}0.0299 * * * \\
(0.0084)\end{array}$ & $\begin{array}{c}0.0270 * * * \\
(0.0055)\end{array}$ & $\begin{array}{c}0.0504^{* * *} \\
(0.0073)\end{array}$ \\
\hline 12 & $\begin{array}{c}0.0225^{* * *} \\
(0.0041)\end{array}$ & $\begin{array}{c}0.0293^{* * *} \\
(0.0088)\end{array}$ & $\begin{array}{c}0.0282^{* * *} \\
(0.0057)\end{array}$ & $\begin{array}{c}0.0510^{* * *} \\
(0.0076)\end{array}$ \\
\hline Observations & $5,874,402$ & $2,358,606$ & $2,257,531$ & $1,586,470$ \\
\hline
\end{tabular}

Note: Standard errors in parentheses; ${ }^{*} p<0.05,{ }^{* *} p<0.01,{ }^{* * *} p<0.001$; Samples are divided by within-firm tercile of earnings in 2005Q1 (for comparison group) or in the quarter prior to displacement (for displaced group). 
Table A.9: Cumulative Effect of Displacement from Manufacturing on Enrollment by Calendar Quarter of Layoff

\begin{tabular}{|c|c|c|c|c|}
\hline Quarter rel. to displacement & Jan-Mar & Apr-Jun & Jul-Sep & Oct-Dec \\
\hline \multirow[t]{2}{*}{-2} & -0.0016 & -0.0017 & -0.0011 & -0.0017 \\
\hline & $(0.0009)$ & $(0.0015)$ & $(0.0012)$ & $(0.0011)$ \\
\hline \multirow[t]{2}{*}{-1} & -0.0016 & -0.0022 & 0.0013 & -0.0013 \\
\hline & $(0.0014)$ & $(0.0019)$ & $(0.0019)$ & $(0.0015)$ \\
\hline \multirow[t]{2}{*}{0} & -0.0019 & -0.0025 & 0.0007 & 0.0015 \\
\hline & $(0.0017)$ & $(0.0023)$ & $(0.0022)$ & $(0.0021)$ \\
\hline \multirow[t]{2}{*}{1} & $0.0069 * *$ & 0.0016 & $0.0080 * *$ & $0.0055^{*}$ \\
\hline & $(0.0024)$ & $(0.0029)$ & $(0.0030)$ & $(0.0026)$ \\
\hline \multirow[t]{2}{*}{2} & $0.0112^{* * *}$ & $0.0111^{* *}$ & $0.0097^{* *}$ & $0.0139 * * *$ \\
\hline & $(0.0028)$ & $(0.0035)$ & $(0.0034)$ & $(0.0032)$ \\
\hline \multirow[t]{2}{*}{3} & $0.0141^{* * *}$ & $0.0112^{* *}$ & $0.0125^{* * *}$ & $0.0155^{* * *}$ \\
\hline & $(0.0032)$ & $(0.0038)$ & $(0.0038)$ & $(0.0036)$ \\
\hline \multirow[t]{2}{*}{4} & $0.0137^{* * *}$ & $0.0134^{* *}$ & $0.0127^{* *}$ & $0.0171^{* * *}$ \\
\hline & $(0.0035)$ & $(0.0042)$ & $(0.0041)$ & $(0.0040)$ \\
\hline \multirow[t]{2}{*}{5} & $0.0131^{* * *}$ & $0.0138 * *$ & $0.0131^{* *}$ & $0.0170 * * *$ \\
\hline & $(0.0038)$ & $(0.0045)$ & $(0.0045)$ & $(0.0043)$ \\
\hline \multirow[t]{2}{*}{6} & $0.0124^{* *}$ & $0.0137^{* *}$ & $0.0123^{*}$ & $0.0177^{* * *}$ \\
\hline & $(0.0041)$ & $(0.0050)$ & $(0.0049)$ & $(0.0046)$ \\
\hline \multirow[t]{2}{*}{7} & $0.0152^{* * *}$ & $0.0139 * *$ & $0.0108^{*}$ & $0.0179^{* * *}$ \\
\hline & $(0.0045)$ & $(0.0054)$ & $(0.0053)$ & $(0.0050)$ \\
\hline \multirow[t]{2}{*}{8} & $0.0147^{* *}$ & $0.0133^{*}$ & 0.0101 & $0.0188^{* * *}$ \\
\hline & $(0.0048)$ & $(0.0057)$ & $(0.0056)$ & $(0.0054)$ \\
\hline \multirow[t]{2}{*}{9} & $0.0150 * *$ & $0.0131^{*}$ & 0.0100 & $0.0185^{* *}$ \\
\hline & $(0.0051)$ & $(0.0061)$ & $(0.0060)$ & $(0.0057)$ \\
\hline \multirow[t]{2}{*}{10} & $0.0147^{* *}$ & 0.0117 & 0.0094 & $0.0210^{* * *}$ \\
\hline & $(0.0054)$ & $(0.0065)$ & $(0.0064)$ & $(0.0061)$ \\
\hline \multirow[t]{2}{*}{11} & $0.0135^{*}$ & 0.0106 & 0.0098 & $0.0217^{* * *}$ \\
\hline & $(0.0057)$ & $(0.0068)$ & $(0.0068)$ & $(0.0064)$ \\
\hline \multirow[t]{2}{*}{12} & $0.0137^{*}$ & 0.0089 & 0.0084 & $0.0234^{* * *}$ \\
\hline & $(0.0060)$ & $(0.0072)$ & $(0.0071)$ & $(0.0068)$ \\
\hline Observations & $10,327,405$ & $10,301,977$ & $10,302,310$ & $10,308,711$ \\
\hline
\end{tabular}

Note: Standard errors in parentheses; ${ }^{*} p<0.05,{ }^{* *} p<0.01,{ }^{* * *} p<0.001$; Samples are divided by within-firm tercile of earnings in 2005Q1 (for comparison group) or in the quarter prior to displacement (for displaced group). 
Table A.10: Cumulative Effect of Displacement from Manufacturing on Enrollment by Firm Size

\begin{tabular}{|c|c|c|}
\hline Quarter rel. to displacement & $<500$ employees & $\geq 500$ employees \\
\hline-2 & $\begin{array}{c}0.0006 \\
(0.0007)\end{array}$ & $\begin{array}{l}-0.0005 \\
(0.0007)\end{array}$ \\
\hline-1 & $\begin{array}{l}0.0022^{*} \\
(0.0010)\end{array}$ & $\begin{array}{c}0.0002 \\
(0.0010)\end{array}$ \\
\hline 0 & $\begin{array}{l}0.0028^{*} \\
(0.0012)\end{array}$ & $\begin{array}{c}0.0019 \\
(0.0013)\end{array}$ \\
\hline 1 & $\begin{array}{c}0.0079 * * * \\
(0.0016)\end{array}$ & $\begin{array}{c}0.0107^{* * *} \\
(0.0018)\end{array}$ \\
\hline 2 & $\begin{array}{c}0.0130^{* * *} \\
(0.0020)\end{array}$ & $\begin{array}{c}0.0194^{* * *} \\
(0.0022)\end{array}$ \\
\hline 3 & $\begin{array}{c}0.0169 * * * \\
(0.0023)\end{array}$ & $\begin{array}{c}0.0212^{* * *} \\
(0.0024)\end{array}$ \\
\hline 4 & $\begin{array}{c}0.0180^{* * *} \\
(0.0025)\end{array}$ & $\begin{array}{c}0.0232^{* * *} * \\
(0.0026)\end{array}$ \\
\hline 5 & $\begin{array}{c}0.0196^{* * *} \\
(0.0027)\end{array}$ & $\begin{array}{c}0.0233^{* * *} \\
(0.0028)\end{array}$ \\
\hline 6 & $\begin{array}{c}0.0206^{* * *} \\
(0.0029)\end{array}$ & $\begin{array}{c}0.0231^{* * *} \\
(0.0030)\end{array}$ \\
\hline 7 & $\begin{array}{c}0.0209^{* * *} * \\
(0.0031)\end{array}$ & $\begin{array}{c}0.0251^{* * *} \\
(0.0033)\end{array}$ \\
\hline 8 & $\begin{array}{c}0.0217^{* * *} \\
(0.0033)\end{array}$ & $\begin{array}{c}0.0255^{* * *} * \\
(0.0035)\end{array}$ \\
\hline 9 & $\begin{array}{c}0.0220^{* * * *} \\
(0.0035)\end{array}$ & $\begin{array}{c}0.0266^{* * *} \\
(0.0037)\end{array}$ \\
\hline 10 & $\begin{array}{c}0.0230^{* * *} \\
(0.0037)\end{array}$ & $\begin{array}{c}0.0272^{* * *} \\
(0.0039)\end{array}$ \\
\hline 11 & $\begin{array}{c}0.0236^{* * *} \\
(0.0039)\end{array}$ & $\begin{array}{c}0.0274^{* * *} \\
(0.0041)\end{array}$ \\
\hline 12 & $\begin{array}{c}0.0234^{* * *} \\
(0.0041)\end{array}$ & $\begin{array}{c}0.0286^{* * *} \\
(0.0043)\end{array}$ \\
\hline Observations & $4,595,077$ & $6,810,410$ \\
\hline
\end{tabular}

Note: Standard errors in parentheses; ${ }^{*} p<0.05,{ }^{* *} p<0.01,{ }^{* * *} p<0.001$; Samples are divided by within-firm tercile of earnings in 2005Q1 (for comparison group) or in the quarter prior to displacement (for displaced group). 
Table A.11: Cumulative Effect of Displacement from Manufacturing on Enrollment by Firm Size

\begin{tabular}{|c|c|c|}
\hline Quarter rel. to displacement & $<1,000$ employees & $\geq 1,000$ employees \\
\hline-2 & $\begin{array}{c}0.0005 \\
(0.0006)\end{array}$ & $\begin{array}{l}-0.0005 \\
(0.0008)\end{array}$ \\
\hline-1 & $\begin{array}{l}0.0019^{*} \\
(0.0009)\end{array}$ & $\begin{array}{c}0.0001 \\
(0.0011)\end{array}$ \\
\hline 0 & $\begin{array}{c}0.0027^{*} \\
(0.0011)\end{array}$ & $\begin{array}{c}0.0020 \\
(0.0015)\end{array}$ \\
\hline 1 & $\begin{array}{c}0.0092 * * * \\
(0.0015)\end{array}$ & $\begin{array}{c}0.0099 * * * \\
(0.0020)\end{array}$ \\
\hline 2 & $\begin{array}{c}0.0163^{* * *} \\
(0.0019)\end{array}$ & $\begin{array}{c}0.0169^{* * *} \\
(0.0024)\end{array}$ \\
\hline 3 & $\begin{array}{c}0.0198^{* * *} * \\
(0.0021)\end{array}$ & $\begin{array}{c}0.0190^{* * *} \\
(0.0027)\end{array}$ \\
\hline 4 & $\begin{array}{c}0.0215^{* * *} \\
(0.0023)\end{array}$ & $\begin{array}{c}0.0203^{* * *} \\
(0.0029)\end{array}$ \\
\hline 5 & $\begin{array}{c}0.0234^{* * * *} \\
(0.0025)\end{array}$ & $\begin{array}{c}0.0199^{* * * *} \\
(0.0031)\end{array}$ \\
\hline 6 & $\begin{array}{c}0.0243^{* * *} \\
(0.0027)\end{array}$ & $\begin{array}{c}0.0197^{* * *} \\
(0.0034)\end{array}$ \\
\hline 7 & $\begin{array}{c}0.0246^{* * *} \\
(0.0028)\end{array}$ & $\begin{array}{c}0.0220^{* * *} \\
(0.0036)\end{array}$ \\
\hline 8 & $\begin{array}{c}0.0251^{* * *} \\
(0.0030)\end{array}$ & $\begin{array}{c}0.0227^{* * *} \\
(0.0039)\end{array}$ \\
\hline 9 & $\begin{array}{c}0.0253^{* * *} \\
(0.0032)\end{array}$ & $\begin{array}{c}0.0240^{* * * *} \\
(0.0041)\end{array}$ \\
\hline 10 & $\begin{array}{c}0.0261^{* * *} \\
(0.0034)\end{array}$ & $\begin{array}{c}0.0247^{* * *} \\
(0.0044)\end{array}$ \\
\hline 11 & $\begin{array}{c}0.0266^{* * * *} \\
(0.0035)\end{array}$ & $\begin{array}{c}0.0250^{* * *} \\
(0.0046)\end{array}$ \\
\hline 12 & $\begin{array}{c}0.0264^{* * *} \\
(0.0037)\end{array}$ & $\begin{array}{c}0.0265^{* * *} \\
(0.0049)\end{array}$ \\
\hline Observations & $6,649,260$ & $4,756,227$ \\
\hline
\end{tabular}

Note: Standard errors in parentheses; ${ }^{*} p<0.05,{ }^{* *} p<0.01,{ }^{* * *} p<0.001$; Samples are divided by within-firm tercile of earnings in 2005Q1 (for comparison group) or in the quarter prior to displacement (for displaced group). 
Table A.12: Cumulative Effect of Displacement from Manufacturing Firm Shutdown on Enrollment

\begin{tabular}{|c|c|c|}
\hline Quarter rel. to displacement & $\begin{array}{c}\text { All Displaced } \\
\text { from Manufacturing }\end{array}$ & $\begin{array}{c}\text { Displaced in } \\
\text { Manufacturing Shutdown }\end{array}$ \\
\hline-2 & $\begin{array}{c}0.0000 \\
(0.0005)\end{array}$ & $\begin{array}{l}-0.0004 \\
(0.0011)\end{array}$ \\
\hline-1 & $\begin{array}{c}0.0011 \\
(0.0007)\end{array}$ & $\begin{array}{l}-0.0000 \\
(0.0015)\end{array}$ \\
\hline 0 & $\begin{array}{c}0.0024^{* *} \\
(0.0009)\end{array}$ & $\begin{array}{c}0.0013 \\
(0.0019)\end{array}$ \\
\hline 1 & $\begin{array}{c}0.0096^{* * *} \\
(0.0012)\end{array}$ & $\begin{array}{c}0.0072^{* *} \\
(0.0025)\end{array}$ \\
\hline 2 & $\begin{array}{c}0.0167^{* * *} \\
(0.0015)\end{array}$ & $\begin{array}{c}0.0184^{* * *} \\
(0.0032)\end{array}$ \\
\hline 3 & $\begin{array}{c}0.0195^{* * *} \\
(0.0017)\end{array}$ & $\begin{array}{c}0.0197^{* * *} \\
(0.0034)\end{array}$ \\
\hline 4 & $\begin{array}{c}0.0211^{* * * *} \\
(0.0018)\end{array}$ & $\begin{array}{c}0.0199 * * * \\
(0.0037)\end{array}$ \\
\hline 5 & $\begin{array}{c}0.0219^{* * *} \\
(0.0020)\end{array}$ & $\begin{array}{c}0.0199 * * * \\
(0.0040)\end{array}$ \\
\hline 6 & $\begin{array}{c}0.0223^{* * *} \\
(0.0021)\end{array}$ & $\begin{array}{c}0.0202^{* * *} \\
(0.0043)\end{array}$ \\
\hline 7 & $\begin{array}{c}0.0236^{* * *} \\
(0.0023)\end{array}$ & $\begin{array}{c}0.0209^{* * *} \\
(0.0046)\end{array}$ \\
\hline 8 & $\begin{array}{c}0.0243^{* * * *} \\
(0.0024)\end{array}$ & $\begin{array}{c}0.0218^{* * *} \\
(0.0049)\end{array}$ \\
\hline 9 & $\begin{array}{c}0.0250^{* * *} \\
(0.0026)\end{array}$ & $\begin{array}{c}0.0216^{* * *} \\
(0.0052)\end{array}$ \\
\hline 10 & $\begin{array}{c}0.0259^{* * *} \\
(0.0027)\end{array}$ & $\begin{array}{c}0.0227^{* * *} \\
(0.0055)\end{array}$ \\
\hline 11 & $\begin{array}{c}0.0264^{* * *} \\
(0.0029)\end{array}$ & $\begin{array}{c}0.0230^{* * *} \\
(0.0058)\end{array}$ \\
\hline 12 & $\begin{array}{c}0.0270^{* * *} \\
(0.0030)\end{array}$ & $\begin{array}{c}0.0249 * * * \\
(0.0061)\end{array}$ \\
\hline Observations & $11,405,487$ & $10,312,303$ \\
\hline
\end{tabular}

Note: Standard errors in parentheses; ${ }^{*} p<0.05,{ }^{* *} p<0.01,{ }^{* * *} p<0.001$; Samples are divided by within-firm tercile of earnings in 2005Q1 (for comparison group) or in the quarter prior to displacement (for displaced group). 
Figure A.1: Cumulative Effect of Displacement from Manufacturing on Enrollment by Earnings Percentile

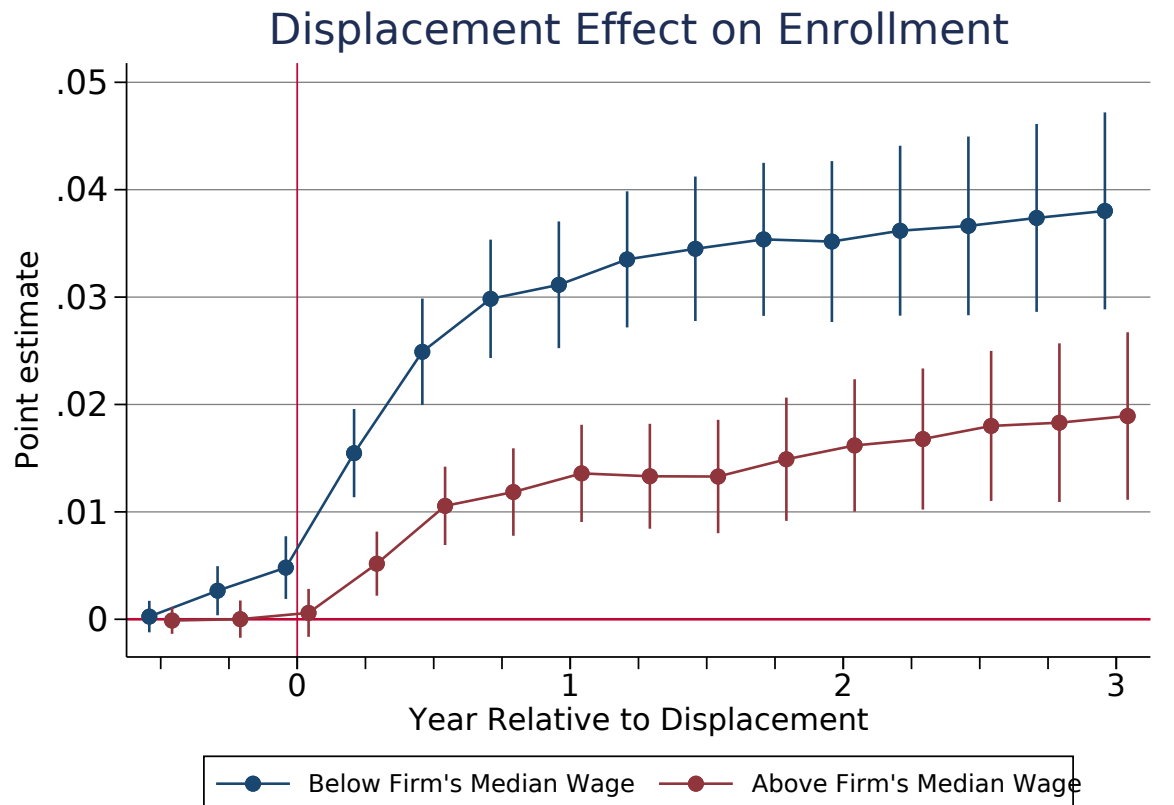

(a) Above/Below Median

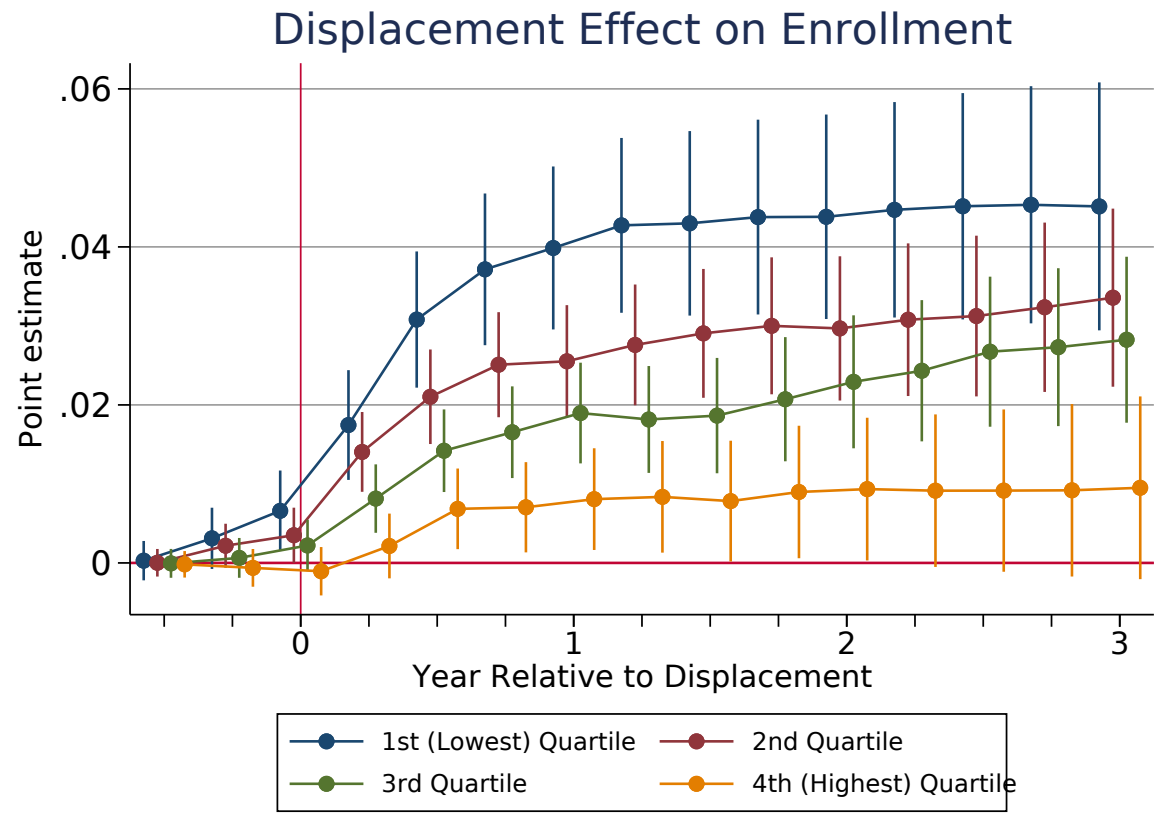

(b) Quartile

Note: Figures plot the estimated $\hat{\delta}_{k}$ 's from equation (1) split by manufacturing workers' percentile of earnings within the firm. Panel (a) splits workers by earnings relative to the median, and panel (b) split workers by quartiles. Whiskers denote 95-percent confidence intervals based on standard errors clustered by worker. Displaced sample is laid off between 2002q1 and 2009q4. Point estimates and standard errors are listed in Appendix Tables A.5 and A.6. 
Figure A.2: Cumulative Effect of Displacement from Manufacturing on Enrollment by Quarter of Layoff

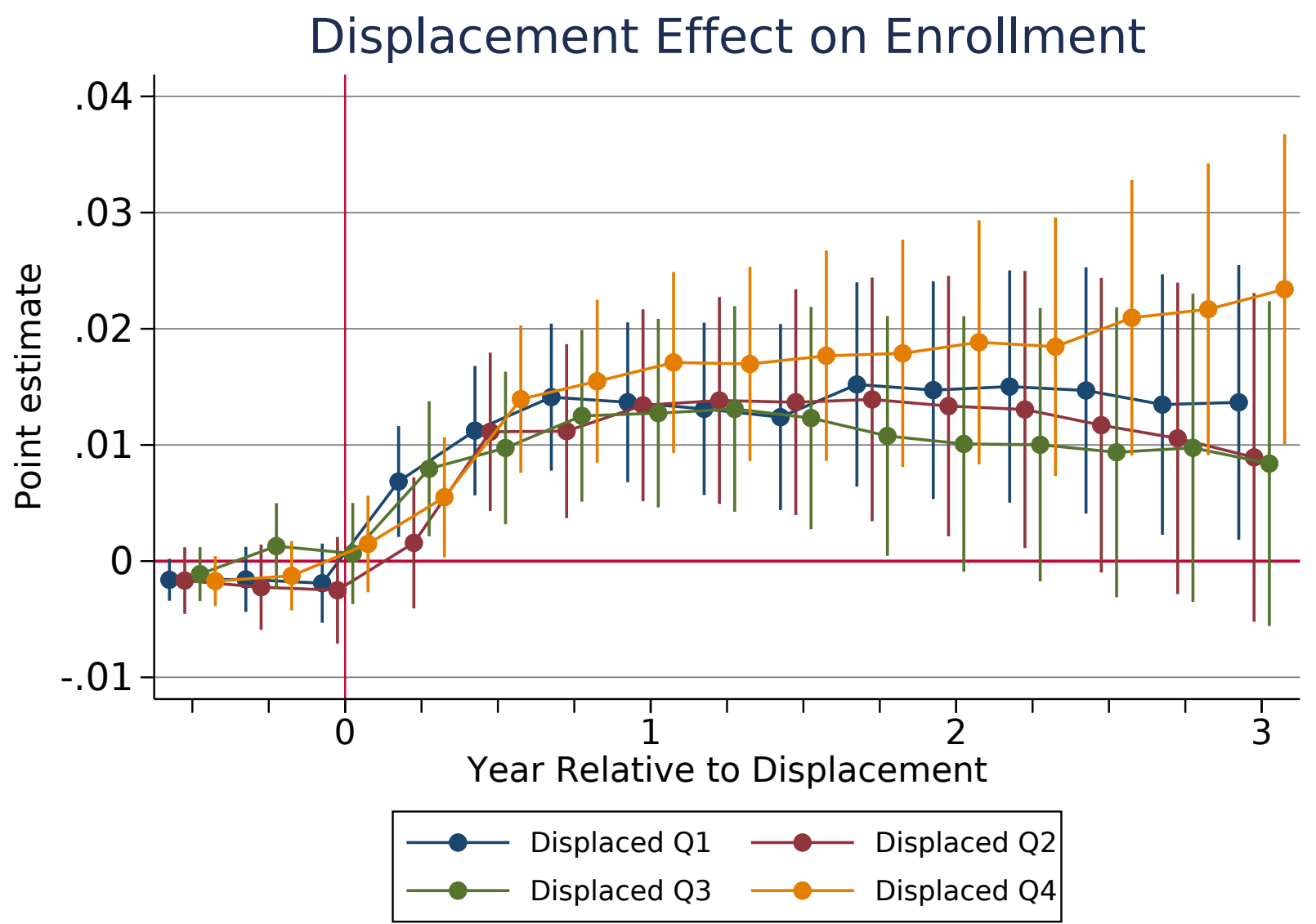

Note: Figure plots the estimated $\hat{\delta}_{k}$ 's from equation (1) for the sample employed by or displaced from manufacturing firms split by calendar quarter of layoff. $30 \%$ of the displaced sample was laid off in the first quarter (Jan-Mar), $22 \%$ in the second quarter (Apr-Jun), 23\% in the third quarter (Jul-Sep), and 25\% in the fourth quarter (Oct-Dec). Whiskers denote 95-percent confidence intervals based on standard errors clustered by worker. Displaced sample is laid off between 2002q1 and 2009q4. Point estimates and standard errors are listed in Appendix Table A.9. 
Figure A.3: Cumulative Effect of Displacement from Manufacturing on Enrollment by Firm Size

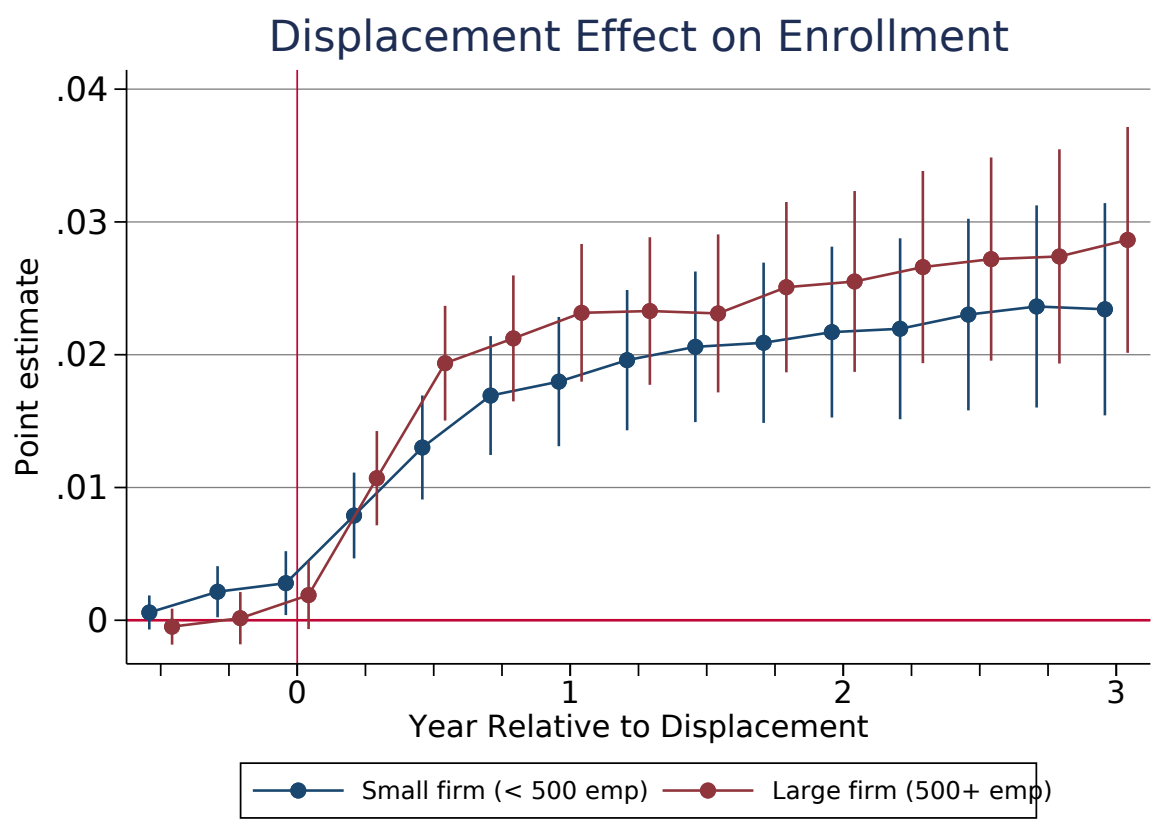

(a) Firm Split: $\geq 500$ employees

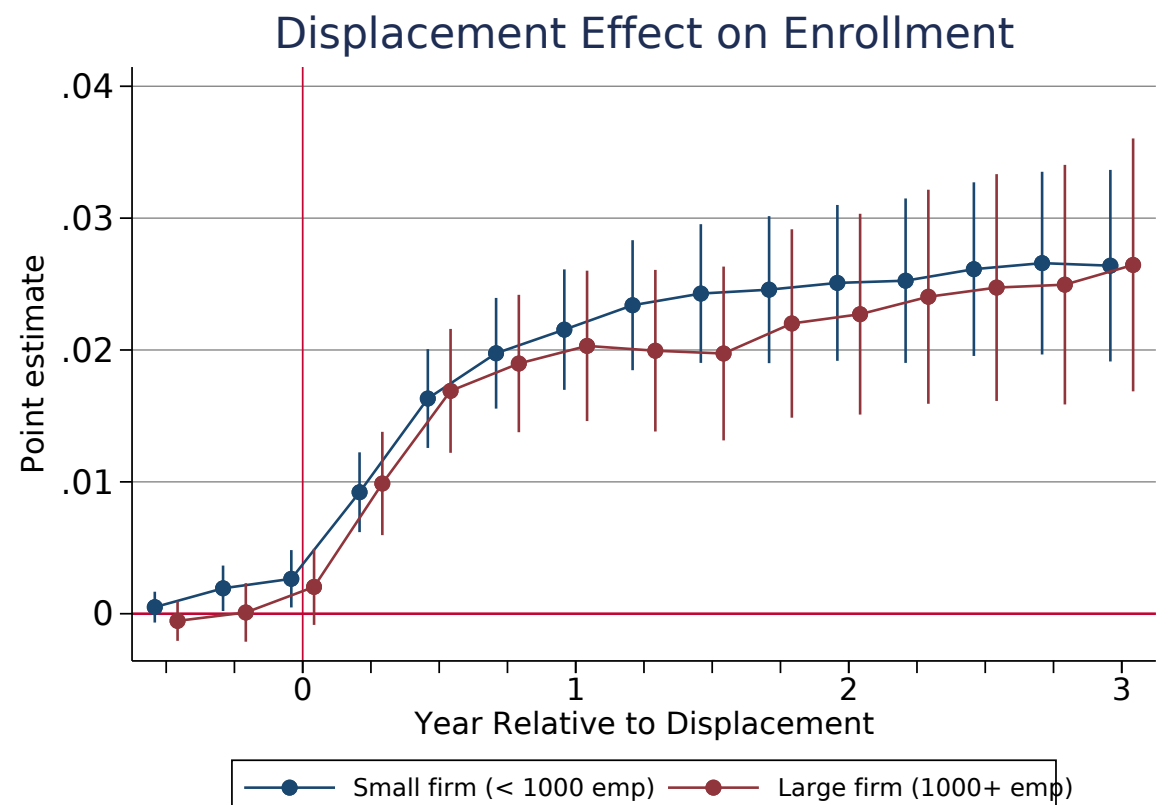

(b) Firm Split: $\geq 1,000$ employees

Note: Figures plot the estimated $\hat{\delta}_{k}$ 's from equation (1) split by the size of firm from which manufacturing workers were laid off. In panel (a), a large firm is an employer with more than 500 employees at its maximum size between 2002 and 2009. In panel (b), the cutoff is 1,000 employees. $60 \%(42 \%)$ of displaced manufacturing workers in our sample were laid off from a firm with more than $500(1,000)$ workers. Whiskers denote 95-percent confidence intervals based on standard errors clustered by worker. Displaced sample is laid off between 2002q1 and 2009q4. Point estimates and standard errors are listed in Appendix Tables A.10 and A.11. 
Figure A.4: Cumulative Effect of Displacement in Manufacturing Firm Shutdown on Enrollment

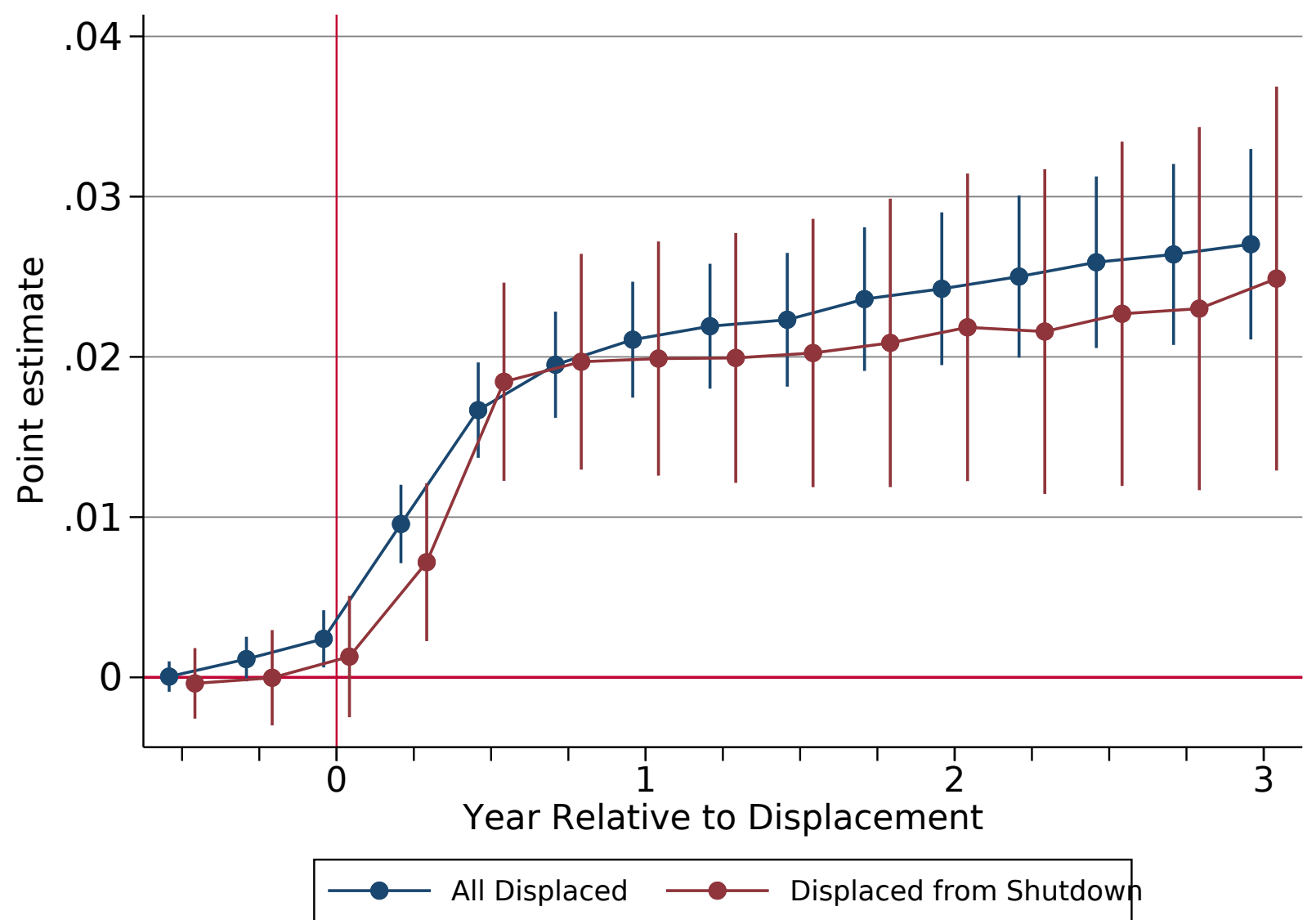

Note: Figure plots the estimated $\hat{\delta}_{k}$ 's from equation (1) for the overall displaced sample (blue) and workers who were displaced in a firm shutdown (red), both compared to a non-displaced comparison sample. $26 \%$ of displaced manufacturing employees were laid off in a shutdown, defined as separating within 6 quarters of a firm's closing. Whiskers denote 95-percent confidence intervals based on standard errors clustered by worker. Displaced sample is laid off between 2002q1 and 2009q4. Point estimates and standard errors are listed in Appendix Table A.12. 
Figure A.5: Cumulative Effect of Displacement from Manufacturing on Enrollment by County-Level Community College Proximity

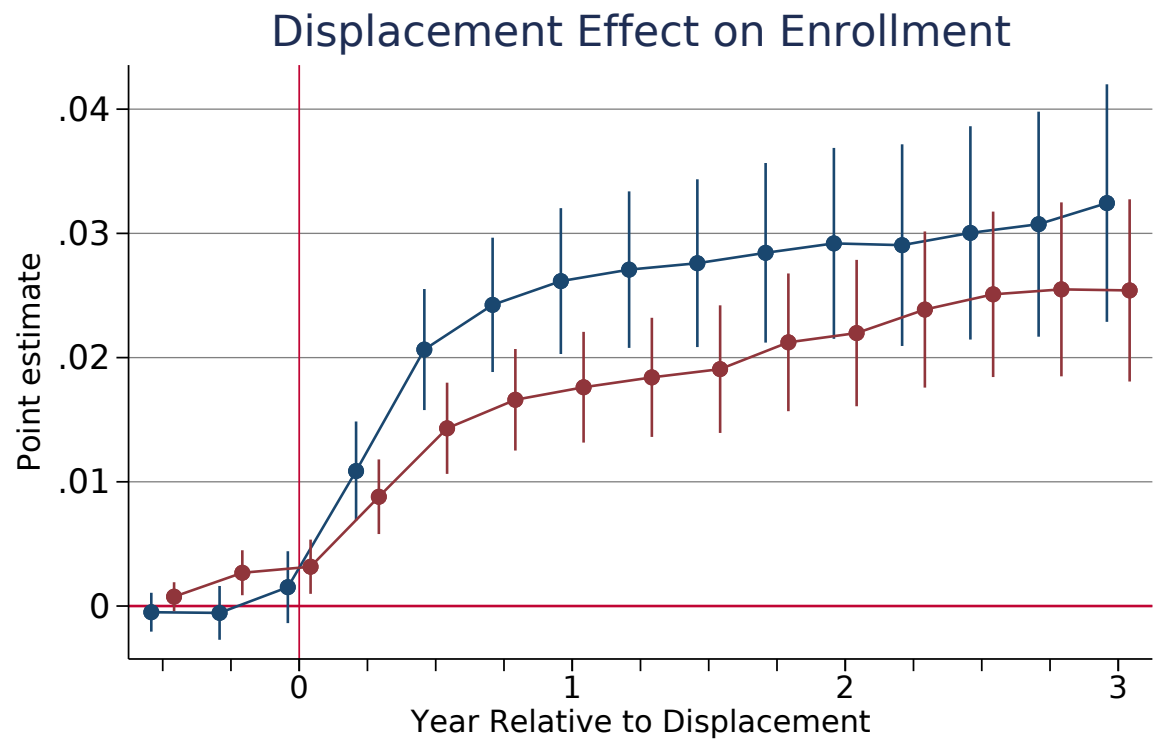

$\longrightarrow$ Community College County $\longrightarrow$ Non-Community College County

(a) County with and without Community College

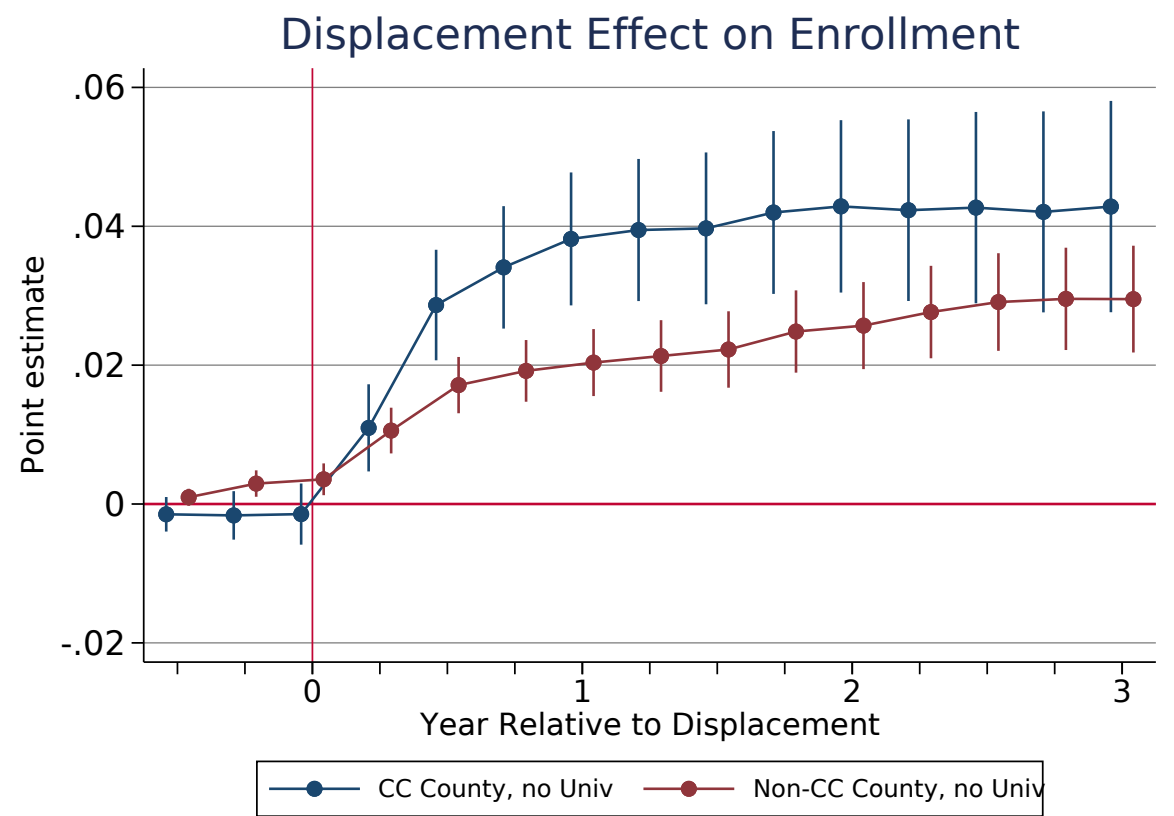

(b) County with or without Community College (no 4-year University)

Note: Figures plot the estimated $\hat{\delta}_{k}$ 's from equation (1) split by whether a comparison or displaced manufacturing worker is employed in a county with a public community college. In panel (a), we include displaced and comparison from all 88 Ohio counties. In panel (b), we restrict to those workers in counties without a 4-year university ("main universities" specified in Table B.3). Whiskers denote 95-percent confidence intervals based on standard errors clustered by worker. Displaced sample is laid off between 2002q1 and 2009q4. 
Figure A.6: Cumulative Effect of Displacement on Enrollment, no Worker-Specific Time-Trends

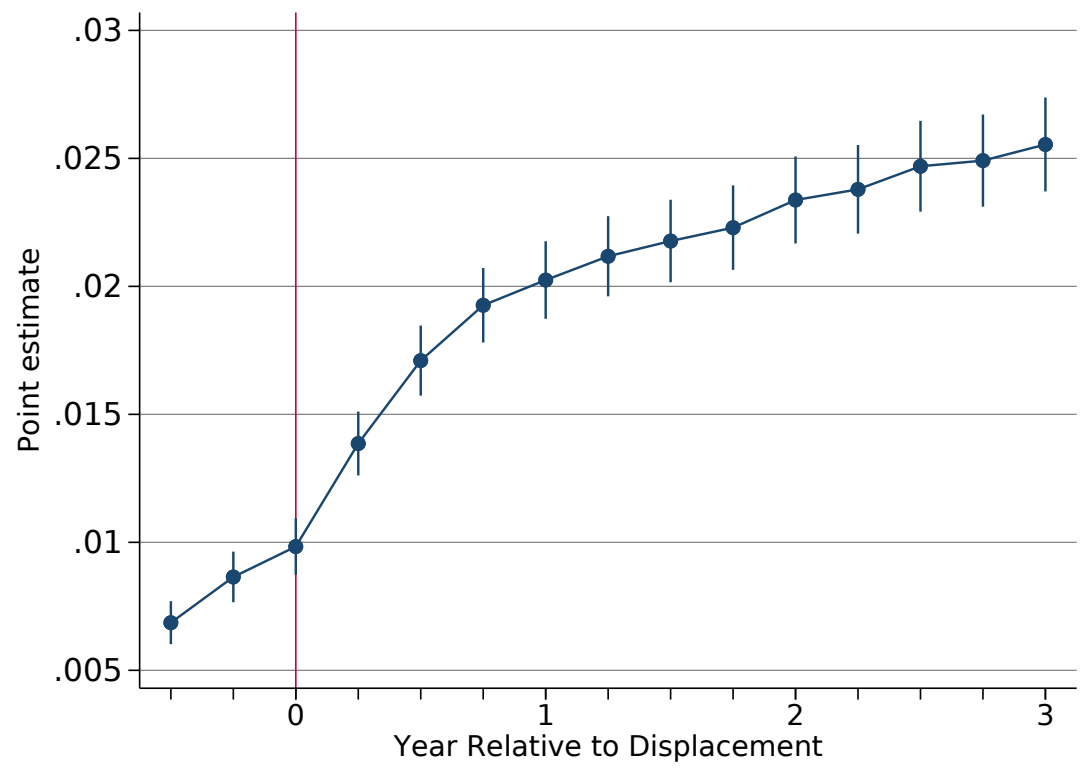

Note: Figure plots the estimated $\hat{\delta}_{k}$ 's from equation (2), which is a modified version of equation (1) which omits worker-specific time trends, for the overall displaced sample and comparison sample. Whiskers denote 95-percent confidence intervals based on standard errors clustered by worker. Displaced sample is laid off between 2002q1 and $2009 \mathrm{q} 4$.

Figure A.7: Effect of Displacement on Enrollment as Measured by Cumulative Credits

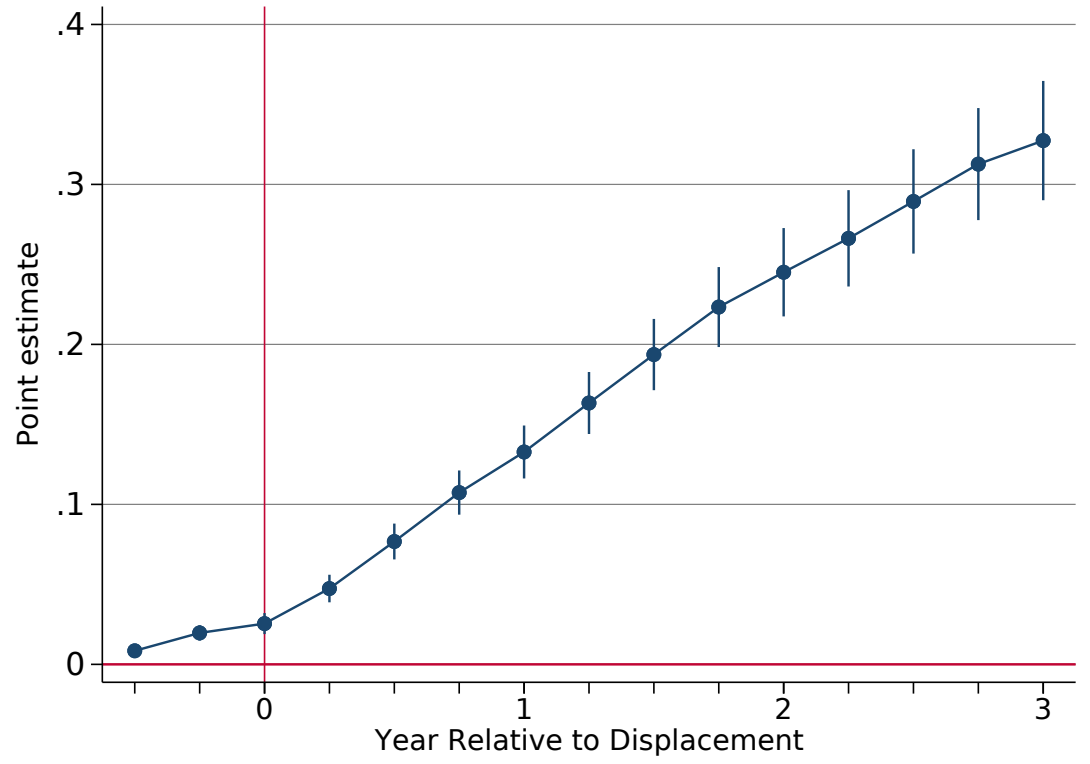

Note: Figure plots the estimated $\hat{\delta}_{k}$ 's from equation (3), which uses a measure of cumulative college credits earned as a dependent variable. Whiskers denote 95-percent confidence intervals based on standard errors clustered by worker. Displaced sample is laid off between 2002q1 and 2009q4. 
Figure A.8: Effect of Displacement on Point-in-Time Enrollment

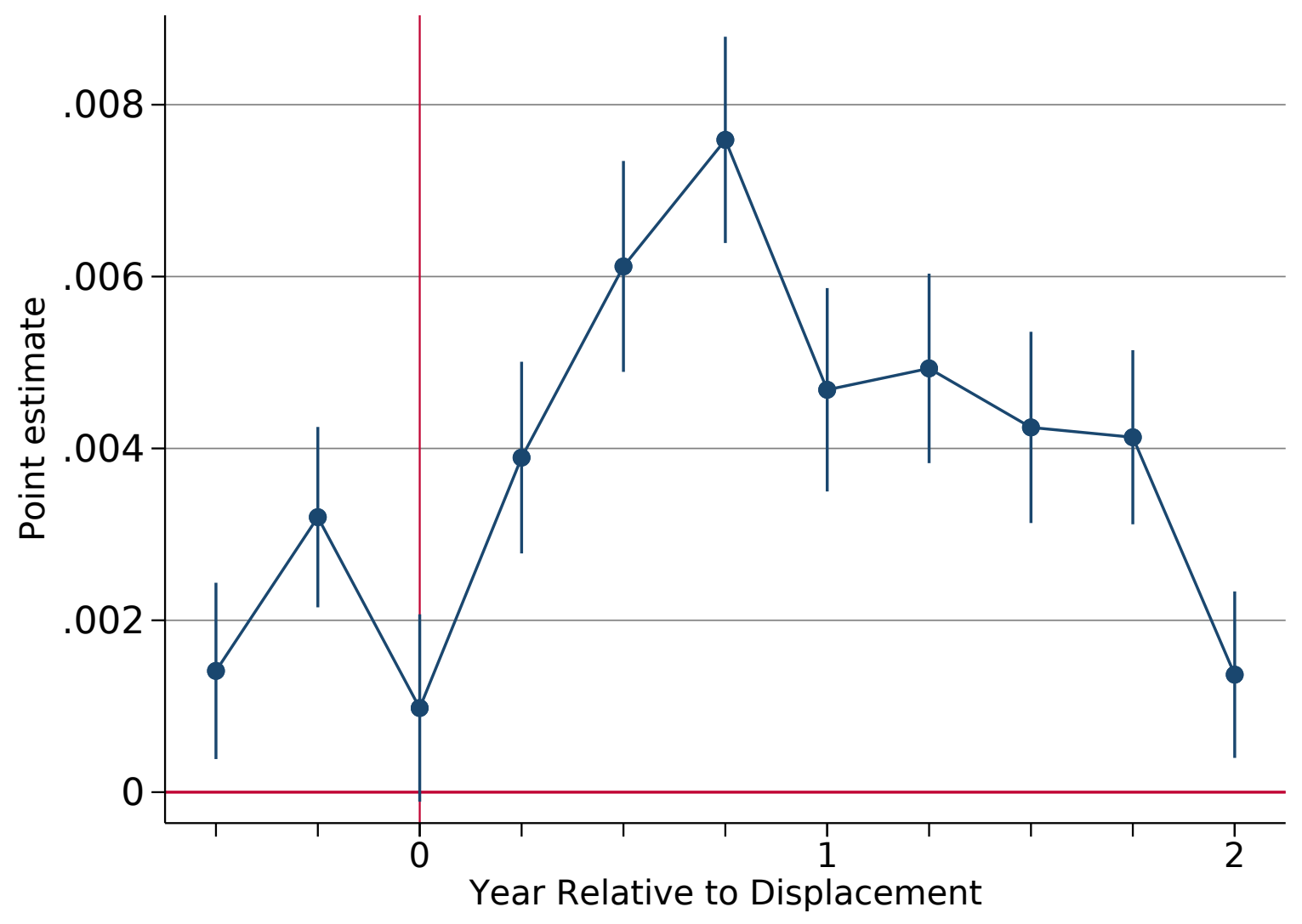

Note: Figure plots the estimated $\hat{\delta}_{k}$ 's from equation (4), a specification with a point-in-time enrollment measure as the dependent variable. Whiskers denote 95 -percent confidence intervals based on standard errors clustered by worker. Displaced sample is laid off between 2002q1 and 2009q4. 


\section{B Higher Education in Ohio}

Enrollment records for this study come from the Ohio Higher Education Information (HEI) system and cover each of Ohio's public higher education institutions. Table B.1 lists each commuting zone, the number of counties it contains, and the number of 2-year public, 4-year public, and for-profit higher education institutions. The community colleges and universities are listed, along with their locations, in Tables B.2 and B.3.

Table B.1: Ohio Higher Education Availability by Commuting Zone

\begin{tabular}{|c|c|c|c|c|c|}
\hline Commuting Zone Name & $\begin{array}{c}\text { \# Counties } \\
\text { in CZ }\end{array}$ & $\begin{array}{c}\text { Public } \\
\text { Institutions }\end{array}$ & $\begin{array}{c}\text { 2-Year } \\
\text { Public Inst. }\end{array}$ & $\begin{array}{c}\text { 4-Year } \\
\text { Public Inst. }\end{array}$ & $\begin{array}{c}\text { For-Profit } \\
\text { Colleges }\end{array}$ \\
\hline \multicolumn{6}{|c|}{ High-Public, High-For-Profit } \\
\hline Cincinnati & 6 & 9 & 5 & 4 & 23 \\
\hline Cleveland & 7 & 11 & 7 & 4 & 51 \\
\hline Columbus & 9 & 10 & 3 & 7 & 22 \\
\hline \multicolumn{6}{|c|}{ High-Public, Low-For-Profit } \\
\hline Dayton & 9 & 7 & 3 & 4 & 14 \\
\hline Portsmouth & 5 & 8 & 2 & 6 & 4 \\
\hline Toledo & 5 & 7 & 5 & 2 & 7 \\
\hline \multicolumn{6}{|c|}{ Low-Public, High-For-Profit } \\
\hline Canton & 7 & 5 & 1 & 4 & 5 \\
\hline Lorain & 3 & 2 & 1 & 1 & 3 \\
\hline Youngstown & 3 & 4 & 0 & 4 & 14 \\
\hline \multicolumn{6}{|c|}{ Low-Public, Low-For-Profit } \\
\hline Athens & 3 & 3 & 1 & 2 & 1 \\
\hline Defiance & 3 & 1 & 1 & 0 & 0 \\
\hline Findlay & 5 & 5 & 4 & 1 & 2 \\
\hline Lima & 5 & 3 & 0 & 3 & 1 \\
\hline Mansfield & 5 & 4 & 2 & 2 & 1 \\
\hline Washington & 3 & 1 & 1 & 0 & 0 \\
\hline Wheeling, WV & 2 & 2 & 1 & 1 & 0 \\
\hline Zanesville & 5 & 3 & 2 & 1 & 1 \\
\hline
\end{tabular}

Note: Comparison and displaced workers employed in the Parkersburg, WV and Huntingon, WV commuting zones are excluded from the geographic analysis because these CZs only include one Ohio county. 
Table B.2: Ohio Community Colleges

\begin{tabular}{|c|c|c|c|c|}
\hline \multirow[b]{2}{*}{ School } & \multirow[b]{2}{*}{ City } & \multirow[b]{2}{*}{ County } & \multicolumn{2}{|c|}{ University in County } \\
\hline & & & Main & Branch \\
\hline COTC-Coshocton Campus & Coshocton & Coshocton & & \\
\hline COTC-Knox Campus & Mount Vernon & Knox & & \\
\hline COTC-Pataskala Campus & Pataskala & Franklin & $\checkmark$ & \\
\hline CSCC-Delaware Campus & Delaware & Delaware & & \\
\hline Cincinnati State Technical \& CC & Cincinnati & Hamilton & $\checkmark$ & $\checkmark$ \\
\hline Clark State-Greene Center & Beakercreek & Greene & $\checkmark$ & \\
\hline Clark State CC & Springfield & Clark & & \\
\hline Columbus State CC & Columbus & Franklin & $\checkmark$ & \\
\hline Cuyahoga CC & Cleveland & Cuyahoga & $\checkmark$ & \\
\hline Edison-Darke County CC & Greenville & Darke & & \\
\hline Edison CC & Piqua & Miami & & \\
\hline Hocking-Logan Campus & Logan & Hocking & & \\
\hline Hocking-Perry Campus & New Lexington & Perry & & \\
\hline Hocking College & Nelsonville & Athens & $\checkmark$ & \\
\hline Lakeland CC & Kirtland & Lake & & \\
\hline Lorain County CC & Elyria & Lorain & & \\
\hline Northwest State CC & Archbold & Fulton & & \\
\hline Owens -Findlay campus & Findlay & Hancock & & \\
\hline Owens CC & Perrysburg & Wood & $\checkmark$ & \\
\hline SSCC-Fayette Campus & Washington Court House & Fayette & & \\
\hline SSCC-North Campus & Wilmington & Clinton & & \\
\hline SSCC-South Campus & Sardinia & Brown & & \\
\hline Sinclair CC & Dayton & Montgomery & & \\
\hline Southern State CC & Hillsboro & Highland & & \\
\hline Terra State CC & Fremont & Sandusky & & \\
\hline Washington State CC & Marietta & Washington & & \\
\hline
\end{tabular}

Note $:$ COTC $=$ Central Ohio Technical College; SSCC $=$ Southern State Community College 
Table B.3: Ohio Four-Year Colleges and University

\begin{tabular}{|c|c|c|c|}
\hline School & City & County & $\begin{array}{l}\text { Comm. Coll. } \\
\text { in County }\end{array}$ \\
\hline \multicolumn{4}{|l|}{ Main Universities } \\
\hline Bowling Green State University & Bowling Green & Wood & $\checkmark$ \\
\hline Central State University & Wilberforce & Greene & $\checkmark$ \\
\hline Cleveland State University & Cleveland & Cuyahoga & $\checkmark$ \\
\hline Kent State University & Kent & Portage & \\
\hline Miami University & Oxford & Butler & \\
\hline Ohio University & Athens & Athens & $\checkmark$ \\
\hline Shawnee State University & Portsmouth & Scioto & \\
\hline The Ohio State University & Columbus & Franklin & $\checkmark$ \\
\hline University of Akron & Akron & Summit & \\
\hline University of Cincinnati & Cincinnati & Hamilton & $\checkmark$ \\
\hline University of Toledo & Toledo & Lucas & \\
\hline Wright State University & Dayton & Greene & $\checkmark$ \\
\hline Youngstown State University & Youngstown & Mahoning & \\
\hline \multicolumn{4}{|l|}{ Branch Universities } \\
\hline Bowling Green State University & Huron & Erie & \\
\hline Kent State University & Ashtabula & Ashtabula & \\
\hline Kent State University & East Liverpool & Columbiana & \\
\hline Kent State University & New Philadelphia & Tuscarawas & \\
\hline Kent State University & Canton & Stark & \\
\hline Kent State University & Burton & Geauga & \\
\hline Kent State University & Salem & Columbiana & \\
\hline Kent State University & Warren & Trumbull & \\
\hline Miami University & Hamilton & Butler & \\
\hline Miami University & Middletown & Butler & \\
\hline Ohio University & Chillicothe & Ross & \\
\hline Ohio University & Zanesville & Muskingum & \\
\hline Ohio University & Lancaster & Fairfield & \\
\hline Ohio University & Ironton & Pike & \\
\hline Ohio University & Saint Clairsville & Belmont & \\
\hline The Ohio State University & Mansfield & Richland & \\
\hline The Ohio State University & Newark & Licking & \\
\hline The Ohio State University & Wooster & Wayne & \\
\hline The Ohio State University & Marion & Marion & \\
\hline The Ohio State University & Lima & Allen & \\
\hline University of Akron & Orrville & Wayne & \\
\hline University of Cincinnati & Batavia & Clermont & \\
\hline University of Cincinnati & Blue Ash & Hamilton & $\checkmark$ \\
\hline Wright State University & Celina & Mercer & \\
\hline
\end{tabular}


Figure B.1: Map of Ohio Public Institutions of Higher Education

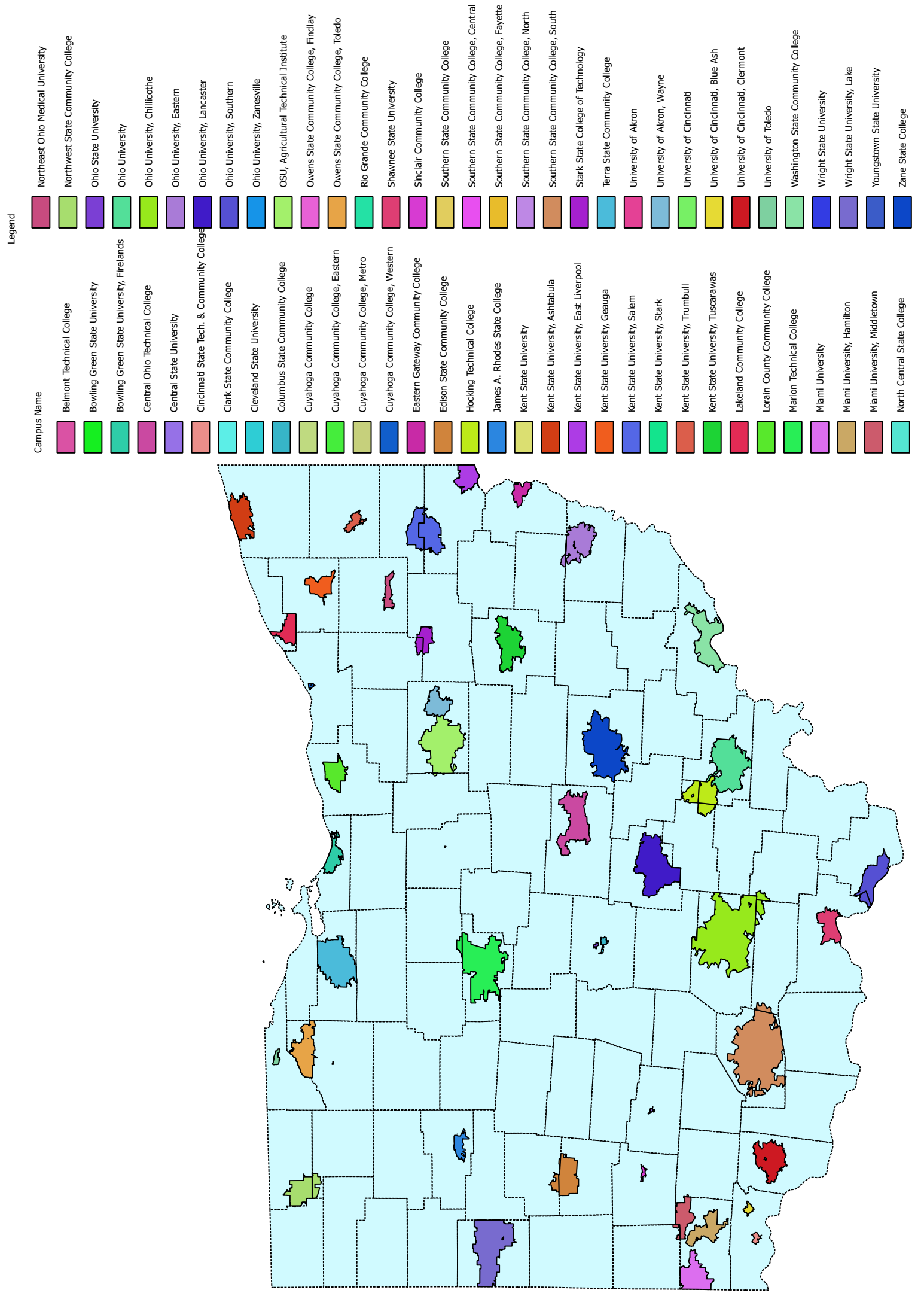




\section{Comparison to Displaced Worker Survey}

Our Ohio administrative data includes limitations that are typical of state administrative UI databases, such as inability to distinguish between individuals who leave Ohio, exit the labor force, or begin working for non UI-covered employers in the state. Moreover, although our education data includes a rich set of demographic variables, we lack them for workers in the UI sample. Thus, we only observe characteristics like race, age, and gender for the subset of displaced workers who were enrolled in the Ohio public higher education system at some point during the selected timeframe.

To supplement our Ohio sample's descriptive statistics, we analyze data from the Displaced Workers Surveys (DWS), administered every two years from as a supplement to the Current Population Survey (CPS). The DWS has been utilized in displaced worker studies for several decades (Neal, 1995; Hipple, 1999; Schmieder and Von Wachter, 2010; Farber, 2015). The DWS conveys information unavailable to researchers only using administrative data, such as demographic information, whether notice was given before layoff, whether a jobless displaced worker is searching for employment (i.e. unemployed or not in the labor force) (see Table C.1). ${ }^{24}$

Table C.2 describes the gender and racial composition, average age of layoff, and educational attainment of displaced workers according to the DWS to contextualize our industry heterogeneity analysis in Section 5. Workers displaced from manufacturing, education and health, and public administration are among the oldest, on average, laid off from their jobs. More than half of the workers displaced from construction and mining, food services and hospitality, and manufacturing have only a high school degree or less and have not previously attended college.

Table C.3 compares our Ohio sample to the DWS with respect to workers' industry of displacement. At the broad industrial level (reflecting roughly 1-digit NAICS classification), the sectoral balance of our Ohio displaced worker sample matches the DWS very well. The only difference is our sample has a slightly larger share displaced from manufacturing, perhaps unsurprisingly.

\footnotetext{
${ }^{24}$ All statistics are survey-weighted using "dwsuppwt."
} 
Table C.1: Characteristics from Displaced Worker Supplement

\begin{tabular}{|c|c|c|}
\hline Variable & Displaced 2002-2005 & Displaced 2006-2009 \\
\hline Mean Age at Displacement & 42 & 44 \\
\hline Share Female & 0.45 & 0.41 \\
\hline Share Non-White & 0.17 & 0.17 \\
\hline Share Married & 0.62 & 0.61 \\
\hline \multicolumn{3}{|l|}{ Educational Attainment (time of survey) } \\
\hline$<$ HS Diploma & 0.09 & 0.09 \\
\hline HS Diploma & 0.33 & 0.34 \\
\hline Some College & 0.21 & 0.20 \\
\hline Assoc./Bach. Deg or More & 0.37 & 0.36 \\
\hline \multicolumn{3}{|l|}{ Layoff-Related Characteristics } \\
\hline Mean Years Worked at Lost Job & 9 & 9 \\
\hline Plant Closed Down/Moved & 0.44 & 0.32 \\
\hline Worked Full-Time at Lost Job & 0.90 & 0.88 \\
\hline Received UI Benefits & 0.55 & 0.56 \\
\hline \multicolumn{3}{|l|}{ Notice Given Before Displacement } \\
\hline None Given & 0.56 & 0.61 \\
\hline$<1$ Month & 0.10 & 0.12 \\
\hline 1-2 Months & 0.15 & 0.13 \\
\hline$>2$ Months & 0.17 & 0.12 \\
\hline \multicolumn{3}{|l|}{ Employment Status at Time of Survey } \\
\hline Employed & 0.63 & 0.51 \\
\hline Unemployed & 0.22 & 0.35 \\
\hline Not in Labor Force: Retired/Disabled & 0.05 & 0.05 \\
\hline Not in Labor Force: Other & 0.11 & 0.10 \\
\hline \multicolumn{3}{|l|}{ Share by Industry of Layoff } \\
\hline Manufacturing & 0.28 & 0.23 \\
\hline Construction, Mining & 0.08 & 0.13 \\
\hline Utilities & 0.01 & 0.00 \\
\hline Retail & 0.10 & 0.11 \\
\hline Finance, Insurance, Real Estate & 0.09 & 0.09 \\
\hline Transportation & 0.04 & 0.04 \\
\hline Education \& Health & 0.10 & 0.10 \\
\hline Food \& Hospitality & 0.04 & 0.04 \\
\hline Wholesale & 0.04 & 0.04 \\
\hline Public Administration & 0.01 & 0.01 \\
\hline Professional, Scientific, Technical & 0.07 & 0.07 \\
\hline Administrative, Support, Waste Manage & 0.04 & 0.03 \\
\hline$N$ & 2,596 & 3,261 \\
\hline
\end{tabular}

Source: IPUMS-CPS Displaced Worker Supplement, www.ipums.org. Note: Sample includes civilians age 20 + who lost their job, had at least three years tenure, and were not self-employed at the time of the survey. The first (second) column corresponds to the 2004 and 2006 (2008 and 2010) DWS waves. 
Table C.2: Displaced Worker Demographics by Industry of Layoff from DWS

\begin{tabular}{lcccccc}
\hline Layoff Industry & Age & Female & Nonwhite & HS or Less & Some College & Degree \\
\hline Manufacturing & 44 & 0.38 & 0.17 & 0.56 & 0.18 & 0.26 \\
Construction, Mining & 39 & 0.11 & 0.12 & 0.61 & 0.17 & 0.23 \\
Utilities & 40 & 0.15 & 0.00 & 0.20 & 0.10 & 0.70 \\
Retail & 42 & 0.54 & 0.12 & 0.43 & 0.23 & 0.35 \\
Finance, Insurance, Real Estate & 43 & 0.59 & 0.25 & 0.28 & 0.20 & 0.52 \\
Transportation & 42 & 0.19 & 0.12 & 0.41 & 0.27 & 0.32 \\
Education \& Health & 45 & 0.78 & 0.20 & 0.24 & 0.27 & 0.48 \\
Food \& Hospitality & 37 & 0.52 & 0.16 & 0.56 & 0.24 & 0.21 \\
Wholesale & 41 & 0.30 & 0.12 & 0.34 & 0.24 & 0.42 \\
Public Administration & 45 & 0.33 & 0.17 & 0.16 & 0.27 & 0.57 \\
Professional, Scientific, Technical & 42 & 0.52 & 0.15 & 0.13 & 0.19 & 0.68 \\
Administrative, Support, Waste Mgmt & 42 & 0.57 & 0.28 & 0.48 & 0.20 & 0.33 \\
\hline \hline
\end{tabular}

Source: IPUMS-CPS Displaced Worker Supplement, www.ipums.org. Note: Sample includes civilians age 20+ who lost their job, had at least three years tenure, and were not self-employed at the time of the survey. Workers were displaced between 2002 and 2005 (corresponding to the DWS 2004 and 2006 waves, restricting to workers displaced in the last two years). Sample is weighted using "dwsuppwt." Age column represents mean age at layoff.

Table C.3: Displaced Worker Industry Comparison: Ohio sample and DWS

\begin{tabular}{lcc}
\hline Industry of Layoff & Minaya, Moore, Scott-Clayton & DWS (displaced 2002-2009) \\
\hline Manufacturing & 0.29 & 0.25 \\
Construction, Utilities, Mining & 0.11 & 0.11 \\
Retail Trade & 0.11 & 0.10 \\
Transportation \& Warehousing & 0.08 & 0.04 \\
Education \& Health & 0.07 & 0.10 \\
Food Services \& Hospitality & 0.05 & 0.04 \\
Other & 0.22 & 0.27 \\
$N$ & 68,547 & 5,857 \\
\hline \hline
\end{tabular}

Note: Left column reflects the Ohio administrative sample displaced between 2002 and 2009 (Table 1). Right reflects national respondents of the DWS displaced during the same time period (2004-2010 waves of the DWS). "Other" industries include Wholesale, Public Administration, Professional, Scientific, and Technical Services, and Administrative, Support, and Waste Management. 